Award Number: DAMD17-02-1-0216

TITLE: EGFR-Dependent Regulation of Matrix-Independent Epithelial Cell Survival

PRINCIPAL INVESTIGATOR: Ulrich Rodeck, M.D.

CONTRACTING ORGANIZATION: Thomas Jefferson University

Philadelphia, PA 19107

REPORT DATE: April 2006

TYPE OF REPORT: Final

PREPARED FOR: U.S. Army Medical Research and Materiel Command Fort Detrick, Maryland 21702-5012

DISTRIBUTION STATEMENT: Approved for Public Release;

Distribution Unlimited

The views, opinions and/or findings contained in this report are those of the author(s) and should not be construed as an official Department of the Army position, policy or decision unless so designated by other documentation. 


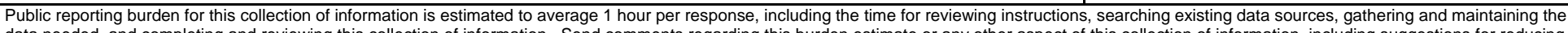

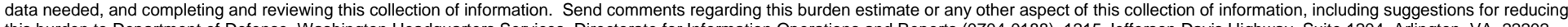

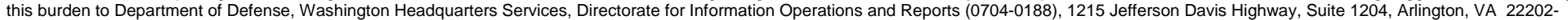

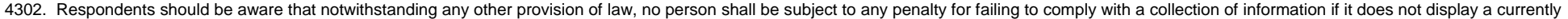
valid OMB control number. PLEASE DO NOT RETURN YOUR FORM TO THE ABOVE ADDRESS.
1. REPORT DATE (DD-MM-YYYY)
2. REPORT TYPE
3. DATES COVERED (From - To)

01-04-2006

Final

4. TITLE AND SUBTITLE

EGFR-Dependent Regulation of Matrix-Independent Epithelial Cell Survival

15 Mar 2002 - 14 Mar 2006

5a. CONTRACT NUMBER

5b. GRANT NUMBER

DAMD17-02-1-0216

5c. PROGRAM ELEMENT NUMBER

6. AUTHOR(S)

Ulrich Rodeck, M.D.

E-Mail: Ulrich.Rodeck@jefferson.edu

7. PERFORMING ORGANIZATION NAME(S) AND ADDRESS(ES)

Thomas Jefferson University

Philadelphia, PA 19107 5d. PROJECT NUMBER

5e. TASK NUMBER

5f. WORK UNIT NUMBER

8. PERFORMING ORGANIZATION REPORT NUMBER

10. SPONSOR/MONITOR'S ACRONYM(S)

U.S. Army Medical Research and Materiel Command

Fort Detrick, Maryland 21702-5012

11. SPONSOR/MONITOR'S REPORT NUMBER(S)

12. DISTRIBUTION I AVAILABILITY STATEMENT

Approved for Public Release; Distribution Unlimited

\section{SUPPLEMENTARY NOTES}

Original contains colored plates: ALL DTIC reproductions will be in black and white.

\section{ABSTRACT:}

Background: Signaling through the epidermal growth factor (EGFR) has been implicated in both effective wound healing and epithelial neoplasia. We have identified a novel function of the EGFR in support of epithelial cell survival, particularly in conditions of anchorage-independence. Objective/Hypothesis: Define molecular mechanisms and pathways by which EGFR activation supports epithelial cell survival. Two specific aims focus on (1) posttranslational modification of relevant Bcl-2 family members by EGFR activation through MAPK-dependent mechanisms and, (2) STAT3 activation by deregulated EGFR signaling as observed in epithelial cancer. Progress: Significant progress relating to Specific Aim 1 has included: Publication of results in support of BIM regulation by the EGFR in normal and transformed keratinocytes (Appendices included); Characterization of a role of NF-KB activation in keratinocyte survival in the absence of extracellular matrix interaction; and Pro-apoptotic signals by JNK and p38 activation in the anchorage-independent state are counteracted by NF-KB activity. We have completed the work proposed in Specific Aim 2.

\section{SUBJECT TERMS}

Receptor; Epidermal Growth Factor; Cell Survival; Cell Transformation; Neoplastic; Mitogenactivated Protein Kinases

\begin{tabular}{|c|c|c|c|c|c|}
\hline \multicolumn{3}{|c|}{ 16. SECURITY CLASSIFICATION OF: } & \multirow{2}{*}{$\begin{array}{l}\text { 17. LIMITATION } \\
\text { OF ABSTRACT } \\
\text { UU }\end{array}$} & \multirow{2}{*}{$\begin{array}{l}\text { 18. NUMBER } \\
\text { OF PAGES } \\
32\end{array}$} & \multirow{2}{*}{$\begin{array}{l}\text { 19a. NAME OF RESPONSIBLE PERSON } \\
\text { USAMRMC } \\
\text { 19b. TELEPHONE NUMBER (include area } \\
\text { code) }\end{array}$} \\
\hline $\begin{array}{r}\text { a. REPORT } \\
U\end{array}$ & $\begin{array}{c}\text { b. ABSTRACT } \\
U\end{array}$ & $\begin{array}{c}\text { c. THIS PAGE } \\
U\end{array}$ & & & \\
\hline
\end{tabular}


Table of Contents

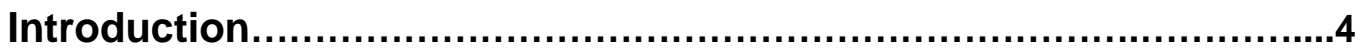

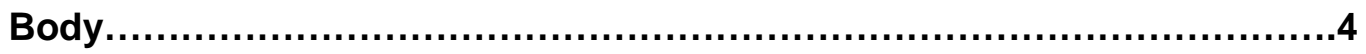

Key Research Accomplishments............................................

Reportable Outcomes.......................................................

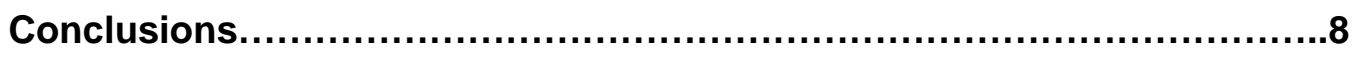

References......................................................................

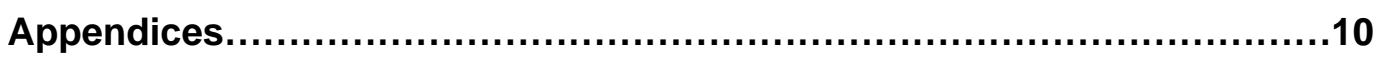




\section{INTRODUCTION}

The epidermal growth factor receptor (EGFR) is a type-1 receptor tyrosine kinase. Activation of the EGFR has been implicated in many aspects of cell biology pertaining to wound healing and malignant transformation of epithelial cells. Previous work from our laboratory underscored a novel function of the EGFR in support of cell survival of epidermal keratinocytes. Specifically, EGFR activation and signaling was observed to protect keratinocytes against induction of apoptosis through extracellular stressors $(1,2)$. The major thrust of the research funded through DAMD17-02-1-0216 was to further characterize the protective role of EGFR activation in situations in which keratinocytes encounter suboptimal extracellular matrix interaction, i.e. during wound healing and metastatic spread of malignant cells. We originally proposed to pursue two specific aspects of EGFR activation as they relate to cell survival. Specific Aim 1 focused on posttranslational modifications of regulators of cell survival of the Bcl-2 family of molecules through EGFR activation and suspension culture. Specific Aim 2 dealt with the question whether inappropriate signaling through the EGFR as observed in cancer cells leads to aberrant STAT3 activation, which in turn enhances cell survival.

\section{BODY}

This progress report will focus on accomplishments relating to Specific Aims 1 of the original proposal as we have made significant progress in this area. The objectives of Specific Aim 2 have been achieved during the first 2 year of support and published as outlined in our previous progress report.

Specific Aim 1

We have published the manuscript 'EGFR-dependent downregulation of Bim in epithelial cells requires MAPK and PKC- activities' by Quadros, M.A., Connelly, S., Kari, C., Abrams, M.A., Wickstrom, E., and Rodeck. U. in Cancer Biology and Therapy 5:498-504, 2006. In this work we evaluated posttranslational modification of the proapoptotic Bcl-2 family member Bim during suspension culture and in the presence and absence of EGFR activation in HaCaT keratinocytes. The results can be summarized as follows:

- Activation of the epidermal growth factor receptor (EGFR) provides a measure of protection to immortalized epidermal keratinocytes (HaCaT cells) against apoptosis induced by diverse cellular stressors. This effect is due, in part, to sustained MAPK-dependent Bcl-xL expression.

- We identified a second EGFR/MAPK-dependent signaling event that protects $\mathrm{HaCaT}$ cells against apoptosis incurred during forced suspension culture (anoikis). This pathway targets Bim, a pro-apoptotic BH3-only Bcl-2 family member.

- Bim expression was functionally relevant to HaCaT cell survival as demonstrated by partial protection against anoikis provided by siRNA-induced Bim downregulation (see Fig. 1 in manuscript \#1 attached). 
- Growth factor starvation of attached and suspended cells was associated with enhanced Bim expression whereas EGFR activation reduced Bim expression by inducing Bim phosphorylation and proteasomal degradation (see Figs. 2 and 4 in manuscript \#1 attached).

- EGFR-dependent Bim phosphorylation required MAPK activation. Furthermore, PKC- $\delta$ activity contributed to both MEK/MAPK phosphorylation and Bim phosphorylation as demonstrated using both pharmacological inhibitors of PKC- $\delta$ and siRNA-mediated PKC- $\delta$ knockdown (see Fig. 5 in manuscript \#1 attached)..

- In addition to HaCaT cells, EGFR activation supported survival and induced Bim phosphorylation in several squamous carcinoma cell lines in a strictly MAPKdependent fashion (see Fig. 6 and 7 in manuscript \#1 attached)..

- These results establish that EGFR activation attenuates susceptibility of immortalized and malignant keratinocytes to apoptosis by posttranslational control of Bim-EL expression through a pathway requiring PKC- $\delta$ and MEK/MAPK activation.

A second manuscript mentioned in the previous progress report was also published: ' $A$ novel role for $E$-cadherin loss during initiation of squamous cell carcinoma through modulation of integrin-mediated matrix adhesion' by Zhang, W., Alt-Holland, A., Margulis, A., Rodeck, U., Fusenig, N.E., and Garlick, J.A; J. Cell Science 119:283-92, 2006.

- Novel 3D human tissue constructs that mimic premalignant disease in normal epidermis were used to directly investigate how loss of E-cadherin directs conversion to malignant disease.

- A genetically tagged variant of Ha-Ras-transformed human keratinocytes expressing dominant-interfering (DI) E-cadherin was used.

- DI-E-cadherin expressing cells persisted at the basement membrane zone of skin reconstructs enabling tumor cell invasion upon transplantation to mice ((see Figs. 1 - 3 in manuscript \#2 attached).

- DI-E-cadherin cells expressed increased levels of alpha2, alpha3, and beta1 integrins and increased adhesion to basement membrane components laminin-1 and types I and IV collagen (see Figs. 4 and 5 in manuscript \#2 attached)..

- These results establish a novel aspect of E-cadherin function as it realtes to cellmatrix adhesion.

This work has led to a joint grant application to the NIH focusing on the cross-talk of EGFR and E-cadherin as it relates to keratinocyte survival and malignant transformation.

A third manuscript with direct relevance to the survival phenotype of human keratinocytes in the anchorage-independent state was published: 'Malignant transformation of immortalized HaCaT keratinocytes through deregulated $\mathrm{NF}-\kappa \mathrm{B}$ signaling' by Ren, Q., Kari, C., Quadros, M.R., Burd, R., McCue, P., Dicker, A.P., and Rodeck, U.; Cancer Res. 66: 5209-15. This work expands the scope of cell survival mechanisms in epidermal keratinocytes beyond the EGF receptor. Specifically, it provides evidence that: 
- specific matrix components protected human immortalized keratinocytes (HaCaT) against apoptosis induced by blockade of either the epidermal growth factor receptor (EGFR) or MEK or PI3-kinase (see Fig. 3 in manuscript \#3 attached)..

- In contrast, nuclear factor NFאB activation was indispensable to HaCaT cell survival regardless of matrix availability (see Figs. 1 and 2 in manuscript \#3 attached).

- Conversely, tumor necrosis factor (TNF)- $\alpha$ supported anchorage-independent survival of HaCaT cells in an NFkB-dependent fashion (see Fig. 5 in manuscript \#3 attached).

- Deregulated NF-kB signaling by overexpression of the NF-kB p65 subunit converts immortalized HaCaT keratinocytes to fully malignant, tumorigenic cells (see Fig. 6 in manuscript \#3 attached).

These results highlight previously unrecognized patterns of signal integration between survival pathways relevant to wound healing and malignant transformation of the skin in that NF-kB signaling and EGFR signaling cooperatively induce anchorage-independent keratinocyte survival. This work has direct translational relevance as upregulation of NF$\kappa \mathrm{B}$ signaling in wound healing may provide a second therapeutic approach in addition to stimulating EGFR activation. This work further provides the basis for a grant application to NIH to further dissect NF- $\mathrm{BB}$ signaling in keratinocyte survival with a particular focus on the interplay of NF-kB signaling with JNK/SAPKinases (see below).

To conclude the proposed studies, we are currently pressing ahead with the work on MAPkinases JNK and p38 in the anchorage-independent state. As described in the previous progress report we noticed strong JNK/p38 phosphorylation in suspension culture, which was only marginally affected by EGFR activation. We decided to evaluate the relevance of these two MAPKs to keratinocyte death in forced suspension culture based on previous reports that they exert pro- or anti-apoptotic effects in different cell systems and experimental settings (3-7). We observed that pharmacological inhibition of JNK but not p38 moderately attenuates apoptosis of keratinocytes in the anchorageindependent state. We are now defining the role of NF- $\mathrm{KB}$ in counteracting pro-apoptotic $\mathrm{JNK}$ and/or p38 activity in the anchorage-independent state. This is based on previous reports that sustained JNK activation contributes to apoptosis when NF- $\kappa \mathrm{B}$ activation is blocked $(8,9)$. Collectively, these studies highlight complex roles and regulation of MAPkinases in keratinocyte apoptosis resistance. Whereas EGFR-dependent MAPK activation protects keratinocytes, JNK and p38 activation appear to exert pro-apoptotic effects. However, these can be counteracted by NF-кB activation.

Specific Aim 2

As outlined in the previous progress report we have completed the work proposed in Specific Aim 2.

Finally, Dr. Rodeck participated in the PRMRP meeting for DOD grantees in April 2006 in San Juan, Puerto Rico and presented a poster focusing on the characterization of a 
novel radiation protector based on the nanoparticle DF-1 (C-Sixty Inc.) in a novel in vivo vertebrate systen (zebrafish embryos). This work has been conditionally accepted for publication in Clinical Cancer Research (Daroczi, B., Kari, G., McAleer, M.F., Rodeck,

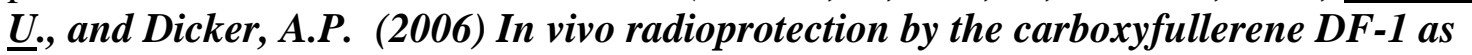
assessed in a zebrafish model). Although not directly supported by DAMD17-02-102156 this work has military relevance to prevent radiation-induced morbidity and mortality in the war fighter as well as the civilian population.

\section{KEY RESEARCH ACCOMPLISHMENTS}

- Identification of the pro-apoptotic Bcl-2 family member Bim as a target of the EGFR/MAPK signaling axis in normal and transformed keratinocytes;

- Demonstration that Bim regulation occurs by posttranslational modification (phosphorylation) targeting BIM for proteasomal degradation;

- Identification of alpha2, alpha3, and beta1 integrins as targets for E-cadherin signaling with implications for enhanced matrix interaction and tumorigenicity;

- Characterization of a role of NF-кB activation in keratinocyte survival in the absence of extracellular matrix interaction;

- Demonstration that NF-кB and EGFR signaling occur independently to support anchorage-independent survival of immortalized keratinocytes;

- Pro-apoptotic signals by JNK and p38 activation in the anchorage-independent

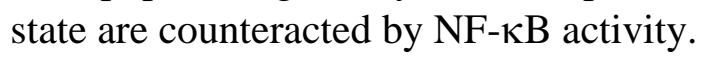

Collectively, these findings support the concept of complex regulation of enhanced keratinocyte survival during wound healing and cancer in which the EGFR plays a major role which is complemented by alterations of cell-cell adhesion molecules (E-cadherin) and of the NF-кB pathway. The relevance of these findings relates to the design of combination therapies targeting the EGFR as well as NF- $\kappa \mathrm{B}$ to disrupt skin tumorigenesis. Conversely, pharmacological EGFR activation and stimulation of NF- $\kappa \mathrm{B}$ activation could be considered in the context of acceleration of wound healing.

\section{REPORTABLE OUTCOMES}

During the last year 3 peer-reviewed manuscripts directly supported by DAMD17-02-10216 were published as summarized above.

Manuscript \#1:

Quadros, M.A., Connelly, S., Kari, C., Abrams, M.A., Wickstrom, E., and Rodeck. U EGFR-dependent downregulation of Bim in epithelial cells requires MAPK and PKCactivities. Cancer Biology and Therapy 5:498-504, 2006.

Manuscript \#2: 
Zhang, W., Alt-Holland, A., Margulis, A., Rodeck, U., Fusenig, N.E., and Garlick, J.A A novel role for $E$-cadherin loss during initiation of squamous cell carcinoma through modulation of integrin-mediated matrix adhesion. J. Cell Science 119:283-92, 2006

\section{Manuscript \#3:}

Ren, Q., Kari, C., Quadros, M.R., Burd, R., McCue, P., Dicker, A.P., and Rodeck, U. Malignant transformation of immortalized HaCaT keratinocytes through deregulated NF- KB signaling. Cancer Res. 66: 5209-15.

PDFs of the published manuscripts are appended to this report and contain multiple visual representations of the results described above and referenced in the Body section as appropriate.

\section{CONCLUSIONS}

During 48 months of funding we have largely accomplished the objectives laid out in Specific Aims 1and 2 of the original proposal. Presently, we are in the process of completing studies on attenuation of JNK/SAPkinase-mediated cell death through an NF$\kappa \mathrm{B}$-dependent pathway. These are studies directly related to the original aims of the proposal and will provide further insights into complex regulatory mechanisms in support of keratinocyte survival during the wound healing process and in advanced stages of malignancy. 


\section{REFERENCES}

1. Kari, C., Chan, T. O., Rocha de Quadros, M., and Rodeck, U. Targeting the epidermal growth factor receptor in cancer: apoptosis takes center stage. Cancer Res, 63: 1-5, 2003.

2. Rodeck, U., Jost, M., Kari, C., Shih, D. T., Lavker, R. M., Ewert, D. L., and Jensen, P. J. EGF-R dependent regulation of keratinocyte survival. J Cell Sci, 110: 113-121, 1997.

3. $\quad$ Fuchs, S. Y., Adler, V., Pincus, M. R., and Ronai, Z. MEKK1/JNK signaling stabilizes and activates p53. Proc Natl Acad Sci (United States of America), 95: 10541-10546, 1998.

4. $\quad$ Cardone, M. H., Salvesen, G. S., Widmann, C., Johnson, G., and Frisch, S. M. The regulation of anoikis: MEKK-1 activation requires cleavage by caspases. Cell, 90: 315-323, 1997.

5. Antonyak, M. A., Moscatello, D. K., and Wong, A. J. Constitutive activation of cJun N-terminal kinase by a mutant epidermal growth factor receptor. J Biol Chem, 273: 2817-2822, 1998.

6. Smith, A., Ramos-Morales, F., Ashworth, A., and Collins, M. A role for JNK/SAPK in proliferation, but not apoptosis, of IL-3-dependent cells. Curr Biol, 7: 893-896, 1997.

7. $\quad$ Assefa, Z., Vantieghem, A., Declercq, W., Vandenabeele, P., Vandenheede, J. R., Merlevede, W., de Witte, P., and Agostinis, P. The activation of the c-Jun Nterminal kinase and p38 mitogen-activated protein kinase signaling pathways protects HeLa cells from apoptosis following photodynamic therapy with hypericin. J Biol Chem, 274: 8788-8796, 1999.

8. Tang, G., Minemoto, Y., Dibling, B., Purcell, N. H., Li, Z., Karin, M., and Lin, A. Inhibition of JNK activation through NF-kappaB target genes. Nature, 414: 313317, 2001.

9. $\quad$ Tang, F., Tang, G., Xiang, J., Dai, Q., Rosner, M. R., and Lin, A. The absence of NF-kappaB-mediated inhibition of c-Jun N-terminal kinase activation contributes to tumor necrosis factor alpha-induced apoptosis. Mol Cell Biol, 22: 8571-8579, 2002. 


\title{
E-cadherin loss promotes the initiation of squamous cell carcinoma invasion through modulation of integrin-mediated adhesion
}

\author{
Weitian Zhang ${ }^{1, \star}$, Addy Alt-Holland ${ }^{1, \star}$, Alexander Margulis ${ }^{1}$, Yulia Shamis ${ }^{1}$, Norbert E. Fusenig ${ }^{2}$, \\ Ulrich Rodeck ${ }^{3}$ and Jonathan A. Garlick ${ }^{1, \neq}$ \\ ${ }^{1}$ Division of Cancer Biology and Tissue Engineering, Department of Oral and Maxillofacial Pathology, School of Dental Medicine, Tufts University, \\ 55 Kneeland Street, Boston, MA 02111, USA \\ ${ }^{2}$ German Cancer Research Center, Im Neuenheimer Feld 280, 69120 Heidelberg, Germany \\ ${ }^{3}$ Department of Dermatology and Cutaneous Biology, Thomas Jefferson University, 233 South 10th Street, Philadelphia, PA 19107, USA \\ ${ }^{*}$ These authors contributed equally to this work \\ ${ }^{\ddagger}$ Author for correspondence (e-mail: jonathan.garlick@tufts.edu)
}

Accepted 5 October 2005

Journal of Cell Science 119, 283-291 Published by The Company of Biologists 2006

doi:10.1242/jcs.02738

\section{Summary}

Much remains to be learned about how cell-cell and cellmatrix interactions are coordinated to influence the earliest development of neoplasia. We used novel 3D human tissue reconstructs that mimic premalignant disease in normal epidermis, to directly investigate how loss of E-cadherin function directs conversion to malignant disease. We used a genetically tagged variant of Ha-Ras-transformed human keratinocytes (II-4) expressing dominant-interfering Ecadherin fusion protein $\left(\mathbf{H}-2 \mathbf{k}^{\mathrm{d}}\right.$-Ecad). These cells were admixed with normal human keratinocytes and tumor cell fate was monitored in 3D reconstructed epidermis upon transplantation to immunodeficient mice. Tumor initiation was suppressed in tissues harboring controland mock-infected II-4 cells that lost contact with the stromal interface. By contrast, $\mathbf{H}-2 \mathrm{k}^{\mathrm{d}}$-Ecad-expressing cells

\section{Introduction}

Cell fate decisions in whole organisms are largely controlled by signals imparted by the tissue microenvironment. This occurs through a complex network of molecular signals that is directed either by interactions between neighboring cells or with extracellular matrix components or by stimulation of cell surface receptors by soluble factors. This multitude of environmental signals provides an efficient system to control cell behavior and maintain tissue homeostasis. Conversely, cancer development may be considered as a breakdown of microenvironmental control of cell behavior (Bissell and Radisky, 2001). Consistent with this notion, both integrinmediated cell-matrix adhesion and cadherin-mediated cellcell adhesion are frequently altered in tumor cells as a result of loss or gain of specific adhesion receptors. For example, the cell-cell adhesion receptor E-cadherin is frequently lost during advanced stages of epithelial cancer progression (Perl et al., 1998; Birchmeier and Behrens, 1994) and this is considered to be an important step in invasion and metastasis of epithelial tumor cells (Bissell and Radisky, 2001; Cavallaro and Cristofori, 2004; Cano et al., 2000). However, it is not well understood how perturbation of cell adhesion networks can influence the initial stages of persisted at this interface, thus enabling incipient tumor cell invasion upon in vivo transplantation. Loss of intercellular adhesion was linked to elevated cell surface expression of $\alpha 2, \alpha 3$ and $\beta 1$ integrins and increased adhesion to laminin- 1 and Types $I$ and IV collagen that was blocked with $\beta 1$-integrin antibodies, suggesting that invasion was linked to initial II-4 cell attachment at the stromal interface. Collectively, these results outline a novel aspect to loss of E-cadherin function that is linked to the mutually interdependent regulation of cell-cell and cellmatrix adhesion and has significant consequences for the conversion of premalignancy to cancer.

Key words: E-cadherin, Integrin, Squamous cell carcinoma, 3D cultures, Premalignant

cancer progression as premalignant-to-malignant conversion occurs.

A complex epithelium such as the epidermis provides a model system that is well suited to study the networks of structural and contextual signals that govern the orderly execution of normal proliferation and differentiation programs (Jamora and Fuchs, 2002). During the earliest, intraepithelial stages of squamous cell carcinoma development, small nests of aberrant, dysplastic tumor cells are exposed to and affected by the same positional signals that govern normal epithelial cell behavior (Dlugosz et al., 2002). To better understand this interplay we have developed three-dimensional (3D) human tissue models that allow us to monitor premalignant, intraepithelial (IE) stages of squamous carcinoma progression in the context of an in-vivo-like stratified epithelium (AltHolland et al., 2005). We described previously that interactions between IE tumor cells and neighboring normal cells can lead to suppression of early neoplastic progression by inducing a state of 'intraepithelial dormancy' (Javaherian et al., 1998). This dormant state could be overcome by altered tissue dynamics in response to the tumor promoter TPA (Karen et al., 1999), ultraviolet (UV) irradiation (Mudgil et al., 2003), decreased adhesive interactions between tumor cells and adjacent epithelia 
(Vaccariello et al., 1999) or by enabling tumor cells to interact with basement membrane (BM) proteins (Andriani et al., 2004). These observations implied that alterations in the ability of IE tumor cells to adhere to adjacent cells or in their capacity to persist at the stromal interface were of crucial importance to their invasive potential. Concurrently, other studies performed in conventional two-dimensional (2D) cultures, provided evidence for mutual interdependence between cadherin- and integrin-mediated adhesion events in cancer cells (Avizienyte et al., 2002; Zhang et al., 2003; Yano et al., 2004). However, the functional consequences of such crosstalk between these distinct adhesive pathways during the earliest stages of cancer development in 3D tissues or in vivo remain largely unknown.

The present study provides new insights into the dynamic equilibrium between cell-cell and cell-matrix adhesive events in early epithelial tumor progression. Specifically, ablation of Ecadherin function in cells with malignant potential imparted an invasive phenotype to these cells by allowing them to overcome microenvironmental constraints on their progression. This phenomenon was associated with retention of E-cadherindeficient cells at the epithelial-stromal interface in epidermal reconstructs. Furthermore, increased retention at this interface co-segregated with enhanced adhesion of E-cadherin-deficient cells to extracellular matrix components including laminin, fibronectin and Type IV collagen in vitro. Finally, we describe increased expression of integrin subunits likely to mediate adhesion in E-cadherin-deficient cells to collagen Types I and IV at this interface. Collectively, our results point to a novel aspect of E-cadherin loss in epithelial tumor progression that is not only related to severing cell-cell adhesion but also is associated with increased cell-matrix adhesion of these cells. The functional consequence of enhanced cell-matrix adhesion is the initial attachment and retention of these cells at the epithelial-stromal interface, thus providing the appropriate microenvironmental conditions for incipient tumor cell invasion.

\section{Results}

Loss of E-cadherin enables premalignant-to-malignant conversion upon incipient tumor cell invasion

Our previous studies showed that II-4 cells were nontumorigenic when placed in epidermal reconstructs with human epidermal keratinocytes (HEK) because of their microenvironmental growth suppression and were shed from the epithelial surface (Javaherian et al., 1998). Based on this earlier observation, we first determined if loss of E-cadherin function could circumvent this constraint by altering the dynamics of II-4 cell behavior when grown in the context of normal, differentiating epidermal cells in $3 \mathrm{D}$ reconstructs. Epidermal reconstructs were established in vitro with either control II-4 cells expressing pBabe or $\mathrm{H}-2 \mathrm{k}^{\mathrm{d}}-\mathrm{EcadC} 25$ or with II-4 cells expressing a dominant-interfering E-cadherin $(\mathrm{H}-$ $2 \mathrm{k}^{\mathrm{d}}$-Ecad). The $\mathrm{H}-2 \mathrm{k}^{\mathrm{d}}$-Ecad transgene has previously been described to interfere with E-cadherin function in normal keratinocytes (Zhu and Watt, 1996) and II-4 cells (Margulis et al. 2005a). This occurs as overexpression of this fusion protein leads to destabilization of endogenous E-cadherin- $\beta$-catenin complexes upon the cytoplasmic sequestration of $\beta$-catenin by the dominant-interfering transgene and to loss of E-cadherinmediated intercellular adhesion. By contrast, the $\mathrm{H}-2 \mathrm{k}^{\mathrm{d}}$ EcadC25 used as a control, lacks the $\beta$-catenin binding region in the intracellular domain of E-cadherin and has no
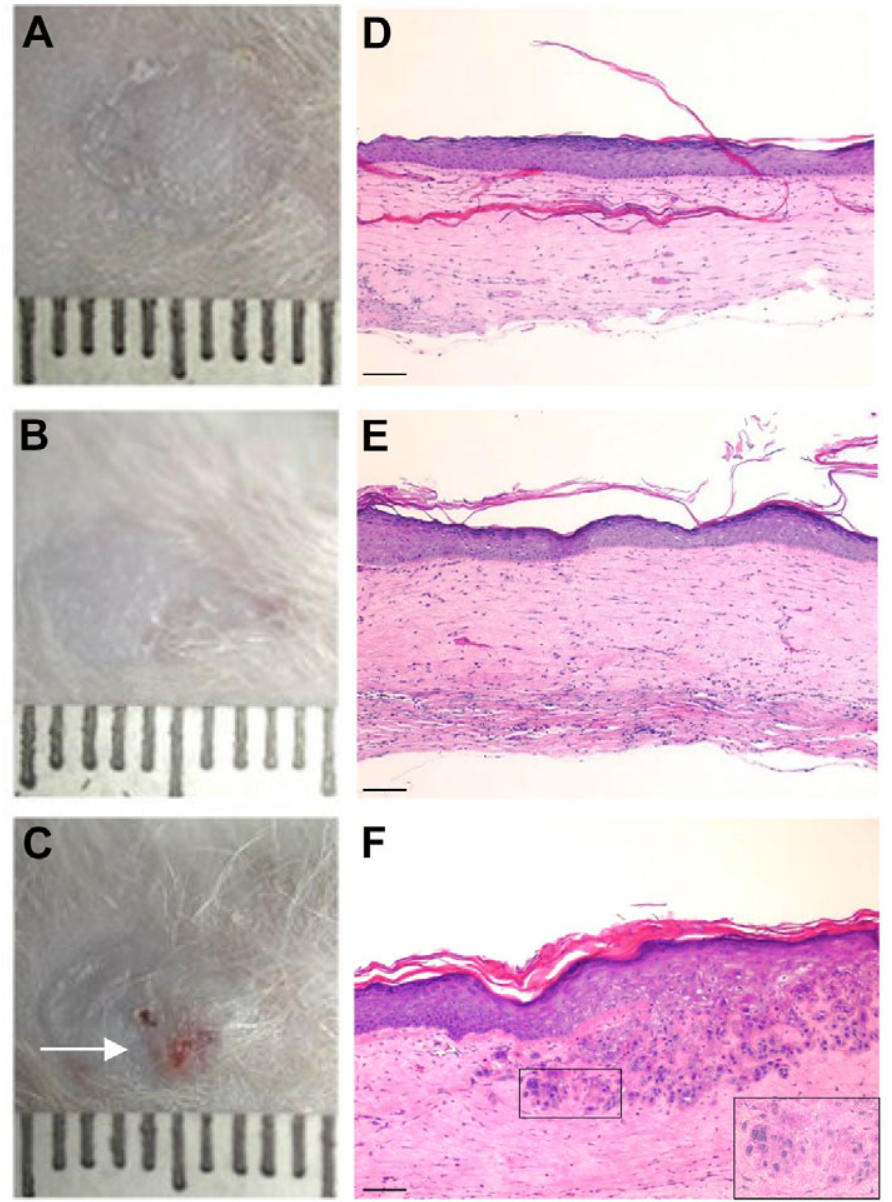

Fig. 1. Invasive tumor formation after in vivo transplantation was dependent upon loss of E-cadherin. (A-C) Clinical appearance of 3D surface transplants (left panel): $3 \mathrm{D}$ tissues were engineered in vitro as 4:1 mixtures of HEK and either pBabe-, $\mathrm{H}-2 \mathrm{k}^{\mathrm{d}}$-EcadC25- or $\mathrm{H}$ $2 \mathrm{k}^{\mathrm{d}}$-Ecad-II-4-expressing cells and transplanted to the dorsum of nude mice for 4 weeks. Grafts harboring E-cadherin-deficient, $\mathrm{H}$ $2 \mathrm{k}^{\mathrm{d}}$-Ecad-expressing II- 4 cells generated nodular tumors with focal areas of erythema (C, arrow). By contrast, grafts containing II-4$\mathrm{pBabe}(\mathrm{A})$ or $\mathrm{H}-2 \mathrm{k}^{\mathrm{d}}$-EcadC25-expressing cells (B) generated normal grafts without any evidence of tumor formation. (D-F) Histological appearance of 3D surface transplants. Tumors generated in transplants of 4:1 mixtures of HEK and $\mathrm{H} 2 \mathrm{k}^{\mathrm{d}}$-Ecad-expressing II-4 cells demonstrated invasion of individual cells ( $F$, inset) and small clusters of poorly differentiated tumor cells $(\mathrm{F})$. By contrast, grafted mixtures of HEK with either pBabe- (D) or H-2 $\mathrm{k}^{\mathrm{d}}$-EcadC25expressing II-4 cells (E) generated normal epithelia without any evidence of residual tumor cells. Bars, $20 \mu \mathrm{m}$.

discernible effect on E-cadherin function. To model a specific IE tumor cell load, HEK were mixed at a 4:1 ratio with II-4 cell variants expressing either of these vectors in 3D tissue constructs and were transplanted as surface grafts to the dorsum of nude mice for 4 weeks. Upon transplantation, only grafts containing HEK/H-2 $\mathrm{k}^{\mathrm{d}}$-Ecad II-4 mixtures generated clinically apparent lesions (Fig. 1C) whereas reconstructs harboring pBabe and $\mathrm{H}-2 \mathrm{k}^{\mathrm{d}}$-Ecad-C25 gave rise to normal human epidermis (Fig. 1A,B respectively). HEK/H-2k ${ }^{\mathrm{d}}$-EcadII-4 mixtures gave rise to raised, nodular lesions with focal areas of erythema (Fig. 1C, arrow). H-2 $\mathrm{k}^{\mathrm{d}}$-Ecad-II-4 tumor 
cells invaded into the dermis as small clusters or as individual cells (Fig. 1F, inset). By contrast, mixtures of control HEK/pBabe-II-4 (Fig. 1A,D) or HEK/H-2k $\mathrm{k}^{\mathrm{d}}$ EcadC25-II4 (Fig. 1B,E) generated normal epidermal grafts with intact epithelial architecture in which no tumor cells were visible. The fate and phenotype of $\mathrm{H}-2 \mathrm{k}^{\mathrm{d}}$-Ecadexpressing II-4 cells was further studied by double immunostaining for the $\beta$-gal marker gene and $\beta$-catenin to determine that transgene expression was maintained in vivo and led to loss of adherens junctions from cell-cell borders (Fig. 2). $\beta$-gal-positive II-4 cells were absent from tissues that originally harbored mixtures of HEK with either the control pBabe- (Fig. 2A) or H-2k $\mathrm{k}^{\mathrm{d}}-$ EcadC25expressing II-4 cells (Fig. 2B). In these transplants, $\beta$ catenin was detected only at cell-cell borders of HEK (Fig. $2 \mathrm{~A}, \mathrm{~B})$. By contrast, large groups of $\beta$-gal-positive, II-4 cells were apparent beneath the dermal/epidermal junction in HEK/H-2 $\mathrm{k}^{\mathrm{d}}$-Ecad-II-4 grafts (Fig. 2C) indicating that these cells had traversed the BM and had invaded into the dermal compartment. Furthermore, these grafts showed cytoplasmic localization of $\beta$-gal (Fig. 2C) and $\beta$-catenin (Fig. 2D) in tumor cells indicating that loss of E-cadherin function was associated with redistribution of $\beta$-catenin from cell junctions in invading cells. Moreover, the majority of large groups of invading $\beta$-gal-positive tumor cells localized beneath the dermal/epidermal junction presented increased expression of the $\alpha 2$ integrin subunit (Fig. 2E). By contrast, in transplants that originally harbored the mixture of HEK with either the control pBabe (Fig. 2F) or $\mathrm{H}-2 \mathrm{k}^{\mathrm{d}}$-EcadC25-expressing II-4 cells (not shown), $\alpha 2$ integrin expression was restricted only to the basal HEK that were layered on the epithelial-stromal interface. This suggested that altered integrin-mediated adhesion may play a role in the invasive properties of these tumor cells. In summary, these results underscore that invasion of II-4 cells was contingent upon loss of Ecadherin function and required the capacity of these cells to persist in the tissue despite loss of adhesion with adjacent cells. This result raised the question as to how $\mathrm{H}-$ $2 \mathrm{k}^{\mathrm{d}}$-Ecad-II-4 cells were retained at the BM interface as a precondition for tumor cell invasion.

\section{Loss of E-cadherin function enhances attachment of} II-4 cells to the epithelial-stromal interface and is a prerequisite for tumor cell invasion

To address this issue, we assessed the distribution of II-4 cell variants in cell mixtures in $3 \mathrm{D}$ in vitro constructs just prior to transplantation. Mixtures of HEK with any of the three types of II-4 cells were cultured at 4:1 ratios at an air-liquid interface for 7 days. The distribution of tumor cells in reconstructs was then analyzed by double immunofluorescent staining for $\beta$-gal and Type IV collagen to identify the II-4 cells and the BM interface, respectively. Reconstructs harboring $\mathrm{H}-2 \mathrm{k}^{\mathrm{d}}$-Ecad-expressing cells demonstrated individual $\beta$-gal-positive, II-4 cells in the basal layer of the epithelium, adjacent to Type IV collagen seen at the epithelial-stromal interface (Fig. 3C, arrow). By contrast, no $\beta$-gal-positive cells were seen at this interface in tissues containing the HEK/pBabe-II-4 (Fig. 3A) or HEK/H$2 \mathrm{k}^{\mathrm{d}}$ EcadC25-II-4 mixtures (Fig. 3B). Consistent with their eventual loss by shedding from the epithelial surface, these
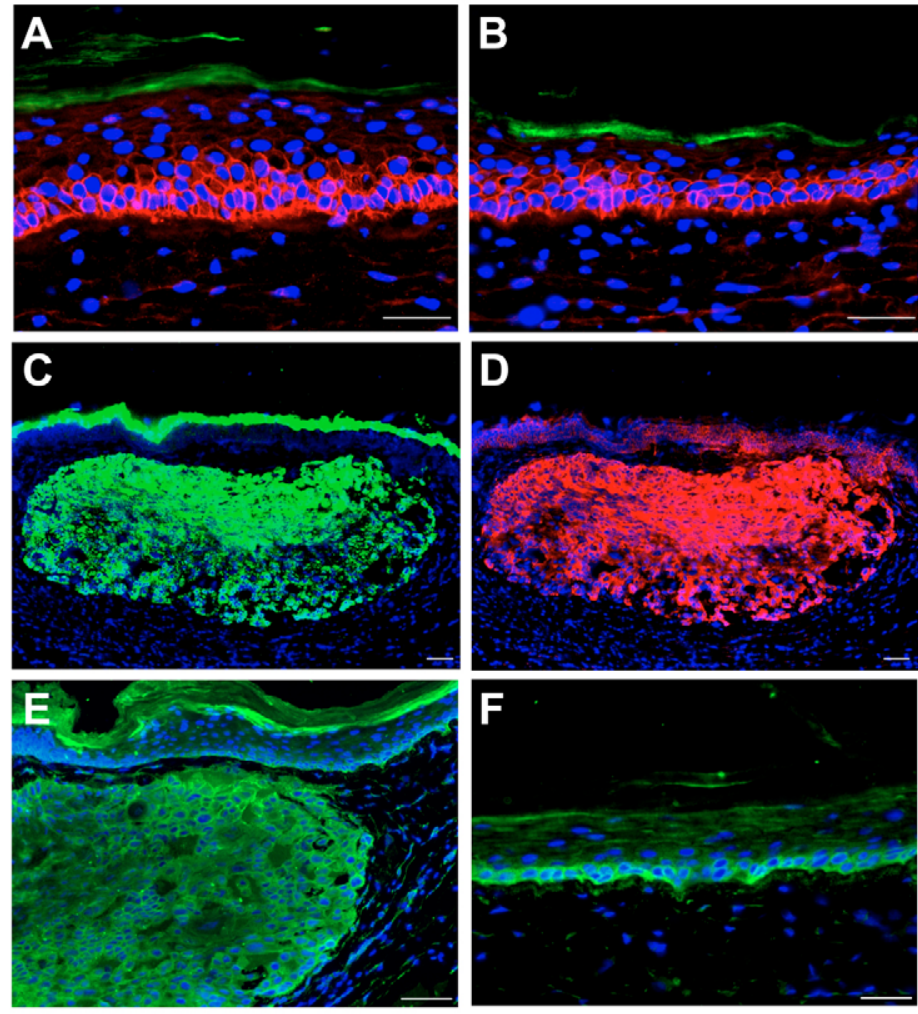

Fig. 2. Tumor cell invasion was linked to the cytoplasmic redistribution of $\beta$-catenin and increased expression of $\alpha 2$ integrin subunit. (A-F) Four weeks after in vivo transplantation of $4: 1$ mixtures, excised tissues were stained by double immunofluorescence for $\beta$-gal (green) and $\beta$ catenin (red). In transplanted mixtures comprised of HEK and control pBabe- (A) or EcadC25-expressing II-4 cells (B), $\beta$-gal-positive II-4 cells were not present and $\beta$-catenin was localized at cell-cell borders of the HEK cells. By contrast, as can be seen by the same immunostaining pattern, mixtures of HEK and $\mathrm{H} 2 \mathrm{k}^{\mathrm{d}}$-Ecad-expressing II- 4 cells demonstrated islands of invasive tumor cells that showed cytoplasmic co-localization of $\beta$-gal $(\mathrm{C}$, green) and $\beta$-catenin $(\mathrm{D}, \mathrm{red})$, indicating that II- 4 cell invasion was associated with loss of $\beta$-catenin from cell junctions and abrogation of cell-cell adhesion. The invading clusters of tumor cells showed increased expression of $\alpha 2$ integrin subunit $(\mathrm{E}$, green), whereas in control grafts comprised of HEK and control pBabeII- 4 cells, $\alpha 2$ integrin expression was limited to the basal HEK at the epithelial-stromal interface (F, green). Bars, $10 \mu \mathrm{m}$.

control cells were exclusively observed in the suprabasal cell layers of the epithelium and had lost contact with the stromal interface (Fig. 3A,B, arrows). These findings suggested that loss of E-cadherin altered the adhesive repertoire of these cells, thus creating permissive conditions for their attachment and persistence in the basal layer. Moreover, these results identify two separate but mutually interdependent mechanisms by which loss of E-cadherin function may support initiation of squamous cell carcinoma progression. First, absence of E-cadherin function allowed these cells to evade tumor suppression mediated by cell-cell contact that could have prevented their persistence after in vivo transplantation. Secondly, loss of E-cadherin function enabled small numbers of II-4 cells to adhere to the stromal interface in vitro and, thus, to manifest their invasive potential after in vivo transplantation. 

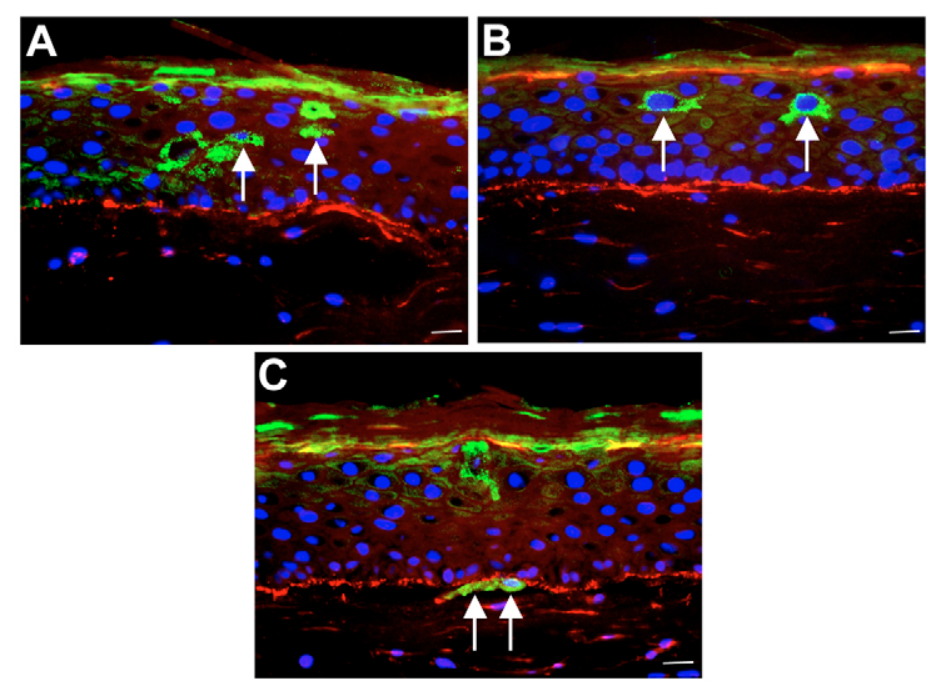

Loss of E-cadherin function is associated with enhanced cell-matrix adhesion

To determine whether the attachment of E-cadherin-deficient cells to the stromal interface prior to tumor cell invasion was due to changes in their adhesion to extracellular matrix components, short-term attachment assays were performed
A

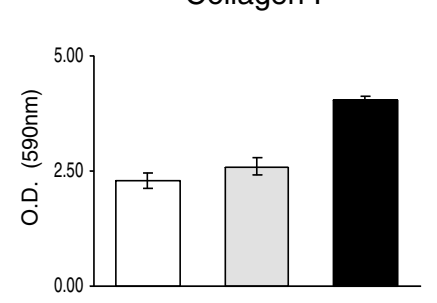

C

Laminin 1

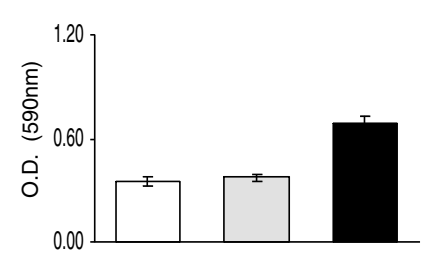

pBabe-II-4

\section{B}

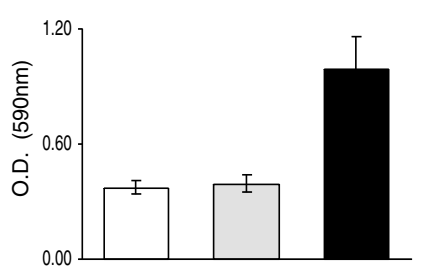

D

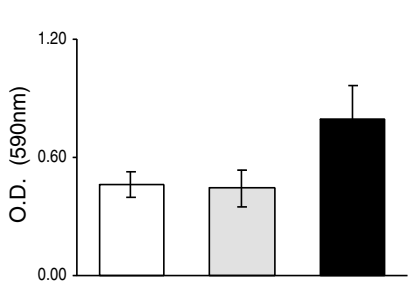

$H-2 k^{d}-E C a d C 25-I I-4$

$H-2 k^{d}-E c a d-I I-4$

Fig. 4. Loss of E-cadherin increases II-4 cell attachment to extracellular matrix proteins. 2D cultures of pBabe-, $\mathrm{H}-2 \mathrm{k}^{\mathrm{d}}-$ EcadC25- or H-2k ${ }^{\mathrm{d}}$-Ecad-II-4 cells were trypsinized briefly and replated onto plates coated with either Type I collagen (A), Type IV collagen (B), laminin-1 (C) or fibronectin (D) for 20 minutes. Attached cells were quantified by optical density determined at 590 $\mathrm{nm}$. Results are calculated as the mean \pm s.d. of four replicates and experiments were repeated four times. $P<0.01$ for $\mathrm{H}-2 \mathrm{k}^{\mathrm{d}}$-Ecad-II-4 cells vs control cells in adherence to Types I and IV collagen substrates. $P<0.05$ for $\mathrm{H}-2 \mathrm{k}^{\mathrm{d}}$-Ecad-II-4 cells vs control cells in adherence to laminin-1 and fibronectin substrates.
Fig. 3. Invasion of cell-cell adhesion-deficient II-4 cells was preceded by their attachment and localization at the epithelialstromal interface in $3 \mathrm{D}$ in vitro tissues. In vitro $3 \mathrm{D}$ cultures were constructed as 4:1 mixtures of HEK with either pBabe-, $\mathrm{H}-2 \mathrm{k}^{\mathrm{d}}$ EcadC25- or H-2 $\mathrm{k}^{\mathrm{d}}$-Ecad-II-4 cells and were grown at an airliquid interface for 7 days. Tissues were stained by double immunofluorescence for the basement membrane component Type IV collagen (red) and $\beta$-gal (green). Constructs harboring mixtures of HEK with either pBabe- (A, arrows) or $\mathrm{H}-2 \mathrm{k}^{\mathrm{d}}-$ EcadC25-expressing II-4 cells (B, arrows) demonstrated tumor cells that were limited to the suprabasal layers of the epithelium. By contrast, tissues harboring $\mathrm{H}-2 \mathrm{k}^{\mathrm{d}}$-Ecad-II- 4 cells

demonstrated $\beta$-gal-positive cells in the basal layer of the epithelium, adjacent to the Type IV collagen present at the epithelial-stromal interface (C, arrows). Bars, $10 \mu \mathrm{m}$.

in monolayer cultures. $\mathrm{H}-2 \mathrm{k}^{\mathrm{d}}$-Ecad-expressing II-4 cells demonstrated a significant increase in adhesion to surfaces coated with ECM substrates when compared with control pBabe- and H-2k ${ }^{\mathrm{d}}$ EcadC25-expressing II-4 cells (Fig. 4). This effect was most pronounced when $\mathrm{H}-2 \mathrm{k}^{\mathrm{d}}$-Ecad-expressing cells were seeded on the BM constituents Type IV collagen (3.5fold increase; Fig. 4B) and laminin (twofold increase; Fig. 4C). In addition, $\mathrm{H}-2 \mathrm{k}^{\mathrm{d}}$-Ecad-expressing II-4 cells demonstrated elevated adhesion to Type I collagen-coated (Fig. 4A) and fibronectin-coated (Fig. 4D) plates when compared with the control II-4 cells. This demonstrates that loss of E-cadherinmediated adhesion was associated with a general increase in the repertoire of matrix-adhesive receptors on the surface of these cells.

Loss of E-cadherin function in II-4 cells is associated with enhanced expression of $\alpha 2, \alpha 3$ and $\beta 1$ integrin subunits

To address the mechanism underlying augmented matrix adhesion of $\mathrm{H}-2 \mathrm{k}^{\mathrm{d}}$-Ecad-II-4 cells, we compared the levels of specific integrin subunits expressed on the surface of the three II-4 cell lines in 2D monolayer cultures. Immunoblotting of membrane extracts revealed a marked increase in the level of $\alpha 3$ integrin expression in E-cadherin-deficient, $\mathrm{H}-2 \mathrm{k}^{\mathrm{d}}$-Ecad-II4 cells, when compared with the relatively low $\alpha 3$ expression level present in the control pBabe-II-4 and in the $\mathrm{H}$ $2 \mathrm{k}^{\mathrm{d}}$ EcadC25-expressing II-4 cultures (Fig. 5A). As in invading tumor cells in nude mice, a similar increase in expression was observed for the $\alpha 2$ integrin subunit, in $\mathrm{H}-2 \mathrm{k}^{\mathrm{d}}$-Ecad-expressing cells, when compared with control pBabe-II-4 cells and with $\mathrm{H}-2 \mathrm{k}^{\mathrm{d}}$ EcadC25-expressing II-4 cells (Fig. 5A). However, in both control cultures, the expression level of $\alpha 2$ subunit was higher than the expression level of the $\alpha 3$ integrin subunit. As expected, the increased expression level of both $\alpha 3$ and $\alpha 2$ subunits was accompanied by an increased expression of the complementary $\beta 1$ integrin subunit in the $\mathrm{H}-2 \mathrm{k}^{\mathrm{d}}$-Ecadexpressing cells, in comparison to $\beta 1$ levels present in both control cultures.

These findings were supported by flow cytometric analysis of cell surface integrin expression of the three II- 4 cell lines under investigation. H-2 $\mathrm{k}^{\mathrm{d}}$-Ecad-II-4 and the control immunolabeled 
pBabe-II- 4 cells, and H-2k ${ }^{\mathrm{d}}$ EcadC25-expressing II- 4 cells were labeled with anti- $\alpha 2, \alpha 3$ or $\beta 1$ integrin antibodies. The levels of cell surface integrin subunits $\alpha 2, \alpha 3$ and $\beta 1$ were considerably increased in the E-cadherin-deficient, $\mathrm{H}-2 \mathrm{k}^{\mathrm{d}}$-Ecad-II-4 cells, when compared with levels of these cell surface integrin subunits in the control pBabe-II-4 cells (Fig. 5B, right panel). By contrast, no significant differences in cell surface integrin levels of $\alpha 2, \alpha 3$ and $\beta 1$ subunits were identified between control pBabe-II- 4 cells and $\mathrm{H}-2 \mathrm{k}^{\mathrm{d}} \mathrm{EcadC} 25-\mathrm{II}-4$ cells (Fig. 5B, left panel).

Finally, to determine the functional significance of the increased expression of the integrin subunits in $\mathrm{H}-2 \mathrm{k}^{\mathrm{d}}$-Ecad-II4 cells, short-term adherence assays to Type I and IV collagen and to laminin 1 substrates were performed in the presence or absence of $\beta 1$ integrin blocking antibodies. As seen in Fig. 5C, the presence of specific $\beta 1$-blocking antibodies dramatically reduced the ability of $\mathrm{H}-2 \mathrm{k}^{\mathrm{d}}$-Ecad-II-4 cells to adhere to Type I and IV collagens (80\% and 55\% decrease, respectively). By contrast, cells adhered to a lesser extent to laminin 1 and were mildly affected by the presence of $\beta 1$ blocking antibodies (Fig. 5C, 20\% decrease). Taken together these results demonstrate that loss of E-cadherin-mediated cell-cell adhesion was associated with increased expression of functioning cell surface $\alpha 2, \alpha 3$ and $\beta 1$ integrin subunits. Furthermore, this increase in integrin expression is correlated with the ability of these cells to adhere rapidly to Type I and IV collagens, that are present at the epithelial-stromal interface.

\section{Discussion}

Microenvironmental cues inherent in normal tissue architecture are known to limit the malignant potential of precancerous tumor cells through an intrinsic, tissue-based control of early cancer progression (Bissell and Radisky, 2001; Alt-Holland et al., 2005). Consistent with this notion, we have previously established that interactions between tumor cells and adjacent normal keratinocytes induce a state of 'intraepithelial dormancy' in which premalignant tumor cells embedded in the stratifying epidermis withdraw from the cell cycle, lose attachment to the basement membrane and are eventually lost along with terminally differentiating keratinocytes (Javaherian et al., 1998). Here we report that this barrier to early squamous carcinoma progression can be overcome through previously unknown molecular events incurred upon loss of E-cadherin function in epithelial cells with malignant potential. Specifically, disruption of E-cadherin function in H-Ras-transformed human cell line was associated with an increase in integrin-mediated adhesion that enabled intraepithelial (IE) tumor cells to adhere to the epithelialstromal interface in 3D tissue reconstructs. This increased adhesion set the stage for invasion of tumor cells that was observed after transplantation of skin reconstructs to immunodeficient mice. Collectively, these results suggest a novel role for E-cadherin loss in the initiation of epithelial tumor progression that arose from linkage between loss of cellcell adhesion and gain of cell-matrix adhesion.

Both integrin-mediated cell-matrix adhesion and cadherinmediated cell-cell adhesion are known to play central roles in tumor cell adhesion, migration, invasion, and metastasis (Cavallaro and Christofori, 2004; Friedl and Wolf, 2003). Recent studies using monolayer cultures of epithelial cancer cells revealed a complex network of molecular pathways linking cell-cell and cell-matrix adhesion. For example, integrin-mediated loss of E-cadherin from cell-cell junctions is associated with overexpression of $s r c$ in colon carcinoma cells. In addition, integrin-linked kinase has been shown to control Ecadherin expression (Wu et al., 1999) and elements of the integrin signaling complex regulate $\mathrm{N}$-cadherin-mediated adhesion (Gotzman et al., 2004). Furthermore, abrogation of Ecadherin function in breast cancer cells resulted in increased activity of the $\alpha \mathrm{v}$ integrin subunit and increased cell migration (van Schliepp et al., 2000). We extend these earlier observations into 3D human tissue constructs by describing increased surface localization and function of $\beta 1$ integrins upon loss of Ecadherin in II-4 cells. Upregulation of $\alpha 2, \alpha 3$ and $\beta 1$ integrin subunits was paralleled by increased adhesion to extracellular matrix components, particularly laminin and Type IV collagen. Furthermore, only IE tumor cells that had lost functional adherens junctions, as seen by the cytoplasmic redistribution of $\beta$-catenin, were retained at the stromal interface in vitro. Thus, the present investigation demonstrates for the first time, that the mutually interdependent regulation of cell-cell and cell-matrix adhesion has significant consequences for the initial stages of epithelial cancer progression in 3D human tissues that mimic their in vivo counterparts.

The ability of E-cadherin-deficient II-4 cells to initiate invasion in the context of NHK is due specifically to increased integrin-mediated attachment to Types I and IV collagen at the epithelial-stromal interface. We have performed functionblocking studies using antibody directed against $\beta 1$ integrin to show that this adhesion can be significantly limited when these cells are exposed to this blocking antibodies. Thus, increased expression and function of $\alpha 2, \alpha 3$ and $\beta 1$ integrin subunits seen upon loss of E-cadherin function, enables adhesion of Ecadherin-deficient cells that is specific to these ECM proteins. These findings now enable us to hypothesize how the link between loss of E-cadherin and gain of specific integrin subunits allow intraepithelial tumor cells to manifest their invasive behavior. First, loss of E-cadherin and increased integrin function enables adhesion specifically to Type I collagen, which was the predominant protein present at the stromal interface when 3D cultures were seeded onto Type I collagen gels. Type IV collagen may also play a role in the retention of E-cadherin-deficient cells, as it is subsequently deposited by II- 4 cells in the basal layer several days after cells are seeded into 3D tissues (Andriani et al., 2004). Interestingly, integrin-mediated binding to laminin-1 does not appear to play a role during these events, as integrin-blocking antibodies do not significantly decrease the adhesion of E-cad-deficient cells. It is possible that this laminin may play a role in adhesion through non-integrin receptors (Kim et al., 1999). Thus, only after attachment of E-cadherin-deficient cells to Type I and IV collagen at the stromal interface will these cells realize their malignant potential by overcoming local, microenvironmental constraints. This points to a crucial role for the loss of Ecadherin and acquisition of specific ECM attachment in the initiation of tumor cell invasion.

Acquisition of an invasive phenotype is a crucial event in early tumor progression, as this property is a prerequisite for connective tissue infiltration and metastatic dissemination associated with poor clinical outcomes. A molecular mechanism recognized to guard against invasion and metastasis is apoptosis or anoikis that is incurred upon loss of integrinmediated ECM adhesion (Meredith et al., 1993; Frisch 
and Francis, 1994). Anoikis has been described for both immortalized human keratinocytes with low malignant potential (Jost et al., 2001) and for SCC cell lines at a more advanced stage of tumor progression (Kim et al., 1999; Janes and Watt, 2004). Recently, anoikis was shown to be induced by the forced expression of $\alpha \mathrm{v}$ integrin in an $\alpha \mathrm{v}$-negative SCC line,
A

$\alpha 2$
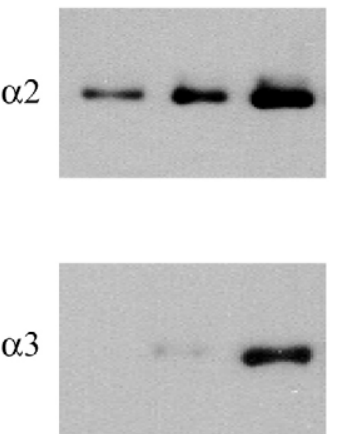

$\beta 1$

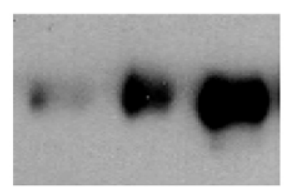

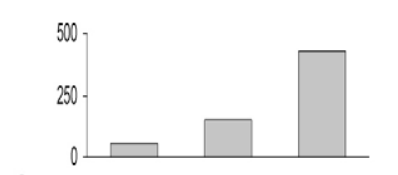

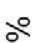

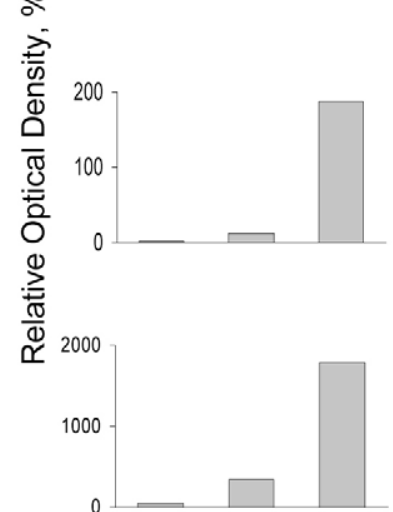

B

pBabe-II-4 / H-2k ${ }^{\mathrm{d}}$-ECadC25-II-4

pBabe-II-4 / H-2kd -ECad-II-4
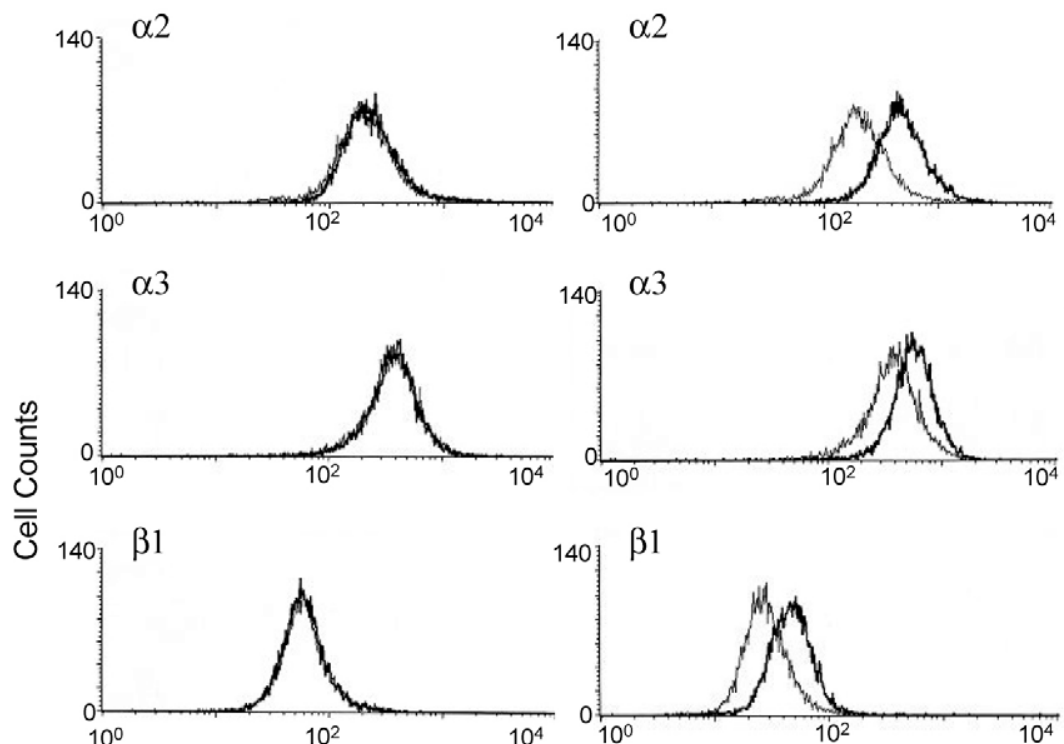

Fig. 5. Loss of E-cadherin in II-4 cells is linked to increased expression of $\alpha 2, \alpha 3$ and $\beta 1$ intregrin subunits. (A) Expression levels of integrin subunits on the cell surface of $\mathrm{pBabe}-\mathrm{H}-2 \mathrm{k}^{\mathrm{d}}$-EcadC25- or H-2 $\mathrm{k}^{\mathrm{d}}$-Ecad-II-4 in $2 \mathrm{D}$ cultures. The three cell types were extracted and $5 \mu \mathrm{g}$ samples of membrane proteins were immunoblotted in non-reducing conditions with anti- $\alpha 2$, anti- $\alpha 3$ or anti- $\beta 1$ integrin antibodies and analyzed by ECL. Expression levels of these specific integrin subunits were markedly increased in E-cadherin deficient $\mathrm{H}-2 \mathrm{k}^{\mathrm{d}}$-Ecad-II-4 cells, when compared with their levels in the control pBabe- and $\mathrm{H}-2 \mathrm{k}^{\mathrm{d}}$-EcadC25-II-4 cells (left panel). Scanning densitometry of the relative intensity of the presented immunoblots is shown on the right. (B) FACS analysis of pBabe-, H-2 $\mathrm{k}^{\mathrm{d}}$-EcadC25- or H-2k ${ }^{\mathrm{d}}$-Ecad-II-4 cells immunoreacted with antibodies against specific integrin subunits. Elevated levels of cell surface $\alpha 2, \alpha 3$ and $\beta 1$ subunits in H-2kd-Ecad-II-4 cells (black line in right-hand panels) in comparison to control pBabe-II-4 cells (gray line) were identified by increased fluorescence intensity seen in E-cadherin deficient cells. The expression levels of $\alpha 2, \alpha 3$ and $\beta 1$ subunits were similar in $\mathrm{H}-2 \mathrm{k}^{\mathrm{d}}$-EcadC25-II4 (black line in left-hand panels) and the control pBabe-II4 cells (gray line) as seen by the superimposition of these lines. (C) Functional blocking of $\beta 1$ integrin in $\mathrm{H}-2 \mathrm{k}^{\mathrm{d}}$ -
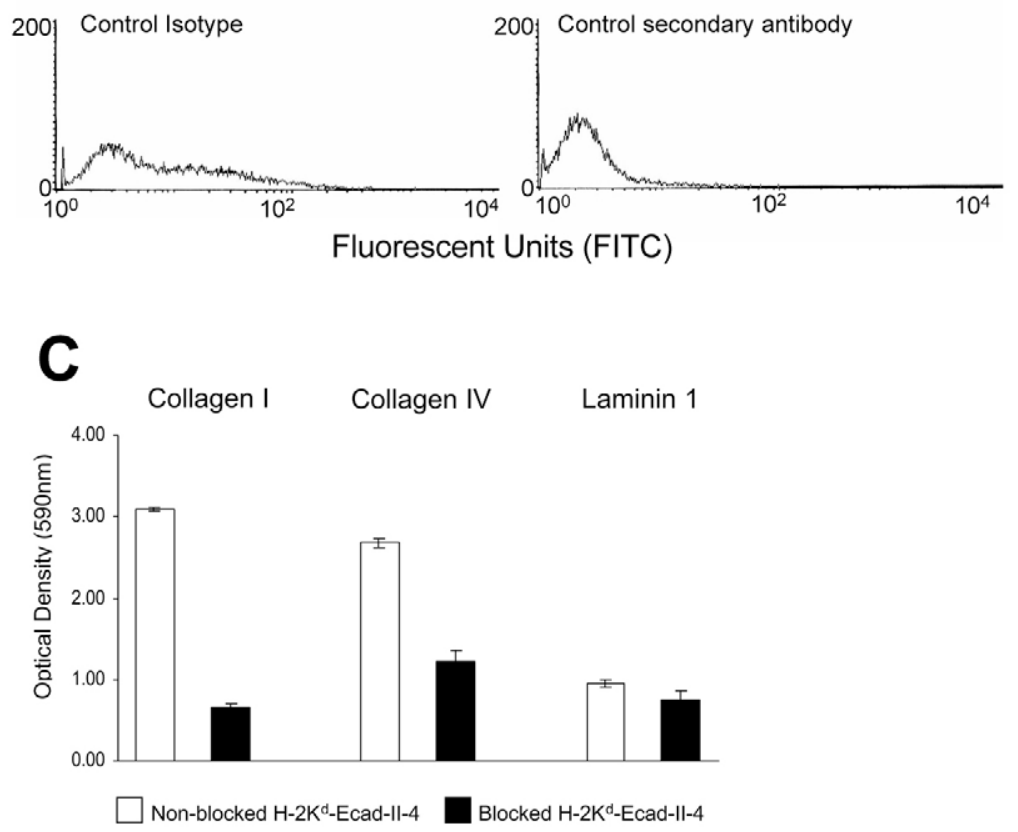

Ecad-II-4 cells. Two-dimensional cultures of Ecad-

deficient $\mathrm{H}-2 \mathrm{k}^{\mathrm{d}}$-Ecad-II-4 cells were trypsinized briefly and replated for 15 minutes onto Type I and IV collagens or laminin-1 substrates, in the presence or absence of $\beta 1$-integrin-blocking antibodies. Attached cells were quantified by optical density determined at $590 \mathrm{~nm}$. Results are calculated as the mean \pm s.d. of four replicates and experiments were repeated three times. $P<0.001$ for cell adherence to Type I collagen, Type IV collagen and laminin-1 substrates compared with levels in blocked controls. 
demonstrating that levels of integrin subunit expression could modulate anoikis susceptibility and survival signaling (Janes and Watt, 2004). Interestingly, previous work also demonstrated that E-cadherin-mediated adhesion can counteract the requirement for matrix adhesion for epithelial cell survival thus enabling cells to circumvent anoikis (Kim et al., 1999; Green et al., 2004). These observations raise the question as to how loss of E-cadherin function could actually enhance survival and invasion of tumor cells in 3D tissue context as described in the present study. To reconcile these seemingly conflicting results we propose a dual role for E-cadherin in epithelial cell survival. When present in normal stratified squamous epithelial cells, Ecadherin may provide a physiological mechanism to counteract apoptosis induced by loss of ECM attachment as cells transit through suprabasal strata. However, when E-cadherin expression and/or function is lost during the early stages of epithelial neoplasia, small numbers of IE tumor cells are able to gain increased adhesion to extracellular matrix components at the BM, thus offsetting the loss of E-cadherin-mediated survival signals. Increased adhesion to the BM thus leads to intraepithelial retention of tumor cells at a site in the tissue that can subsequently facilitate initiation of tumor cell invasion.

The II-4 cell line used in our studies has been well characterized and represents an early stage of the malignant transformation process (Boukamp et al., 1990). Since II-4 cells harbor many of the important genetic hallmarks of the premalignant and early, invasive stages of SCC, such as mutations in the p53 gene and activation of Ha-Ras, this cell line is optimal for incorporation into models of early carcinoma progression. It is also important to understand if this genetic background contributes to the acquisition of adhesive and invasive properties seen upon loss of E-cadherin function in these cells. It is known that oncogenic Ha-Ras signaling cooperates with TGF- $\beta$ to cause epithelial-mesenchymal transition (EMT) (Janda et al., 2002), that is a crucial event in late-stage tumorigenesis of transformed epithelial cells (Mercer et al., 2000). However, in early-stage tumor cells such as II-4, it is thought that mutation of the Ha-Ras gene may be more directly related to growth-regulatory pathways (Delhedde, 1999) rather than altering cell adhesion. As recently shown, E-cadherin-deficient-II-4 cells do not show all features of EMT (Margulis et al., 2005a), suggesting that the combinatorial effect of Ha-Ras activation, p53 loss and Ecadherin suppression are insufficient to fully induce EMT in these early-stage tumor cells.

While highlighting a novel aspect of E-cadherin loss in epithelial tumor progression, the current study extends our previous observations that loss of E-cadherin induces a highly aggressive tumor behavior in pure cultures of E-cadherin deficient cells (Margulis et al., 2005b) to mixtures of these cells with HEK. Only when the behavior of these cells was studied in the context of HEK has it been possible to determine that suppression of E-cadherin expression can induce loss of microenvironmental control of the malignant phenotype in II-4 cells in 3D tissues that mimic human premalignant disease. Similar impediments to tumor development inherent in 3D tissue context have been described in other tissue types, such as breast and prostate. For example, $\beta 1$-integrin-mediated interactions between a premalignant breast epithelial cell line and adjacent ECM proteins have been shown to revert the malignant phenotype in a 3D model of early breast cancer progression (Miranti and Brugge, 2002; Wang et al., 1998; Schmeichel et al., 1998) by normalizing the distribution of Ecadherin upon reversion of malignant mammary epithelial cells to a normal phenotype (Weaver et al., 1997). Collectively, these observations demonstrate that genetic alterations present in individual initiated cells with malignant potential can have important functional consequences beyond tumor-autonomous roles in regulating cell cycle progression or cell survival. Rather, as in the case of E-cadherin loss, they significantly affect the complex interplay of tumor cells with the environment they find themselves in (Bissell and Radisky, 2001).

Our findings show that the integration of changes in cell-cell and cell-matrix adhesion are central to the conversion from premalignant lesions to early invasive carcinoma. These findings offer insight into incipient cancer invasion by demonstrating that microenvironmental, selective pressure drives the progression of precancer to fully-invasive tumors (Alt-Holland et al., 2005). This may help to explain why premalignant lesions such as actinic keratosis of skin, cervical dysplasia, oral leukoplakia and lobular carcinoma of the breast may contain numerous clones of initiated or dysplastic cells, yet have an unpredictable biological behavior that does not always advance to invasive cancer. By further understanding the progression of precancer to malignancy and by exploring signaling pathways associated with this transition in human 3D in-vivo-like tissue constructs, new therapeutic modalities designed to abrogate these events may be formulated to block early cancer invasion and thus prevent cancer occurrence.

\section{Materials and Methods}

\section{D cell culture}

Human epidermal keratinocytes (HEK) were cultured from infant foreskin and were grown on an irradiated 3T3 fibroblast feeder layer, in DMEM containing 10\% fetal calf serum (FCS). HaCaT-ras-II-4 (II-4) keratinocytes (Boukamp et al., 1990) that constitutively expressed the $\beta$-galactosidase gene to allow their identification in the context of HEK, were grown in DMEM containing 5\% FCS. Two-dimensional, monolayer cultures of human dermal fibroblasts used for organotypic cultures were derived from infant foreskin and grown in media containing $10 \%$ FCS.

\section{Retroviral infection}

The dominant-negative retroviral E-cadherin vector $\left(\mathrm{H}-2 \mathrm{k}^{\mathrm{d}}\right.$-Ecad $)$ was a chimeric protein bearing the extracellular domain of mouse MHC class I antigen $\mathrm{H}-2 \mathrm{~K}^{\mathrm{d}}$ linked to the transmembrane domain of mouse E-cadherin (Zhu and Watt, 1996). Control vectors included $\mathrm{H}-2 \mathrm{~K}^{\mathrm{d}}$-EcadC25, constructed from the $\mathrm{H}-2 \mathrm{k}^{\mathrm{d}}$-E-cad vector with a 25 amino acid deletion in the $\beta$-catenin-binding domain and the empty retroviral vector pBabe. The 293 Phoenix retroviral producer cells maintained in DMEM containing $10 \%$ bovine calf serum were transfected with pBabe, $\mathrm{H}-2 \mathrm{~K}^{\mathrm{d}}$ Ecad and $\mathrm{H}-2 \mathrm{~K}^{\mathrm{d}}$-EcadC25 plasmids (courtesy of F. Watt, Imperial Cancer Research Center, London, United Kingdom) by the calcium phosphate method.

\section{D cell culture and construction of premalignant tissues}

Human tissue 3D constructs were prepared as previously described (Kolodka et al., 1998). HEK and II-4 cells that expressed each of the three retroviral constructs were mixed at 4:1 HEK:II-4 and $5 \times 10^{5}$ cells from each cell mixture were seeded onto contracted collagen gels. Cultures were maintained submerged in low-calcium epidermal growth media for 2 days, submerged for 2 days in normal calcium epidermal growth media and raised to an air liquid interface for 5 days.

\section{Transplantation of 3D cultures to nude mice}

Three-dimensional tissue constructs were transplanted to the dorsum of 6-week-old male Swiss nude mice (N:NIHS-nuf DF; Taconic farms, Germantown, NY) and animals were sacrificed 4 weeks after transplantation. For routine light microscopy, tissues were fixed in $10 \%$ neutral-buffered formalin, embedded in paraffin and 4 $\mu \mathrm{m}$ sections were stained with Hematoxylin and Eosin (H\&E). Animal experiments were performed with the approval of the State University of New York (SUNY) Stony Brook Institutional Animal Care and Use Committees (IACUC).

Immunofluorescence staining

Tissue specimens were frozen in liquid nitrogen vapor and $6 \mu \mathrm{m}$ serial sections were 
mounted onto glass slides. Double immunofluorescent stains were performed using rabbit anti- $\beta$-gal (Cortex pharmaceuticals, CA) to detect II- 4 cells and mouse anti$\beta$-catenin (Zymed, CA) or mouse anti-Type IV collagen (Sigma) antibodies and detected using FITC-conjugated goat anti-rabbit $\operatorname{IgG}$ (Vector laboratories, $\mathrm{CA}$ ) and Alexa Fluor 594-conjugated goat anti-mouse IgG (Molecular Probes, OR) antibodies. Fluorescence was visualized using a Nikon OptiPhot microscope.

\section{Cell-matrix adhesion and functional blocking assays}

Twenty-four-well plates coated with either Type I collagen, Type IV collagen, laminin, or fibronectin (Becton Dickinson, MA) were rinsed with PBS, blocked with $2 \%$ heat-denatured BSA at room temperature for 1 hour and rinsed again with PBS. II-4 cells expressing either of the E-cadherin vectors, or containing the pBabecontrol vector, were trypsinized and resuspended in serum-free DMEM. Cells $\left(5 \times 10^{4}\right)$ were plated into each well, and plates were incubated at $37^{\circ} \mathrm{C}$ for 20 minutes. Cells were fixed at room temperature in $2 \%$ glutaraldehyde and nonadherent cells were removed by rinsing the plates several times in double-distilled $\mathrm{H}_{2} \mathrm{O}$. Plates were air-dried and adherent cells were stained with $0.1 \%$ crystal violet in $200 \mathrm{mM}$ boric acid for 20 minutes. Plates were rinsed, air-dried and $10 \%$ acetic acid was added to each well. Optical density was determined at $590 \mathrm{~nm}$.

For functional antibody blocking studies, cells were trypsinized, washed, resuspended in serum-free DMEM and preincubated for 45 minutes at $37^{\circ} \mathrm{C}$ in the absence (control, untreated cells) or the presence of $20 \mu \mathrm{g} / \mathrm{ml}$ of mouse anti-human $\beta 1$-integrin function-blocking mAb (clone P5D2, Chemicon, Temecula, CA). Untreated II-4 cells or $\beta 1$ integrin blocked II-4 cells $\left(5 \times 10^{4}\right.$ of each) were plated into each well and incubated at $37^{\circ} \mathrm{C}$ for 15 minutes. Thereafter, the procedure for fixing the cells, staining adherent cells and determination of optical density was the same as described above for adhesion assay.

\section{Cell membrane fractionation and western blot analysis}

Monolayer 2D cultures were extracted on ice into $400 \mu \mathrm{l}$ cold PBS buffer containing $150 \mathrm{mM} \mathrm{NaCl}, 50 \mathrm{mM}$ Tris- $\mathrm{HCl} \mathrm{pH}$ 7.5, $10 \mathrm{mM}$ EDTA, $10 \mathrm{mM} \mathrm{NaF}, 10 \mu \mathrm{g} / \mathrm{ml}$ aprotinin and leupeptin, $2 \mu \mathrm{g} / \mathrm{ml}$ pepstatin, $1 \mathrm{mM} \mathrm{PMSF}$ and $200 \mu \mathrm{l} \mathrm{NaVO}$ (Sigma, St. Louis, MO). Cell lysates were subjected to five freeze-thaw cycles, centrifuged at $16,000 \mathrm{~g}$ for 25 minutes at $4{ }^{\circ} \mathrm{C}$ and pellets were resuspended in $60 \mu \mathrm{PBS}$ containing $1 \%$ Triton X-100 as well as proteinase and phosphatase inhibitors. Pellets were homogenized four times over a 30 minute incubation on ice and centrifuged at $16,000 \mathrm{~g}$ for 25 minutes at $4^{\circ} \mathrm{C}$. Protein concentration of the supernatant membrane fraction was measured using a modified Lowry assay (Bio-Rad DC Protein Assay Kit). For integrin analysis, $5 \mu \mathrm{g}$ protein samples were boiled in Laemmli sample buffer without 2- $\beta$-Me, loaded onto 7.5\% SDS-PAGE gel and separated proteins were transferred to a nitrocellulose membrane (Bio-Rad). Immunoblotting was performed using rabbit anti-human integrin $\alpha 2$, rabbit antihuman integrin $\alpha 3$ or mouse anti-human $\beta 1$ integrin antibodies (Chemicon) following by HRP-anti-rabbit or HRP-anti-mouse IgG antibodies (Amersham, Piscataway, NJ). Protein bands were visualized by ECL, utilizing Pierce SuperSignal Kit (Rockford, IL).

\section{Flow cytometry analysis of cell surface integrins}

II-4 cells expressing either of the E-cadherin vectors or the pBabe-control vector were trypsinized, washed in serum-containing medium, and rinsed twice in cold PBS. Cells were resuspended and incubated for 30 minutes on ice in cold PBS with either mouse anti-human integrin $\alpha 2$, integrin $\alpha 3$ or integrin $\beta 1$ antibodies (Chemicon). Cells were then washed twice in cold PBS and incubated on ice for 30 minutes with goat-anti mouse FITC-conjugated secondary antibody. Following extensive washing with cold PBS, cells were resuspended in PBS containing propidium iodide and live cells analyzed by the cell-sorter FACS Vantage (Becton-Dickinson Immunocytometry Systems, Mountain View, CA). Control cell samples for analyzing the background levels of immunostaining were incubated with either secondary antibody alone or unrelated mouse $\mathrm{IgG}$ and were used as negative controls.

We thank F. Watt for the gift of the chimeric, E-cadherin retroviral vectors. In addition, we would like to thank Ning Lin, Padmaja Prabhu, Marc Mendelsohn, Laura Bertolotti, Jennifer Landmann, Lorne Taichman and Larry Pfeiffer for their assistance. This work was supported by grant \#2RO1DE011250-06 from the National Institutes of Dental and Craniofacial Research.

\section{References}

Alt-Holland, A., Zhang, W., Margulis, A. and Garlick, J. A. (2005). Microenvironmental control of premalignant disease. The role of intercellular adhesion in the progression of intraepithelial neoplasia. Semin. Cancer Res. 15, 84-96.

Andriani, F., Garfield, J., Fusenig, N. E. and Garlick, J. A. (2004). Basement membrane proteins promote progression of intraepithelial neoplasia in 3-dimensional models of human stratified epithelium. Int. J. Cancer 108, 348-357.

Avizienyte, E., Wyke, A. W., Jones, R. J., McLean, G. W., Westhoff, M. A., Brunton, V. G. and Frame, M. C. (2002). Src-induced de-regulation of E-cadherin in colon cancer cells requires integrin signalling. Nat. Cell Biol. 4, 632-638.
Birchmeier, W. and Behrens, J. (1994). Cadherin expression in carcinomas: role in the formation of cell junctions and the prevention of invasiveness. Biochim. Biophys. Acta 1198, 11-26.

Bissell, M. J. and Radisky, D. (2001). Putting tumors in context. Nat. Rev. Cancer 1, 4654.

Boukamp, P., Stanbridge, E. J., Foo, D. Y., Cerutti, P. A. and Fusenig, N. E. (1990). c-Ha-ras oncogene expression in immortalized human keratinocytes $(\mathrm{HaCaT})$ alters growth potential in vivo but lacks correlation with malignancy. Cancer Res. 50, 28402847.

Cano, A., Perez-Moreno, M. A., Rodrigo, I., Locascio, A., Blanco, M. J., del Barrio, M. G., Portillo, F. and Nieto, M. A. (2000). The transcription factor snail controls epithelial-mesenchymal transitions by repressing E-cadherin expression. Nat. Cell Biol. 2, 76-83.

Cavallaro, U. and Christofori, G. (2004). Call adhesion and signaling by cadherins and Ig-CAMs in cancer. Nat. Rev. Cancer 4, 118-132.

Delhedde, M., Song, H. C., Hamm, R., Brisbay, S., Ananthaswamy, H. N., Kripke, M. and McDonnell, T. J. (2001). Impact of Bcl-2 and Ha Ras on keratinocytes in organotypic culture. J. Invest. Dermatol. 116, 366-373.

Dlugosz, A., Merlino, G. and Yuspa, S. H. (2002). Progress in cutaneous cancer research. J. Invest. Dermatol. Symp. Proc. 7, 17-26.

Friedl, P. and Wolf, K. (2003). Tumour-cell invasion and migration: diversity and escape mechanisms. Nat. Rev. Cancer 3, 362-374.

Frisch, S. M. and Francis, H. (1994). Disruption of epithelial cell-matrix interactions induces apoptosis. J. Cell Biol. 124, 619-626.

Gotzmann, J., Mikula, M., Eger, A., Schulte-Hermann, R., Foisner, R., Beug, H. andMikulits, W. (2004). Molecular aspects of epithelial cell plasticity: implications for local tumor invasion and metastasis. Mut. Res. 566, 9-20.

Green, S. K., Francia, G., Isidoro, C. and Kerbel, R. S. (2004). Antiadhesive antibodies targeting E-cadherin sensitize multicellular tumor spheroids to chemotherapy in vitro. Mol. Cancer Ther. 3, 149-159.

Jamora, C. and Fuchs, E. (2002). Intercellular adhesion, signalling and the cytoskeleton. Nat. Cell Biol. 4, E101-E108.

Janda, E., Lehmann, K., Killisch, I., Jechlinger, M., Herzig, M., Downward, J., Beug, H. and Grunert, S. (2002). Ras and TGF [beta] cooperatively regulate epithelial cell plasticity and metastasis: dissection of Ras signaling pathways. J. Cell Biol. 156, 299313.

Janes, S. M. and Watt, F. M. (2004). Switch from alphavbeta5 to alphavbeta6 integrin expression protects squamous cell carcinomas from anoikis. J. Cell Biol. 166, 419-431.

Javaherian, A., Vaccariello, M., Fusenig, N. E. and Garlick, J. A. (1998). Normal keratinocytes suppress early stages of neoplastic progression in stratified epithelium. Cancer Res. 58, 2200-2208.

Jost, M., Kar, C. and Rodeck, U. (2001). Matrix-independent survival of human keratinocytes through activation of the EGF receptor. Mol. Biol. Cell 12, 1519-1527.

Karen, J., Wang, Y., Javaherian, A., Vaccariello, M., Fusenig, N. E. and Garlick, J. A. (1999). 12-O-tetradecanoylphorbol-13-acetate induces clonal expansion of potentially malignant keratinocytes in a tissue model of early neoplastic progression. Cancer Res. 59, 474-481.

Kim, W. H., Lee, B. L., Kim, D. K. and Kleinman, H. K. (1999). Laminin-1-adherent cancer cells show increased proliferation and decreased apoptosis in vivo. Anticancer Res. 19, 3067-3071.

Kolodka, T. M., Garlick, J. A. and Taichman, L. B. (1998). Evidence for keratinocyte stem cells in vitro: long term engraftment and persistence of transgene expression from retrovirus-transduced keratinocytes. Proc. Natl. Acad. Sci. USA 95, 4356-4361.

Margulis, A., Zhang, W., Alt-Holland, A., Pawagi, S., Pfieffer, L., Garfield, J., Fusenig, N. E. and Garlick, J. A. (2005a). Loss of intercellular adhesion activates a transition from low- to high-grade human squamous cell carcinoma. Int. J. Cancer doi:10.1002/ijs.21409.

Margulis, M., Zhang, W., Alt-Holland, A., Crawford, H., Fusenig, N. E. and Garlick, J. A. (2005b). E-cadherin suppression accelerates squamous cell carcinoma progression in 3D human tissue constructs Cancer Res. 65, 1783-1791.

Mercer, J. A. (2000). Intercellular junctions: downstream and upstream of Ras? Semin. Cell Dev. Biol. 11, 309-314.

Meredith, J. E., Jr, Fazeli, B. and Schwartz, M. A. (1993). The extracellular matrix as a cell survival factor. Mol. Biol. Cell 4, 953-961.

Miranti, C. K. and Brugge, J. S. (2002). Sensing the environment: a historical perspective on integrin signal transduction. Nat. Cell Biol. 4, E83-E90.

Mudgil, A. V., Segal, N., Andriani, F., Wang, Y., Fusenig, N. E. and Garlick, J. A. (2003). Ultraviolet B irradiation induces expansion of intraepithelial tumor cells in a tissue model of early cancer progression. J. Invest. Dermatol. 121, 191-197.

Perl, A. K., Wilgenbus, P., Dahl, U., Semb, H. and Christofori, G. (1998). A causal role for E-cadherin in the transition from adenoma to carcinoma. Nature 392, 190-193.

Schmeichel, K. L., Weaver, V. M. and Bissell, M. J. (1998). Structural cues from the tissue microenvironment are essential determinants of the human mammary epithelial cell phenotype. J. Mammary. Gland Biol. Neoplasia 3, 201-213.

Vaccariello, M., Javaherian, A., Wang, Y., Fusenig, N. E. and Garlick, J. A. (1999). Cell interactions control the fate of malignant keratinocytes in an organotypic model of early neoplasia. J. Invest. Dermatol. 113, 384-391.

von Schlippe, M., Marshall, J. F., Perry, P., Stone, M., Zhu, A. J. and Hart, I. R. (2000). Functional interaction between E-cadherin and alphav-containing integrins in carcinoma cells. J. Cell Sci. 113, 425-437.

Wang, F., Weaver, V. M., Petersen, O. W., Larabell, C. A., Dedhar, S., Briand, P., Lupu, R. and Bissell, M. J. (1998). Reciprocal interactions between $\beta 1$-integrin and epidermal growth factor receptor in three-dimensional basement membrane breast cultures: a different perspective in epithelial biology. Proc. Natl. Acad. Sci. USA 95, 14821-14826. 
Weaver, V. M., Petersen, O. W., Wang, F., Larabell, C. A., Briand, P., Damsky, C. and Bissell, M. J. (1997). Reversion of the malignant phenotype of human breast cells in three-dimensional culture and in vivo by integrin blocking antibodies. J. Cell Biol. 137, 231-245.

Wu, C. (1999). Integrin-linked kinase and PINCH: partners in regulation of cell-extracellular matrix interaction and signal transduction. J. Cell Sci. 112, 44854489.

Yano, H., Mazaki, Y., Kurokawa, K., Hanks, S. K., Matsuda, M. and Sabe, H. (2004).
Roles played by a subset of integrin signaling molecules in cadherin-based cell-cell adhesion. J. Cell Biol. 166, 283-295.

Zhang, F., Tom, C. C., Kugler, M. C., Ching, T. T., Kreidberg, J. A., Wei, Y. and Chapman, H. A. (2003). Distinct ligand binding sites in integrin alpha3beta1 regulate matrix adhesion and cell-cell contact. J. Cell Biol. 163, 177-188.

Zhu, A. J. and Watt, F. M. (1996). Expression of a dominant negative cadherin mutant inhibits proliferation and stimulates terminal differentiation of human epidermal keratinocytes. J. Cell Sci. 109, 3013-3023. 


\title{
Malignant Transformation of Immortalized HaCaT Keratinocytes through Deregulated Nuclear Factor $\kappa B$ Signaling
}

\author{
Qing Ren, ${ }^{1}$ Csaba Kari, ${ }^{2}$ Marlene R.D. Quadros, ${ }^{2}$ Randy Burd, ${ }^{1}$ Peter McCue, \\ Adam P. Dicker, ${ }^{1}$ and Ulrich Rodeck ${ }^{2}$ \\ Departments of ${ }^{1}$ Radiation Oncology, ${ }^{2}$ Dermatology and Cutaneous Biology, and ${ }^{3}$ Pathology, Thomas Jefferson University, \\ Philadelphia, Pennsylvania
}

\begin{abstract}
Previous studies addressing functional aspects of nuclear factor $\kappa B(N F-\kappa B)$ activation in normal and transformed keratinocytes revealed complex and seemingly contradictory roles of this transcription factor in this cell type. In normal skin, NF- $\kappa$ B signaling seems to inhibit squamous cell carcinoma development whereas, in squamous cell carcinoma themselves, deregulated NF- $\kappa$ B expression and/or signaling is frequently observed. To further investigate this paradox, we focused on NF- $\kappa B$ activation as it relates to the transformed phenotype of immortalized but nontumorigenic human keratinocytes (HaCaT cells). We observed that NF- $\kappa$ B activity contributed to survival and growth of cultured HaCaT keratinocytes as shown by use of pharmacologic NF- $\kappa$ B inhibitors, RNA interference, and inducible overexpression of a dominant interfering I $\kappa B$ construct. NF- $\kappa$ B activation was largely provided through interaction with extracellular matrix components because preventing cell attachment by forced suspension culture markedly reduced NFKB signaling associated with cell death (anoikis); conversely, anoikis was partially reversed by NF- $\kappa$ B activation induced either by tumor necrosis factor- $\alpha$ treatment or by overexpressing the NF- $\kappa$ B p65 subunit in HaCaT cells. Furthermore, overexpression of NF- $\kappa$ Bp65 in HaCaT cells induced colony formation in soft agar and tumorigenicity in nude mice. In summary, as opposed to normal keratinocytes, immortalized HaCaT keratinocytes provide a cellular context in which deregulated NF- $\kappa$ B signaling supports multiple malignant traits in vitro and in vivo. (Cancer Res 2006; 66(10): 5209-15)
\end{abstract}

\section{Introduction}

The transcription factor nuclear factor $\kappa \mathrm{B}(\mathrm{NF}-\kappa \mathrm{B})$ was first identified as a nuclear factor in B lymphocytes, which binds to the enhancer of the immunoglobulin $\kappa$ light chain. The NF- $\kappa B$ family contains several members including Rel A (p65), Rel B, c-Rel, p50

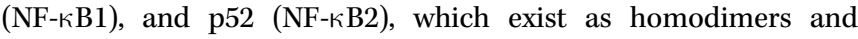
heterodimers retained by ankyrin domain-containing I $\kappa$ Bs in the cytoplasm of unstimulated cells (for review, see ref. 1). On stimulation of cells with inflammatory cytokines, IKB is phosphory-

Note: Supplementary data for this article are available at Cancer Research Online (http://cancerres.aacrjournals.org/).

Requests for reprints: Ulrich Rodeck, Department of Dermatology and Cutaneous Biology, Thomas Jefferson University, 233 South 10th Street, BLSB 409, Philadelphia, PA 19107. Phone: 215-503-5622; Fax: 215-503-5622; E-mail: ulrich.rodeck@mail.tju.edu and Adam P. Dicker, Department of Radiation Oncology, Thomas Jefferson University, 111 South 11th Street, Philadelphia, PA 19107. Phone: 215-955-6527; Fax: 215-955-0412; E-mail: adam.dicker@mail.tju.edu.

(C)2006 American Association for Cancer Research.

doi:10.1158/0008-5472.CAN-05-4158 lated by I $\mathrm{KB}$ kinases, ubiquitinated, and proteasomally degraded. Dissociation from I $\kappa \mathrm{B}$ enables nuclear translocation of $\mathrm{NF}-\kappa \mathrm{B}$ dimers where they direct transcription of a host of target genes, many of which encode antiapoptotic proteins. In addition to their roles in immune and inflammatory processes, NF- $\kappa \mathrm{B}$ family members have been observed to have oncogenic properties (2). Consistent with important roles of $\mathrm{NF}-\kappa \mathrm{B}$ in tumorigenesis, enhanced NF- $\kappa \mathrm{B}$ activity has been observed in malignant tumors of diverse origin including carcinomas (for review, see ref. 3).

Investigations into the role of NF- $\kappa \mathrm{B}$ in normal epidermis and the development of squamous cell carcinomas of the skin or mucous membranes revealed complex and seemingly contradictory roles of this transcription factor. As in other epithelial malignancies, deregulated NF- $\kappa$ B signaling is well documented in squamous cell carcinomas (4-6). Yet, when NF- $k B$ signaling is disrupted in normal epidermis, squamous cell carcinomas develop at increased rates $(7,8)$. The present study was undertaken to probe the relevance of NF- $\kappa$ B signaling to the malignant phenotype of nontumorigenic human epidermal keratinocytes representing early stages of malignant transformation (HaCaT; ref. 9). We describe that NF- $\kappa \mathrm{B}$ activation through interaction with extracellular matrix components provided an important survival mechanism to $\mathrm{HaCaT}$ cells that was disrupted by preventing cell attachment to extracellular matrix by forced suspension culture. Reduced NF- $\kappa$ B signaling and cell death in forced suspension culture could be partially reversed by tumor necrosis factor- $\alpha$ $(\mathrm{TNF} \alpha)$-induced NF- $\kappa \mathrm{B}$ activation. Deregulated NF- $\kappa \mathrm{B}$ signaling achieved by overexpressing the NF- $\kappa$ B p65 subunit similarly increased survival of HaCaT cells in forced suspension culture, induced colony formation in soft agar, and resulted in tumorigenicity of HaCaT cells in nude mice. These observations underscore that molecular alterations incurred during immortalization of HaCaT keratinocytes have conferred oncogenic properties to deregulated NF- $\kappa \mathrm{B}$ signaling. This is in clear contrast to normal keratinocytes in which NF- $\kappa$ B activation inhibits proliferation and reduces the propensity of malignant transformation $(7,10,11)$.

\section{Materials and Methods}

Cell lines and culture conditions. Immortalized human keratinocytes (HaCaT) and derivative cells were maintained in culture medium (W489) supplemented with $2 \%$ FCS as previously described (12). HaCaTp65 cells stably expressing the $\mathrm{COOH}$-terminally hemagglutinin-tagged human NF- $\kappa B$ p65 subunit were selected using $1 \mu \mathrm{g} / \mathrm{mL}$ puromycin. Selection of antibiotic-resistant cells started 48 hours after transfection with NF- $\kappa$ Bp65pIRESpuro2 vector (BD BioSciences, Palo Alto, CA) and continued until resistant colonies appeared. In this vector, both the NF-kBp65 gene and the puromycin resistance gene are expressed from one bicistronic mRNA, in which the internal ribosomal entry site of the encephalomyocarditis virus permits translation of the puromycin $\mathrm{N}$-acetyltransferase coding region downstream of the NF- $\mathrm{B}$ B 65 gene. Because all the surviving colonies 
expressed the transgene, there was no need for clonal selection, but rather all the puromycin-resistant clones were pooled and cultured under selective condition. Using this protocol, individual clonal variations are eliminated. Two independent transfections and selections were made generating two separate NF- $\kappa$ Bp65-overexpressing cell lines exhibiting similar phenotypic characteristics. The I $\kappa B \alpha$ superrepressor gene tagged at the $\mathrm{COOH}$ terminus with hemagglutinin (Upstate Biotechnology, Lake Placid, NY) was cloned into the tetracycline regulatable episomal expression vector pCEPTetP as previously described by us (13). The vector was transfected into the HaCaT-tTAl cell line expressing the tetracycline-controlled transactivator (13) and hygromycin-resistant colonies were pooled. Unless noted otherwise, all experiments were done in serum-free, growth factorfree KGM medium formulated for keratinocyte growth (13).

RNA interference. Small interfering RNA (siRNA) targeted to downregulate NF- $\mathrm{B}$ B65 mRNA (siGENOME SMARTpool siRNA, Dharmacon, Lafayette, CO) was transfected into HaCaT cells using RNAiFECT reagent (Qiagen, Valencia, CA) according to the protocol of the manufacturer. Nonsense siRNA provided by the manufacturer was used as a negative control. Cell lysates were collected at 24,48 , and 72 hours posttransfection.

Antibodies and immunoblot analyses. Immunoblot analyses were done using standard procedures as previously described by us (13). Antibodies to

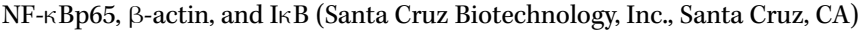
were used at $1 \mu \mathrm{g} / \mathrm{mL}$. The antibody against $\alpha$-tubulin (Calbiochem, San Diego, CA) was used at $1 \mu \mathrm{g} / \mathrm{mL}$. The antibody against cleaved poly(ADP-ribose) polymerase (PARP; Cell Signaling, Beverly, MA) was used at 1:1,000 dilution. Goat anti-rabbit secondary antibody (IRDye $800 \mathrm{CW}$, Rockland Inc., Gilbertsville, PA) and goat anti-mouse secondary antibody (Alexa Fluor 680, Molecular Probes, Eugene, OR) for Odyssey IR imaging were used at 1:10,000 and 1:2,000 dilutions, respectively. Signal analysis was done either by film exposure or digitally by scanning membranes with the Odyssey IR imaging system (Li-Cor Biosciences, Lincoln, NE).

3-(4,5-Dimethylthiazol-2-yl)-2,5-diphenyltetrazolium bromide assay. Subconfluent HaCaT cells were trypsinized and reseeded onto cell culturetreated 96-well plates in serum-free, growth factor-free KGM in the presence and absence of NF- $\mathrm{B}$ inhibitor Bayl1-7082 (5 $\mu \mathrm{mol} / \mathrm{L}$; Biomol, Plymouth Meeting, PA). Culture medium was exchanged to fresh growth medium (W489 containing 2\% FCS) 24 hours after seeding. 3-(4,5Dimethylthiazol-2-yl)-2,5-diphenyltetrazolium bromide (MTT) assays were done 3 days later by incubating cultures with MTT solution (Sigma, St. Louis, MO) at $37^{\circ} \mathrm{C}$ for 4 hours. MTT solubilization solution (10\% Triton $\mathrm{X}-100 / 0.1 \mathrm{~N}$ HCL in isopropanol) was added and the tissue culture plates were incubated for additional 12 hours at $37^{\circ} \mathrm{C}$ before absorbance was spectrophotometrically assessed at $570 \mathrm{~nm}$ (reference wavelength, $690 \mathrm{~nm}$ ).

Caspase-3 activity assay. For the caspase- 3 substrate cleavage assay, cells were processed and assayed using the EnzCheck Caspase-3 Assay Kit (Molecular Probes). Fluorescence was measured at emission and excitation settings of 485/530 nm with a Bio-Tek FL600 plate reader (Winooski, VT).

Anchorage-independent survival assay. Anchorage-independent cell survival was assessed as previously described (13). Briefly, tissue culture plates were coated with $0.9 \%$ agarose in serum-free medium. HaCaT cells were seeded on top of the agarose layer in serum-free KGM $(1.5 \mathrm{~mL} /$ well $)$ at $2 \times 10^{5} / \mathrm{mL}$. Twenty-four hours later, $600-\mu \mathrm{L}$ aliquots of cell solution were transferred to cell culture-treated plastic and supplemented with fresh media (W489 with $2 \%$ FCS). After 24 hours, reattached cells were fixed with $70 \%$ ethanol for 5 minutes. Cells were stained with crystal violet solution $(0.2 \%$ in methanol), rinsed with water, and air-dried.

NF-KB DNA binding assay. Subconfluent $\mathrm{HaCaT}$ cells were trypsinized and seeded in serum-free medium $\left(6 \mathrm{~mL} ; 4 \times 10^{5}\right.$ cells $\left./ \mathrm{mL}\right)$ in $100-\mathrm{mm}$ plates precoated with $0.9 \%$ agarose with or without TNF $\alpha(1 \mu \mathrm{g} / \mathrm{mL})$. Cells were collected for nuclear extract preparation after various times in forced suspension culture (4, 8, and 24 hours). For comparison, nuclear extracts were also prepared immediately after trypsinization of $\mathrm{HaCaT}$ cells. DNA binding of NF- $\kappa B$ was determined using the NF- $\mathrm{B}$ p50/p65 Transcription Factor Assay (Chemicon International, Temecula, CA) according to the instructions of the manufacturer. Briefly, nuclear extracts were prepared and incubated with double-stranded biotinylated oligonucleotides containing consensus NF- $\kappa \mathrm{B}$ binding sequences. NF- $\kappa \mathrm{B} / \mathrm{DNA}$ complexes were captured on 96-well plates coated with streptavidin. NF- $\kappa$ B bound to DNA was detected colorimetrically $(450 / 650 \mathrm{~nm})$ after sequential incubation with an antibody against NF-KBp65 and horseradish peroxidase-conjugated secondary antibody.

NF- $\kappa$ B reporter (secreted alkaline phosphatase) assay. Cells were seeded at $7.5 \times 10^{4} / \mathrm{mL}$ in KGM for 1 to 2 days before cotransfection with pSEAP2-NF- $\kappa$ B vector (BD BioSciences) encoding a secreted form of human placental alkaline phosphatase driven by a NF- $\mathrm{B}$ B-responsive promoter and a $\beta$-galactosidase expression vector (14) for control purposes. NF-KBdependent transcription was determined 48 hours after transfection using the Great EscAPe SEAP Reporter System 3, which is based on detection of secreted alkaline phosphatase in cell supernatants normalized to $\beta$-galactosidase activity using the luminescent $\beta$-gal detection kit (BD Biosciences).

Soft agar colony formation assay. Growth and survival of HaCaT cell variants was determined as previously described (15). Briefly, cells growing in monolayer culture were trypsinized and resuspended $\left(10^{4}\right.$ cells) in $2 \mathrm{~mL}$ medium containing $0.4 \%$ agar and $10 \%$ FCS. Cell suspensions were added to $0.6 \%$ agar layers in six-well plates. Wells examined immediately after plating showed only single cells. Soft agar colonies of $>50$ cells were scored after 14 days in triplicate.

Tumorigenicity of HaCaT variants in nude mice. HaCaT, HaCaTII-4, and HaCaTp65 single-cell suspensions were injected s.c. into the right hind limbs $\left(5 \times 10^{6}\right.$ for HaCaTII- 4 and $1 \times 10^{7}$ for other cell lines in $100 \mu \mathrm{L}$ PBS $)$ of 8-week-old athymic NCR NUM mice (Taconic Farms, Hudson, NY). Tumor growth was monitored every 2 days for 2 months. Tumor volume was determined by direct measurement with calipers and calculated by the formula [(smallest diameter ${ }^{2} \times$ widest diameter) / 2]. Tumors that grew $>500 \mathrm{~mm}^{3}$ and did not regress were considered to be established tumors. Tumors were not allowed to grow beyond $2,000 \mathrm{~mm}^{3}$ in accordance with Institutional Animal Care and Use Committee regulations.

Immunohistochemical analyses. Paraffin-embedded blocks containing the mouse tumor tissue were fixed in $10 \%$ neutral-buffered formalin and processed for H\&E staining and immunohistochemical analysis. Tissue sections were deparaffinized in xylene, rehydrated in ethanol, rehydrated with water, and washed in $1 \%$ PBS. Primary antibodies (HA-Tag, Cell Signaling; NFKB, Santa Cruz Biotechnology) were applied to slides and incubated for 45 to 60 minutes. The immune complexes were visualized with the chromogenic substrate Dako Liquid DAB+ Substrate-Chromogen Solution (diaminobenzidine tetrahydrochloride, K3468, DAKO, Carpinteria, CA) for 5 minutes.

\section{Results}

NF- $\kappa$ B activation contributes to survival of immortalized keratinocytes in steady-state culture conditions. NF- $\kappa \mathrm{B}$ signaling has recently been shown to support survival of immortalized mammary epithelial cells in three-dimensional tissue reconstructs $(16,17)$. Here we assessed whether NF- $\kappa \mathrm{B}$ signaling similarly contributed to the survival of immortalized human epidermal keratinocytes. To this end, we first used the NF- $\kappa \mathrm{B}$ inhibitor Bayl17082 in immortalized human keratinocytes (HaCaT). Bay11-7082 efficiently decreased transcriptional NF- $\kappa \mathrm{B}$ activity in HaCaT keratinocytes (Fig. 1A). Consistent with an important role of NF- $\kappa \mathrm{B}$ in HaCaT cell proliferation or survival, we observed that, within 24 hours of Bayl1-7082 addition, metabolic activity of HaCaT cells was markedly reduced as determined by MTT assay (Supplementary Fig. S1). Similar results were obtained when using other inhibitors of NF- $\kappa \mathrm{B}$ activity (i.e., the proteasome inhibitor MG-132 and parthenolide; Supplementary Fig. S1). Inhibition of MTT conversion was associated with extensive membrane blebbing and nuclear condensation (not shown) and with p85PARP cleavage (Fig. $1 A$ ), consistent with caspase-3 activation and apoptotic cell death. To obtain independent evidence for a role of NF- $\kappa$ B in HaCaT cell survival, we assessed the effects of down-regulating the 


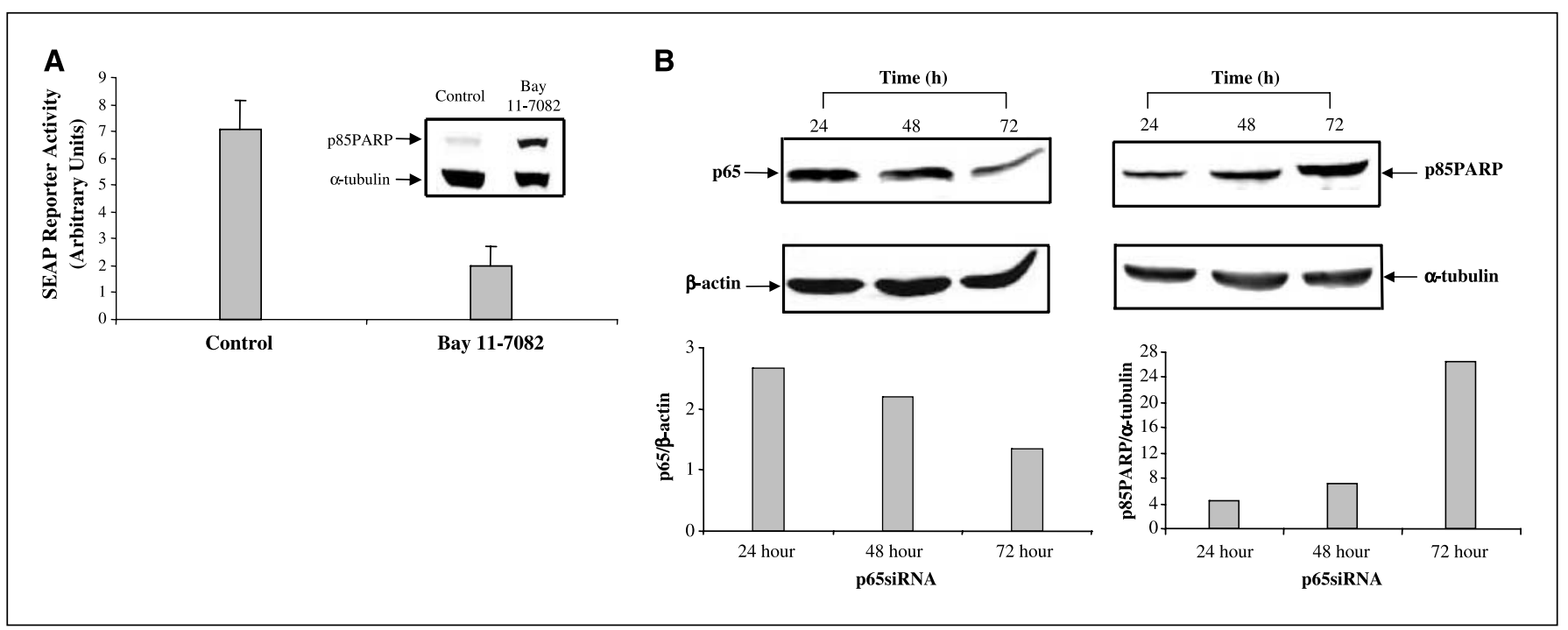

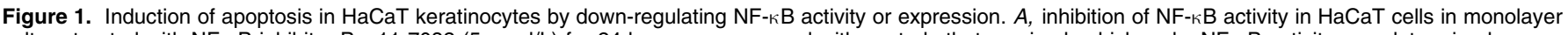

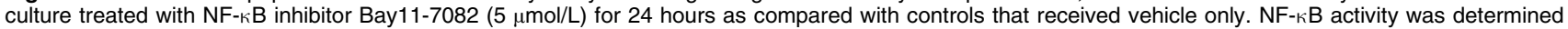
using the Great EscAPe SEAP Reporter System 3 as described in Materials and Methods. Columns, mean of three independent experiments; bars, SD. $P<0.05$, Student's $t$ test. Inset, apoptosis induction in HaCaT cells by treatment with Bay11-7082. Cell extracts were prepared 24 hours after Bay11-7082 was added and caspase- 3 activity assessed by detection of the caspase- 3 cleavage product of PARP. For control purposes, blots were rehybridized with an antibody to $\alpha$-tubulin. $B$, time-dependent changes in expression of NF-kBp65 and the p85PARP cleavage product in siRNA-treated cells. Densitometric representation of the immunoblot results relative to expression of $\beta$-actin or $\alpha$-tubulin as indicated.

expression of the NF-kB p65 subunit in HaCaT cells by way of siRNA (Fig. $1 B$ ). As expected, transfection of NF- $\kappa$ Bp65-targeted siRNA was associated with reduced expression of the NF- $\kappa$ Bp65 protein and increased PARP cleavage. To further test the role of NF- $\kappa \mathrm{B}$ activation in HaCaT cell survival, we transfected these cells with a

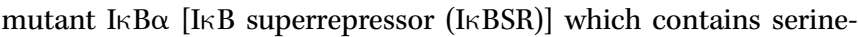
to-alanine mutations at amino acids 32 and 36 . The IkBSR construct is resistant to IKK-dependent phosphorylation, ubiquitination, and proteasomal degradation, and serves to inhibit NF- $\kappa \mathrm{B}$-dependent transactivation by sequestering NF- $\mathrm{B}$ in the cytoplasm (18). Attempts at stable, constitutive expression of this construct failed (not shown), necessitating the use of a previously established inducible expression system (14). On removal of tetracycline from the medium, expression of the hemagglutinin-tagged I $\kappa$ BSR was efficiently induced (Fig. $2 A$ ). As expected, induced expression of the dominant interfering $\mathrm{I} \kappa \mathrm{B}$ resulted in markedly reduced $\mathrm{NF}-\kappa \mathrm{B}$ activity as assessed by transcription of a reporter gene driven by a NF- $\kappa$ B-responsive promoter (Fig. $2 B$ ). In addition, induced expression of I $\mathrm{BSR}$ resulted in enhanced apoptosis as determined by assessment of caspase- 3 activity in cell extracts collected at several time points after transgene induction (Fig. $2 C$ ). Of note, even in the noninduced state, slightly enhanced levels of caspase-3-dependent substrate cleavage were observed over time, perhaps due to leakiness of the expression construct. Taken together, these results underscore that $\mathrm{NF}-\kappa \mathrm{B}$ activation is an important requisite for survival of cultured $\mathrm{HaCaT}$ cells.

Extracellular matrix adhesion maintains NF- $\kappa$ B activation in HaCaT cells. Next, we asked whether matrix adhesion itself contributed to NF- $\kappa \mathrm{B}$ activity under steady-state culture conditions. This investigation was prompted by the observation that maintaining $\mathrm{HaCaT}$ cells in the absence of exogenous growth factors had only marginal effects on NF- $\kappa \mathrm{B}$ activity (not shown). To address this question, we placed $\mathrm{HaCaT}$ cells in forced suspension culture as previously described (13) and assayed $\mathrm{NF}-\kappa \mathrm{B}$ activity under those conditions for up to 24 hours. Consistent with an important role of matrix adhesion in maintaining $\mathrm{NF}-\kappa \mathrm{B}$ activity in HaCaT cells, we observed a continuous decrease in NF- $\kappa \mathrm{B}$ activity over the observation period (Fig. $3 A$ ).

TNF- $\alpha$ treatment rescues NF- $\kappa$ B activity and enhances HaCaT cell survival in forced suspension culture. The results described above raised the question whether inflammatory cytokines known to stimulate NF- $\mathrm{B}$ activity can supplant the requirement for extracellular matrix adhesion for NF- $\kappa \mathrm{B}$ activation in the suspended state. Among such cytokines, TNF- $\alpha$ is one of the strongest NF- $\kappa \mathrm{B}$ activators (1). We therefore determined whether $\mathrm{TNF}-\alpha$ treatment counteracted the reduction of NF- $\kappa \mathrm{B}$ activity incurred by $\mathrm{HaCaT}$ cells in forced suspension culture. Consistent with this notion, we observed attenuated reduction of NF- $\kappa$ B activity in suspended cells in the presence of TNF- $\alpha$ (Fig. 3A). This observation led us to assess the effect of TNF- $\alpha$ addition on survival of HaCaT cells in suspension culture. In agreement with an important role of NF- $\kappa \mathrm{B}$ activity in HaCaT cell survival, rescue of $\mathrm{NF}-\kappa \mathrm{B}$ activity by TNF- $\alpha$ treatment was associated with enhanced survival of HaCaT cells in forced suspension culture (Fig. $3 B$ ). This was determined by assessing colony formation of HaCaT cells reseeded on cell culture-treated plastic after 24 hour of forced suspension culture. As compared with untreated controls, TNF- $\alpha$ treatment during suspension increased both the number and size of colonies. Specifically, the number of colonies in the presence of TNF- $\alpha$ was consistently increased by $40 \%$ whereas treatment with epidermal growth factor increased colony formation by $130 \%$ as described previously (Fig. $3 C$; ref. 13). As expected, the survival advantage conferred by TNF- $\alpha$ addition was drastically attenuated by addition of the NF- $\kappa$ B inhibitor Bayl1-7082. Because TNF- $\alpha$ is known to induce apoptosis in certain cell systems and to avoid such proapoptotic effect of TNF- $\alpha$, we initially included caspase 8 inhibitors in the experiments probing the effects of TNF- $\alpha$ on $\mathrm{HaCaT}$ cell survival in forced suspension. However, the inclusion of such inhibitors was not necessary for TNF- $\alpha$ to exert its survival effect in forced suspension cultures. Collectively, these results 

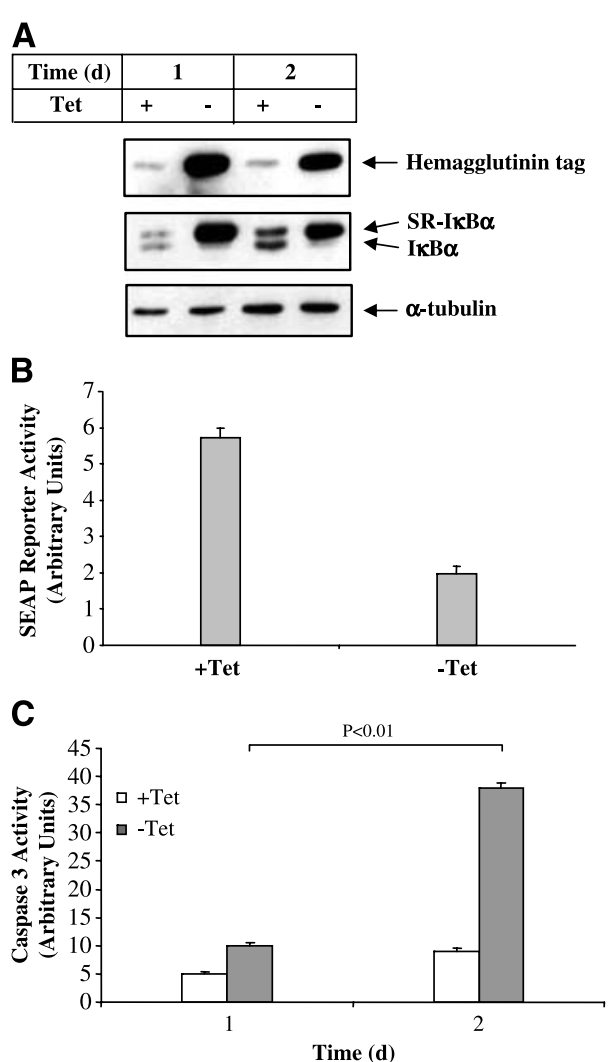

Figure 2. Inhibition of NF-kB activity by overexpressing of the $1 \kappa \mathrm{B} \alpha$ superrepressor induces apoptosis in $\mathrm{HaCaT}$ cells. $A$, expression of the $\mathrm{I}_{\kappa} \mathrm{Bo}$ superrepressor was induced in $\mathrm{HaCaT}$ cells by removal of tetracycline from culture media. Transgene expression was monitored by Western blot analysis of the hemagglutinin tag and I $\kappa \mathrm{B} \alpha \mathrm{SR}$ itself as indicated. $B$, NF- $\mathrm{B}$-dependent promoter activity in induced and uninduced $\mathrm{HaCaT}$ cells determined 24 hours after transgene induction using a reporter gene assay. Columns, mean of three independent experiments; bars, SD. $P<0.01$, Student's $t$ test. $C$, effect of $I_{\kappa} \mathrm{B} \alpha$ superrepressor expression on $\mathrm{HaCaT}$ cells survival. Apoptosis induction by $I_{\kappa} \mathrm{B} \alpha$ superrepressor expression is evident by measuring caspase- 3 activity using a fluorogenic substrate as described in Materials and Methods.

assigned an unexpected new role to TNF- $\alpha$ in support of anchorage-independent epithelial cell survival.

Deregulated NF- $\kappa$ B signaling supports anchorage-independent HaCaT cell survival. To independently test whether TNF- $\alpha$-mediated HaCaT cell survival in forced suspension culture could be accomplished through up-regulating NF- $\kappa \mathrm{B}$ activity, we established HaCaT cells stably expressing the NF- $\kappa \mathrm{B}$ p65 subunit (Fig. 4A). As expected, these cells revealed increased constitutive NF- $\kappa B$ activity relative to mock-transfected cells. Furthermore, when subjected to forced suspension culture, these cells survived in markedly higher numbers when compared with controls (Fig. $4 B$ ). TNF- $\alpha$ treatment did not further enhance the rescue effect observed in NF- $\kappa$ Bp65-expressing $\mathrm{HaCaT}$ cells, in agreement with the notion that the TNF- $\alpha$ effect on HaCaT cell survival is primarily due to activation of NF- $\mathrm{B}$. Finally, and as expected, Bay11-7082 treatment drastically attenuated NF- $\kappa$ B activity (Supplementary Fig. S3) and survival of NF-кBp65 HaCaT cells in suspension culture (Fig. 4B).

Overexpression of NF- $\kappa$ Bp65 induces soft agar colony formation by HaCaT cells. The observation that deregulated $\mathrm{NF}-\kappa \mathrm{B}$ activity supported anchorage-independent survival of
HaCaT cells in liquid culture encouraged us to ascertain whether overexpression of NF- $\kappa$ Bp65 also affected colony formation in soft agar, an important parameter of advanced malignancy in cells derived from solid tumors. This analysis revealed that, consistent with earlier results $(9,19)$, mock-transfected HaCaT cells did not form soft agar colonies (Fig. 5). In contrast, NF- $\kappa$ Bp65-overexpressing $\mathrm{HaCaT}$ cells formed colonies, albeit to a lesser degree, than fully transformed Ha-RasV12-expressing HaCaTII-4 cells included as a positive control (19). This experiment was repeated with a second, independently derived p65-overexpressing HaCaT transfectant which also formed colonies in soft agar (data not shown).

Overexpression of NF- $\kappa$ Bp65 induces tumor formation of HaCaT cells in nude mice. Finally, we addressed the question whether NF- $\kappa$ Bp65 overexpression rendered HaCaT cells tumorigenic in immunodeficient mice. HaCaT cells do not form tumors when xenotransplanted to immunodeficient nude mice (19). In marked contrast, we observed that HaCaTp65 cells formed tumors in all six mice injected with $1 \times 10^{7}$ cells per mouse (Fig. 6) whereas mock-transfected control HaCaT cells did not. Expression of the NF- $\kappa$ Bp65 transgene in tumor tissues was confirmed in tumor cells in situ by immunostaining using antibodies to both the

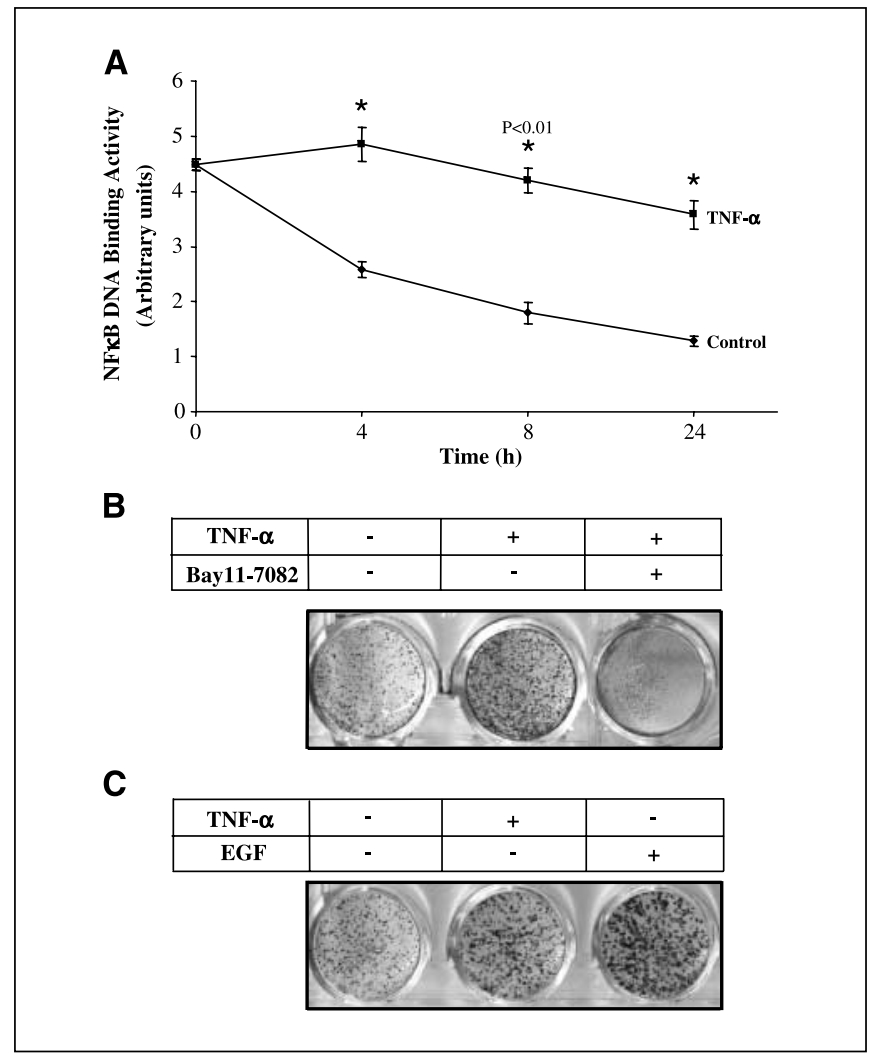

Figure 3. TNF- $\alpha$ enhances $\mathrm{HaCaT}$ cell survival in forced suspension culture through activation of NF-кB. A, HaCaT cells were suspended in plates precoated with $0.9 \%$ agarose in serum-free medium. NF- $k B$ activity was evaluated in cell extracts prepared at the time points indicated by assessing DNA binding of the active form of NF-kB in nuclear extracts as described in Materials and Methods. Treatment of suspended cells with TNF- $\alpha(10 \mathrm{ng} / \mathrm{mL})$ counteracted the gradual loss of NF-kB DNA binding activity observed in control cells. $B$, HaCaT cells were suspended in plates precoated with $0.9 \%$ agarose with or without TNF- $\alpha(10 \mathrm{ng} / \mathrm{mL})$ and the NF-kB inhibitor Bay11-7082 $(5 \mu \mathrm{mol} / \mathrm{L})$ as indicated for 24 hours. Aliquots of cells were reseeded in fresh medium on tissue culture-treated plastic. Crystal violet staining of reattached viable cells was done 24 hours later. $C$, comparison of the effects of EGF $(10 \mathrm{ng} / \mathrm{mL})$ and of TNF- $\alpha(10 \mathrm{ng} / \mathrm{mL})$ on HaCaT cell survival in forced suspension cultures. 


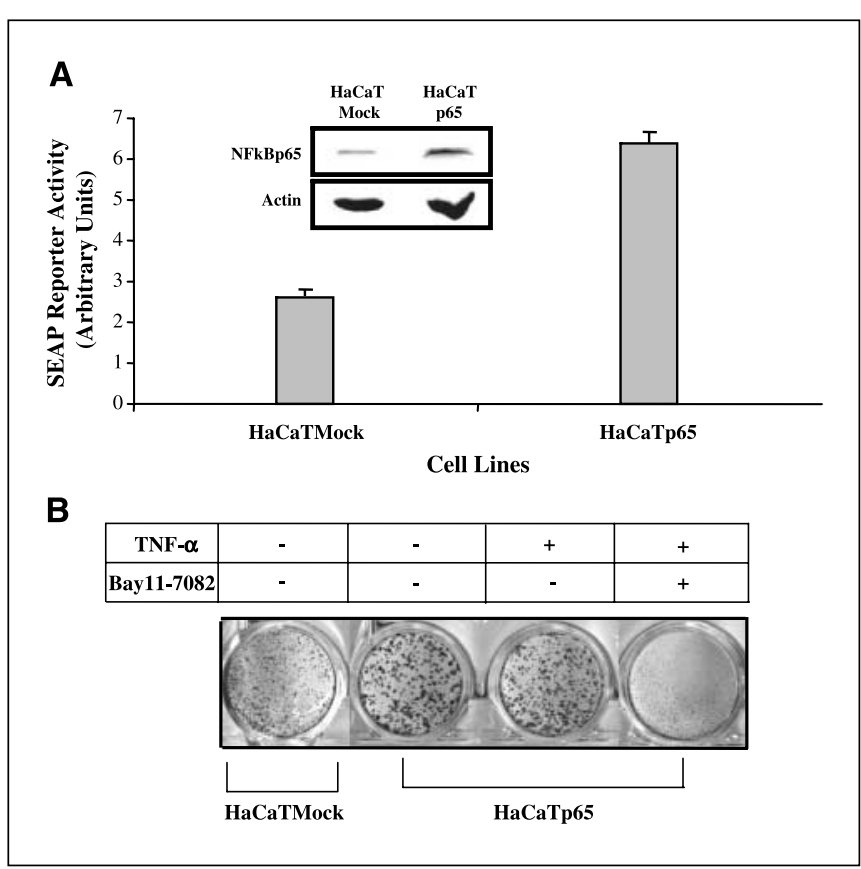

Figure 4. Overexpression of the NF-kB p65 subunit supports $\mathrm{HaCaT}$ cell survival in forced suspension culture. $A$, NF-kB promoter activity in $\mathrm{HaCaT}$ cells stably transfected with NF-kBp65 (HaCaTp65) as compared with parental HaCaT cells. Columns, mean of three independent experiments; bars, SD. $P<0.01$, Student's $t$ test. Inset, expression levels of NF-kBp65 in parental $\mathrm{HaCaT}$ and $\mathrm{HaCaTp} 65$ cells. $B$, enhanced survival in forced suspension culture of $\mathrm{HaCaTp} 65$ cells. Cells reseeded after 24 hours of forced suspension culture. Note that survival of $\mathrm{HaCaTp} 65$ cells was not further stimulated by TNF- $\alpha$ treatment and was markedly inhibited by NF-kB inhibitor Bay11-7082.

hemagglutinin tag and NF- $\kappa$ Bp65 itself (Supplementary Fig. S2). To confirm that NF- $\kappa$ Bp65 overexpression in HaCaT cells induces tumorigenicity in these cells, we used a second, independently derived p65-overexpressing HaCaT cell variant which also formed tumors (not shown). In these experiments, we used Ha-Rastransformed HaCaTII- 4 cells as a positive control; in contrast to HaCaT cells, HaCaTII- 4 cells have previously been described to be tumorigenic in nude mice when injected at $5 \times 10^{6}$ per mouse (19). We confirmed these earlier findings for both HaCaT and HaCaTII-4 cells, which were nontumorigenic and tumorigenic, respectively. HaCaTII- 4 cells formed tumors in three of six inoculated mice. HaCaTII-4 tumors presented as moderate to poorly differentiated squamous cell carcinomas (Fig. 6). These tumors grew in broad sheets and without significant keratin production. Numerous mitotic figures were present and cell borders were well delineated with intercellular bridges. By contrast, HaCaTp65 tumors represented well-differentiated squamous cell carcinomas with abundant eosinophilic cytoplasm, consistent with keratin production. In comparison with HaCaTII-4 tumors, only rare mitotic figures were present in HaCaTp65 tumors along the periphery of the neoplastic lesions. In addition, neutrophils and, to a lesser extent, lymphocytes were prominent within the tumor and at the tumor/ stromal interface. Collectively, these data revealed that overexpression of NF- $\kappa$ Bp65 in $\mathrm{HaCaT}$ cells was associated with tumor formation in vivo and with inflammatory infiltrates.

\section{Discussion}

This study presents multiple lines of evidence in support of oncogenic properties of $\mathrm{NF}-\kappa \mathrm{B}$ in an epidermal cell line representing an early stage of squamous cell carcinoma development. Perhaps most importantly, overexpression of the NF- $\kappa$ B p65 subunit in immortalized HaCaT keratinocytes induced soft agar colony formation and tumorigenicity in immunodeficient mice; these are canonical criteria for full malignant transformation of solid tumor cells. In addition, the results presented here assign a role to $\mathrm{TNF}-\alpha$-induced $\mathrm{NF}-\kappa \mathrm{B}$ signaling in survival of $\mathrm{HaCaT}$ cells, particularly in the anchorage-independent state. This result is consistent with the earlier observation that mice deficient in TNF- $\alpha$ exhibit greatly reduced rates of carcinogen-induced skin tumor formation (20). Collectively, our results support the notion that deregulated NF- $\kappa$ B signaling, as observed in squamous cell carcinomas, supports several aspects of the malignant phenotype in this cell type.

However, our results seem to be in stark contrast to the wellcharacterized role of $\mathrm{NF}-\kappa \mathrm{B}$ as a tumor suppressor in normal murine and human keratinocytes. Notably, down-regulating NF- $\kappa$ B activity by targeted overexpression of the I $\kappa$ BSR in mouse epidermis is associated with epidermal hyperproliferation and increased rates of squamous carcinoma development (8) and NF- $\kappa$ B exerts growth inhibitory effects on normal mouse keratinocytes $(10,21)$. Similarly, abrogating NF- $\kappa \mathrm{B}$ activity in human skin reconstructs xenotransplanted to mice leads to hyperproliferation and epidermal neoplasia (7). In light of this previous evidence, our data support the concept that immortalized epidermal keratinocytes at early stages of malignant transformation have accrued molecular alterations that enable a "switch" of NF- $\kappa \mathrm{B}$ function from being a tumor suppressor to being a tumor promoter as recently proposed by Perkins (22) and Aggarwal (3).

Whereas tumor initiation usually involves inactivation of tumor suppressor genes, later stages of tumor development are frequently driven by oncogenes. It is presently unknown which initiating events have occurred in $\mathrm{HaCaT}$ keratinocytes that create permissive conditions for $\mathrm{NF}-\kappa \mathrm{B}$ to promote tumorigenicity of these cells. However, it is known that key tumor suppressors are altered in HaCaT cells. This includes increased telomerase activity (23), mutational inactivation of both alleles of p53 (24), silencing of p16INK4A expression by promoter methylation (25), and defective regulation of either p21 expression or function $(26,27)$. Consistent with earlier reports $(23,28)$, we found p21Wafl/Cipl

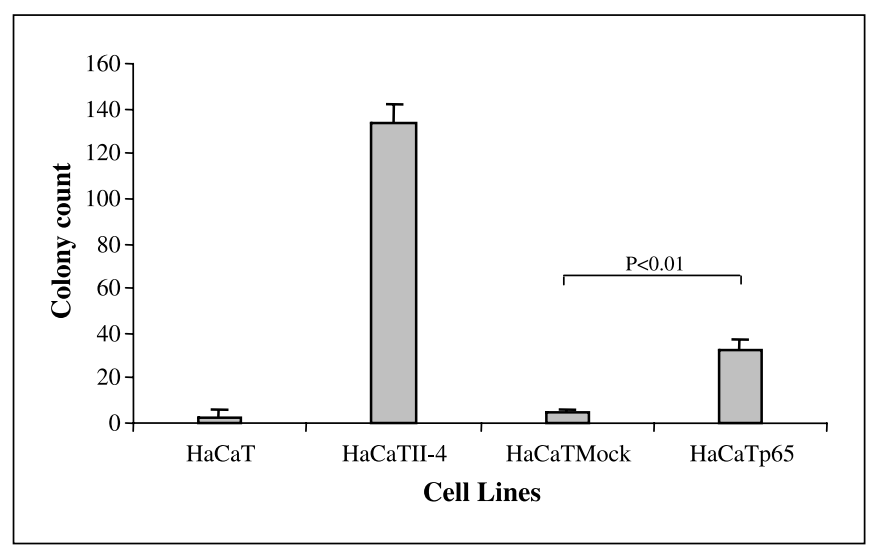

Figure 5. Overexpression of NF-kBp65 in $\mathrm{HaCaT}$ cells induces soft agar colony formation. Survival and growth of $\mathrm{HaCaT}$, HaCaTII-4, HaCaTMock, and HaCaTp65 cells in soft agar was determined as described in Materials and Methods. Soft agar colonies of $>50$ cells were scored at 14 days in triplicate samples. Columns, mean of three independent experiments producing comparable results; bars, SD. $P<0.01$, Student's $t$ test. 


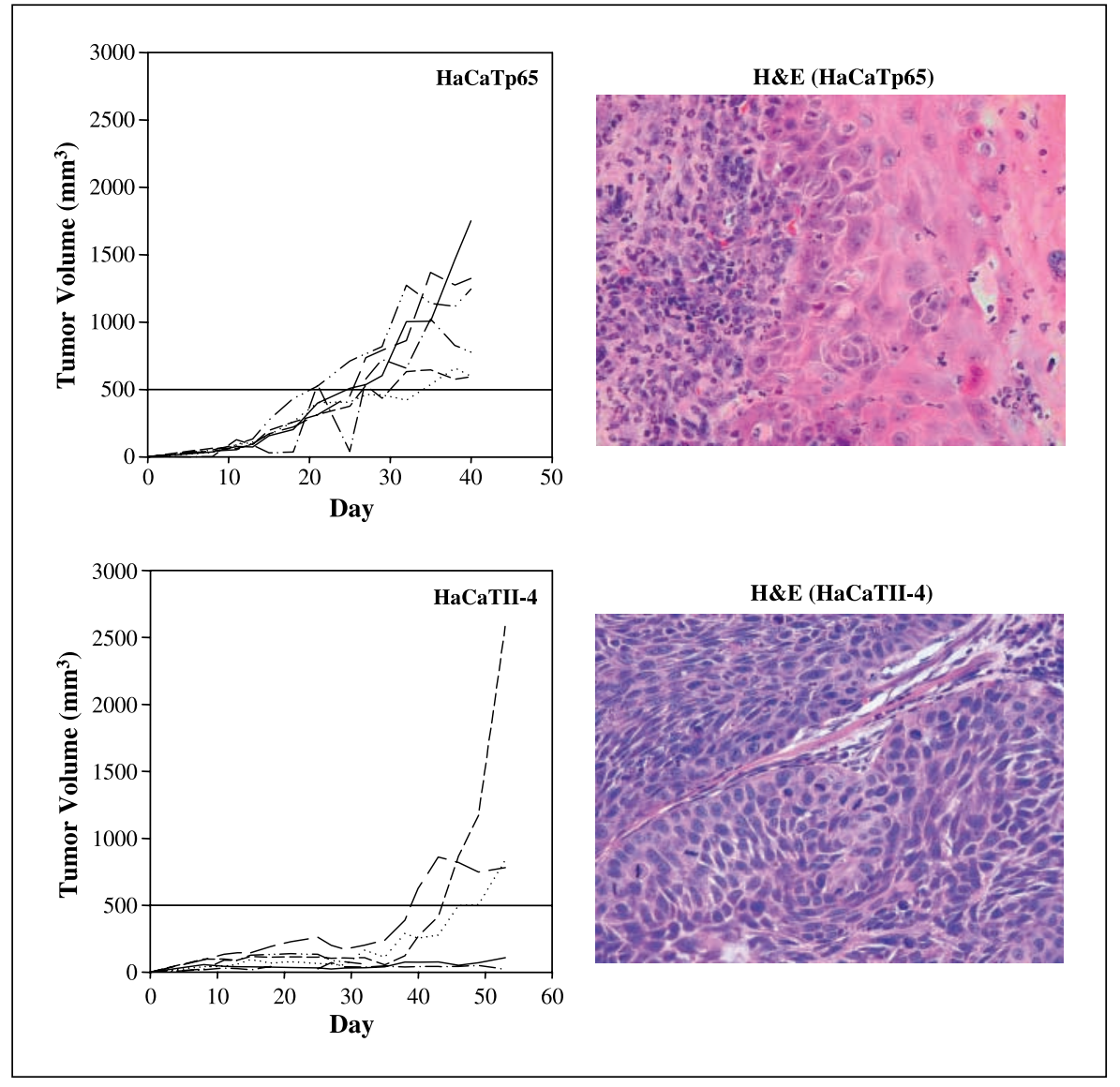

Figure 6. In vivo tumorigenicity of $\mathrm{HaCaT}$ keratinocytes overexpressing NF-kBp65. Single-cell suspensions of $\mathrm{HaCaT}$ cell variants were injected into the flanks of immunodeficient nude mice. HaCaTp65 and $\mathrm{HaCaTII}-4$ tumor volumes were determined using calipers and calculated [(smallest diameter ${ }^{2} \times$ widest diameter) / 2] every 2 days for 2 month. Paraffin-embedded blocks containing HaCaTp65 and $\mathrm{HaCaTII}-4$ tumors were processed for H\&E staining.

protein not to be expressed in either HaCaT cells or HaCaTp65 cells under steady-state culture conditions. ${ }^{4}$ Thus, as p21/Wafl/ Cipl is a target gene for NF- $\kappa \mathrm{B}$ in normal keratinocytes, it may contribute to growth arrest on NF- $\mathrm{B}$ activation in this cell type (29) but not in HaCaT cells (23). It remains to be determined whether loss of p21/Waf1/Cip1 expression, as observed in HaCaT cells, is sufficient for the manifestation of oncogenic properties of NF $-\kappa B$ activation. Alternatively, loss of either p53 or pl6INK4A/ $\mathrm{ADP}$ ribosylation factor (ARF) function in HaCaT cells may have unmasked transcriptional properties of NF- $\kappa \mathrm{B}$ normally suppressed by p53 and/or $\operatorname{ARF}(22,30)$. Additional studies are necessary to define the functional importance of NF- $\kappa$ B-dependent growth constraints in epidermal keratinocytes in preventing the emergence of malignant cells in the differentiating epidermis.

To our knowledge, this is the first report of tumorigenic conversion of HaCaT keratinocytes by overexpression of a single proto-oncogene. Previous work by the Fusenig group has shown that forced expression of oncogenic Ha-RasV12 was similarly capable of inducing tumorigenicity of HaCaT cells in experimental mice (19), a result confirmed in the present study using HaCaTII4 cells. In contrast to HaCaTII-4 tumors, HaCaTp65 tumors revealed marked infiltration with inflammatory cells. Previous studies have implicated both tumor cell-autonomous effects of NF- $\kappa$ B signaling $(31,32)$ and "field effects" by chronic inflammation (32) in NF- $\mathrm{B}$ driven epithelial tumor formation. However,

\footnotetext{
${ }^{4}$ M.R.D. Quadros and U. Rodeck, unpublished results.
}

in the case of HaCaTp65 tumors, the inflammatory infiltrate may, at least in part, be caused by excessive keratin deposition in HaCaTp65 tumors. Regardless of the relative contribution of the inflammatory response to tumorigenicity in mice, persistent overexpression of NF- $\mathrm{Bp} 65$ in $\mathrm{HaCaT}$ cells was clearly associated with tumor cell-autonomous roles of NF- $\kappa \mathrm{B}$ activation, in support of epithelial cell survival and colony formation in soft agar. Thus, it seems likely that NF- $\kappa$ B signaling contributes in a tumor cellautonomous fashion to the development and progression of hepatomas (31), colorectal carcinomas (32), and, as shown here, squamous cell carcinomas.

In summary, these results establish that deregulated NF- $\mathrm{B}$ signaling exerts powerful oncogenic effects in an immortalized keratinocyte line. They lend support to the notion that NF-кB activity serves opposite roles in squamous cell carcinoma development, depending on tumor progression stage. Whereas NF- $\mathrm{B}$ activation seems to curb transformation of normal uninitiated keratinocytes, it exacerbates the malignant phenotype of initiated, immortalized keratinocytes such as HaCaT cells.

\section{Acknowledgments}

Received 11/21/2005; revised 2/21/2006; accepted 3/9/2006.

Grant support: U.S. NIH grants CA106633 (A.P. Dicker) and CA81008 (U. Rodeck) and Department of Defense grant DAMD-17-02-1-0216 (U. Rodeck).

The costs of publication of this article were defrayed in part by the payment of page charges. This article must therefore be hereby marked advertisement in accordance with 18 U.S.C. Section 1734 solely to indicate this fact.

We thank Dr. N. Fusenig (Division of Carcinogenesis and Differentiation, German Cancer Research Center, Heidelberg, Germany) for providing HaCaT cells, and Yaping Sui, William R. Davidson, and Stephanie Lavorgna for technical assistance. 


\section{References}

1. Karin M, Ben-Neriah Y. Phosphorylation meets ubiquitination: the control of NF- $\kappa \mathrm{B}$ activity. Annu Rev Immun 2000;18:621-63.

2. Luque I, Gelinas C. Rel/NF- $\kappa$ B and $\mathrm{I} \kappa \mathrm{B}$ factors in oncogenesis. Semin Cancer Biol 1997;8:103-11.

3. Aggarwal BB. Nuclear factor- $\kappa B$ : the enemy within. Cancer Cell 2004;6:203-8.

4. Duffey DC, Chen Z, Dong G, et al. Expression of a dominant-negative mutant inhibitor- $\kappa \mathrm{B} \alpha$ of nuclear factor- $\kappa \mathrm{B}$ in human head and neck squamous cell carcinoma inhibits survival, proinflammatory cytokine expression, and tumor growth in vivo. Cancer Res 1999;59:3468-74.

5. Loercher A, Lee TL, Ricker JL, et al. Nuclear factor-kB is an important modulator of the altered gene expression profile and malignant phenotype in squamous cell carcinoma. Cancer Res 2004;64:6511-23.

6. Aggarwal S, Takada Y, Singh S, Myers JN, Aggarwal BB. Inhibition of growth and survival of human head and neck squamous cell carcinoma cells by curcumin via modulation of nuclear factor- $\kappa \mathrm{B}$ signaling. Int $\mathrm{J}$ Cancer 2004;111:679-92.

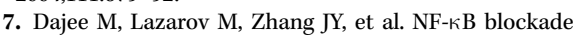
and oncogenic Ras trigger invasive human epidermal neoplasia. Nature 2003;421:639-43.

8. van Hogerlinden M, Rozell BL, Ahrlund-Richter L, Toftgard R. Squamous cell carcinomas and increased apoptosis in skin with inhibited Rel/nuclear factor-kB signaling. Cancer Res 1999;59:3299-303.

9. Boukamp P, Petrussevska RT, Breitkreutz D, Hornung J, Markham A, Fusenig NE. Normal keratinization in a spontaneously immortalized aneuploid human keratinocyte cell line. J Cell Biol 1988;106:761-71.

10. Seitz CS, Deng H, Hinata K, Lin Q, Khavari PA. Nuclear factor $\kappa B$ subunits induce epithelial cell growth arrest. Cancer Res 2000;60:4085-92.

11. Seitz CS, Freiberg RA, Hinata K, Khavari PA. NF- $k B$ determines localization and features of cell death in epidermis. J Clin Invest 2000;105:253-60.

12. Jost M, Huggett TM, Kari C, Boise LH, Rodeck U. Epidermal growth factor receptor-dependent control of keratinocyte survival and Bcl-xL expression through a MEK-dependent pathway. J Biol Chem 2001;276: 6320-6.

13. Jost M, Huggett TM, Kari C, Rodeck U. Matrix independent survival of human keratinocytes through an EGF receptor/MAPK-kinase-dependent pathway. Mol Biol Cell 2001;12:1519-27.

14. Jost M, Kari C, Rodeck U. An episomal vector for stable tetracycline-regulated gene expression. Nucleic Acids Res 1997;25:3131-4.

15. Stoker M, O'Neill C, Berryman S, Waxman V. Anchorage and growth regulation in normal and virustransformed cells. Int J Cancer 1968;3:683-93.

16. Weaver VM, Lelievre S, Lakins JN, et al. $\beta 4$ integrindependent formation of polarized three-dimensional architecture confers resistance to apoptosis in norma and malignant mammary epithelium. Cancer Cell 2002 2:205-16.

17. Zahir N, Lakins JN, Russell A, et al. Autocrine laminin-5 ligates $\alpha 6 \beta 4$ integrin and activates RAC and $\mathrm{NF} \kappa \mathrm{B}$ to mediate anchorage-independent survival of mammary tumors. J Cell Biol 2003;163:1397-407.

18. Wang CY, Mayo MW, Baldwin AS, Jr. TNF- $\alpha$ and cancer therapy-induced apoptosis: potentiation by inhibition of NF-кB. Science 1996;274:784-7.

19. Boukamp P, Stanbridge EJ, Foo DY, Cerutti PA, Fusenig NE. c-Ha-ras oncogene expression in immortalized human keratinocytes (HaCaT) alters growth potential in vivo but lacks correlation with malignancy. Cancer Res 1990;50:2840-7.

20. Moore RJ, Owens DM, Stamp G, et al. Mice deficient in tumor necrosis factor- $\alpha$ are resistant to skin carcinogenesis. Nat Med 1999;5:828-31.

21. Seitz CS, Lin Q, Deng H, Khavari PA. Alterations in NF- $\kappa \mathrm{B}$ function in transgenic epithelial tissue demonstrate a growth inhibitory role for NF- $\mathrm{B}$. Proc Natl Acad Sci U S A 1998;95:2307-12.

22. Perkins ND. NF- $\kappa B$ : tumor promoter or suppressor? Trends Cell Biol 2004;14:64-9.

23. Kallassy M, Martel N, Damour O, Yamasaki H, Nakazawa $\mathrm{H}$. Growth arrest of immortalized human keratinocytes and suppression of telomerase activity by
p21WAF1 gene expression. Mol Carcinogenesis 1998;21: 26-36.

24. Boukamp P, Peter W, Pascheberg U, et al. Step-wise progression in human skin carcinogenesis in vitro involves mutational inactivation of $\mathrm{p} 53$, $\mathrm{rasH}$ oncogene activation and additional chromosome loss. Oncogene 1995;11:961-9.

25. Chaturvedi V, Qin JZ, Denning MF, Choubey D, Diaz MO, Nickoloff BJ. Apoptosis in proliferating, senescent, and immortalized keratinocytes. J Biol Chem 1999;274: 23358-67.

26. Chaturvedi V, Qin JZ, Denning MF, Choubey D, Diaz MO, Nickoloff BJ. Abnormal NF- $\kappa$ B signaling pathway with enhanced susceptibility to apoptosis in immortalized keratinocytes. J Dermatol Sci 2001;26: 67-78.

27. Harvat BL, Jetten AM. Decreased growth inhibitory responses of squamous carcinoma cells to interferon- $\gamma$ involve failure to recruit cki proteins into cdk2 complexes. J Invest Dermatol 2001;117: 1274-81.

28. Facchinetti MM, De Siervi A, Toskos D, Senderowicz AM. UCN-01-induced cell cycle arrest requires the transcriptional induction of p21(wafl/cipl) by activation of mitogen-activated protein/extracellular signalregulated kinase kinase/extracellular signal-regulated kinase pathway. Cancer Res 2004;64:3629-37.

29. Basile JR, Eichten A, Zacny V, Munger K. 4 NF$\kappa \mathrm{B}$-mediated induction of $\mathrm{p} 2 \mathrm{l}(\mathrm{Cip} \mathrm{l} / \mathrm{Wafl})$ by tumo necrosis factor $\alpha$ induces growth arrest and cytoprotection in normal human keratinocytes. Mol Cancer Res 2003;1:262-70.

30. Rocha S, Garrett MD, Campbell KJ, Schumm K, Perkins ND. Regulation of NF-KB and p53 through activation of ATR and Chkl by the ARF tumour suppressor. EMBO J 2005;24:1157-69.

31. Pikarsky E, Porat RM, Stein I, et al. NF- $\kappa B$ functions as a tumour promoter in inflammation-associated cancer. Nature 2004;431:461-6.

32. Greten FR, Eckmann L, Greten TF, et al. Ikk $\beta$ links inflammation and tumorigenesis in a mouse model of colitis-associated cancer. Cell 2004;118:285-96. 
Research Paper

\section{EGFR-Dependent Downregulation of Bim in Epithelial Cells Requires MAPK and PKC- $\delta$ Activities}

\section{Marlene R. Quadros ${ }^{1}$ \\ Sharon Connelly 1 \\ Csaba Kari ${ }^{1}$ \\ Marc T. Abrams ${ }^{2}$ \\ Eric Wickstrom ${ }^{2}$ \\ Ulrich Rodeck ${ }^{1, *}$}

Departments of 'Dermatology and Cutaneous Biology and ${ }^{2}$ Biochemistry and Molecular Pharmacology; Thomas Jefferson University; Philadelphia, Pennsylvania USA

*Correspondence to: Ulrich Rodeck; Department of Dermatology and Cutaneous Biology; Thomas Jefferson University; $233 \mathrm{~S}$. 10th Street; BLSB 319; Philadelphia, Pennsylvania 19107 USA; Tel.: 215.503.5622; Fax: 215.503.5622; Email: Ulrich.Rodeck@mail.tju.edu

Received 10/18/05; Accepted 02/06/06

Previously published online as a Cancer Biology \& Therapy E-publication http://www.landesbioscience.com/iournals/cbt/abstract.php?id =2567

\section{KEY WORDS}

Bim, EGFR, apoptosis, anoikis, PKC- $\delta$, MAPK, keratinocytes, squamous cell carcinoma

\section{ABBREVIATIONS}

EGFR

MAPK

PKC- $\delta$

IGFR1

PI-3 kinase

MEK

ILK

FAK
epidermal growth factor mitogen activated protein kinase protein kinase C-delta insulin-like growth factor receptor 1 phosphatidylinositol 3-kinase mitogen activated protein kinase kinase integrin linked kinase focal adhesion kinase

\section{ACKNOWLEDGEMENTS}

We thank Dr. N. Fusenig and Dr. J. Rheinwald for providing cell lines. This work was supported by grants from NIH-NCI (CA81008 to U.R.), the Department of Defense (DAMD17-02-1-0216 to U.R.) and the Department of Energy (63055 to E.W.).

\section{ABSTRACT}

Activation of the epidermal growth factor receptor (EGFR) provides a measure of protection to immortalized epidermal keratinocytes (HaCaT cells) against apoptosis induced by diverse cellular stressors. This effect is due, in part, to sustained MAPK-dependent $\mathrm{Bcl}-\mathrm{x}_{\mathrm{L}}$ expression. Here, we report a second EGFR/MAPK-dependent signaling event that protects HaCaT cells against apoptosis incurred during forced suspension culture (anoikis). This pathway targets Bim, a pro-apoptotic BH3-only Bcl-2 family member. Bim expression was functionally relevant to $\mathrm{HaCaT}$ cell survival as demonstrated by partial protection against anoikis provided by siRNA-induced Bim downregulation. Growth factor starvation of attached and suspended cells was associated with enhanced Bim expression whereas EGFR activation reduced Bim expression by inducing Bim phosphorylation and proteasomal degradation. EGFR-dependent Bim phosphorylation required MAPK activation. Furthermore, PKC- $\delta$ activity contributed to both MEK/MAPK phosphorylation and Bim phosphorylation as demonstrated using both pharmacological inhibitors of PKC- $\delta$ and siRNA-mediated PKC- $\delta$ knockdown. In addition to HaCaT cells, EGFR activation supported survival and induced Bim phosphorylation in several squamous carcinoma cell lines in a strictly MAPK-dependent fashion. These results establish that EGFR activation attenuates susceptibility of immortalized and malignant keratinocytes to apoptosis by post-translational control of Bim-EL expression through a pathway requiring PKC- $\delta$ and MEK/MAPK activation.

\section{INTRODUCTION}

Environmental cues constitute an important organizing principle in multicellular organisms not only during embryogenesis but throughout life. In recent years it has become obvious that external control of cellular physiology entails at least three types of signals, i.e., soluble factors such as hormones, growth factors or cytokines, activation of cell/cell adhesion receptors and, adhesion to extracellular matrix (ECM). The crucial importance of ECM in maintaining epithelial cell physiology is underlined by the fact that such cells will die by apoptosis when matrix attachment is denied in a process named 'anoikis'. ${ }^{1}$ This mechanism is thought to avert dissemination of epithelial cells to inappropriate sites, most notably during the metastatic process. This concept has led several groups of investigators to study mechanisms by which epithelial cells may avoid apoptosis upon losing contact with their physiological matrix. Different mechanisms have been described including enhanced expression and function of elements of the signal transduction machinery usually activated by integrins, i.e., Fak ${ }^{2}$ and Ilk. ${ }^{3,4}$ Perhaps not surprisingly, receptor tyrosine kinases with protooncogenic properties have similarly been implicated in resistance to anoikis. Two well-studied examples in this class of anoikis inhibitors are the receptor for insulin-like growth factor 1 (IGFR1) 5 and the epidermal growth factor receptor (EGFR). ${ }^{6}$ Both receptors have been shown to affect the balance of members of the Bcl-2 family of apoptosis regulators in favor of an anti-apoptotic phenotype. For example, EGFR activation supports expression of the anti-apoptotic $\mathrm{Bcl}_{-} \mathrm{x}_{\mathrm{L}}{ }^{6,7}$ and has been reported in certain cell types to cause phosphorylation of pro-apoptotic Bad associated with functional inactivation of its pro-apoptotic properties. ${ }^{8}$

Recently, another pro-apoptotic Bcl-2 family member (Bim) has been implicated in regulation of cell death in several cell types. Bim was initially identified as a Bcl-2 binding protein. ${ }^{9}$ Subsequent studies showed that Bim, a BH3-only Bcl-2 relative, plays an essential pro-apoptotic role in activation-induced T lymphocyte death. ${ }^{10,11}$ Mice lacking Bim expression accumulate immune cells of various lineages associated with the late development of autoimmune disorders. Reginato et al. ${ }^{12}$ recently showed that forced suspension culture 
of immortalized mammary epithelial cells is associated with increased Bim expression that can be counteracted by EGF treatment. Furthermore, siRNA-mediated Bim downregulation leads to partial rescue of these cells from anoikis highlighting the functional relevance of Bim in this process.

Here we describe that Bim expression in immortalized human keratinocytes ( $\mathrm{HaCaT}$ cells) is similarly regulated by EGFR activation and is functionally relevant to cell survival in the absence of matrix attachment. Specifically, we observed that reduction of Bim expression by siRNA partially protects $\mathrm{HaCaT}$ keratinocytes form cell death in suspension culture. Furthermore, we describe a molecular mechanism by which EGFR activation counteracts Bim expression and proapoptotic function. Specifically, in attached and suspended epidermal cells, EGFR activation downregulates Bim expression by inducing Bim phosphorylation and proteasomal degradation. This phenomenon rested on EGFR-dependent MEK/MAPK activation. Furthermore, we demonstrate that PKC- $\delta$ activity is a necessary prerequisite for MAPK-dependent Bim phosphorylation and acts upstream of MEK/MAPK activation.

\section{MATERIALS AND METHODS}

Materials. Properties of the EGFR antagonistic mAb 425 have been described earlier. ${ }^{13,14}$ The MEK inhibitors PD 98059 and U0126, PI3-kinase inhibitor LY294002, the JAK-2 inhibitor AG 490, the JNK inhibitor I, the p38 MAPkinase inhibitor SB203580 and the AG1478 tyrphostin were purchased from Calbiochem-Novabiochem (San Diego, CA). The Src inhibitor PP1 and the PLC $\gamma$ inhibitor U73122 were purchased from either Calbiochem or Biomol (Plymouth Meeting, PA). The PKC $\alpha / \beta$ inhibitor Gö6976 and the PKC $\delta$ inhibitor rottlerin were purchased from Biomol. Antibodies to Bim and Bad were purchased from Calbiochem. Antibodies to PKC $\delta$ were purchased from Santa Cruz Laboratories (Santa Cruz, CA), and antibodies to $\alpha$-tubulin from Oncogene (LaJolla, CA). Antibodies to p42/44 MAPK, phospho-MAPK and phospho-MEK1/2 were purchased from Cell Signaling Technology (Beverly, MA) or Santa Cruz Biotechnology. Hemagglutinin tag antibodies were purchased from Covance (Richmond, CA).

Cell lines. Primary human keratinocytes, immortalized HaCaT keratinocytes and squamous carcinoma cell lines SCC 9, SCC 12, FaDu and, A431 were maintained in culture as described earlier. ${ }^{15,16}$ SCC 9, SCC 12 and, $\mathrm{FaDu}$ cells were kindly provided by Dr. James Rheinwald, Boston, MA, and $\mathrm{HaCaT}$ cells conditionally expressing constitutively active MEK-1 (pCEPTetP-GIC-MKK1) were described earlier. ${ }^{17}$

Cell culture conditions and forced suspension culture. For treatment with inhibitors, cells were seeded at subconfluency in a serum-free medium formulated for keratinocyte culture (Keratinocyte-SFM; GIBCOBRL, Carlsbad, CA). After attachment, medium was replaced with KeratinocyteSFM (supplemented with $0.2 \%$ BSA-FAF) that lacked any protein growth factors (base medium) unless noted otherwise for at least $12 \mathrm{~h}$. Two hours prior addition of EGF, inhibitors were added directly into the culture medium. EGF was then added for $15 \mathrm{~min}$ and cells were harvested for analysis as described below. Forced suspension culture was performed using protein-free Keratinocyte-SFM as described before. ${ }^{17}$ Rescue after forced suspension was performed by reseeding cells either into serum-containing routine culture medium for $\mathrm{HaCaT}$ or squamous carcinoma cells or fully complemented Keratinocyte-SFM for normal keratinocytes.

SiRNA treatments. Purified siRNA duplexes (siRNAs) were purchased from Dharmacon (Lafayette, CO). The siRNA sequences for targeting Bim were Bim siRNA1 (5'-AAU UGU CUA CCU UCU CGG U dTdT-3') and Bim siRNA 2 (5'- UCU GUC UGU AGG GAG GUA G dTdT-3'). The siRNA sequences for targeting PKC $\delta$ were $P K C \delta$ siRNA 1 (5'- GAU GAA GGA GGC GCU CAG dTdT-3') and PKC $\delta$ siRNA 2 (5'- GGC UGA GUU CUG GCU GGA C dTdT- 3'). Control cultures were transfected with either siRNA targeting firefly luciferase (Dharmacon) or silencer negative
control\#1siRNA (Ambion, Austin, TX). HaCaT cells were seeded in 6-well plates or $100 \mathrm{~mm}$ dishes at low confluency $(-50 \%)$ one day before transfection. Cultures were transfected with $200 \mathrm{nM}$ double-stranded siRNA using RNAifect (Qiagen, Valencia, CA). Specifically, a $20 \mu \mathrm{M}$ stock solution of double-strand siRNA was diluted with serum-free medium and mixed with $15 \mu \mathrm{l}$ of RNAifect at a ratio of siRNA to liposome of 2:3 v/v. Batch dilutions of liposomes were performed for each 6-well plate and preincubated at room temperature for $15 \mathrm{~min}$ before addition to the medium-diluted siRNA. For standard assays of activity, cells were harvested at 24, 48 and 72 hours after transfection.

Reverse transcription-polymerase chain reaction (RT-PCR). Total RNA was prepared using Trizol and reverse transcribed as described previously ${ }^{18}$ using oligo(dT) primers and AMV reverse transcriptase. Oligonucleotide primers corresponding to sequences flanking the initiation and termination codons of Bim were used (forward primer ATGGCAAAGCAACCT; reverse primer TCAATGCATTCTCCA). These primers amplify all known Bim isoforms generated by alternative splicing. ${ }^{19}$ In addition, a Bim-EL specific reverse primer was used to amplify Bim-EL sequences only (GTGCTGGGCTCCTGT). This primer covers the exon 3-4 junction present only in Bim-EL transcripts and produces a 320 bp amplimer when used with the forward primer specified above. PCR was performed using the following temperature profile: $94^{\circ} \mathrm{C}-58^{\circ} \mathrm{C}-72^{\circ} \mathrm{C}$ for 1 min each and 35 cycles. PCR was terminated using a $7 \mathrm{~min}$ extension period at $72^{\circ} \mathrm{C}$. RT-PCR products were analyzed on a $2 \%$-agarose gel with 100 bp ladder markers (Roche Diagnostics, Indianapolis, IN). PCR products corresponding in size to BIM-EL, -L, and $-S$ were reamplified, purified and subjected to diagnostic restriction enzyme analysis using Pst, Apo and PvuII, respectively.

Western blot analysis. Cells were lysed in Laemmli buffer followed by boiling for 3-5 min. Equal amounts of protein were separated by SDSPAGE and blotted onto PVDF or nitrocellulose membranes (Millipore). Membranes were blocked in blocking buffer (5\% dry milk in TBS) and then incubated with dilutions of primary antibodies in antibody buffer $(5 \%$ BSA, 0.05\% Tween 20 (Sigma Aldrich, St. Louis, MO) in TBS) followed by incubation in dilutions of HRP-conjugated secondary antibodies in the same buffers. Following antibody incubations, membranes were washed in TTBS $(0.5 \%$ Tween 20 in TBS). Signals were visualized by chemiluminescence using reagents from Pierce Chemical Co. (Rockford, IL) according to the manufaturer's instructions. After detection, blots were washed and stripped using Restore ${ }^{\mathrm{TM}}$ Western Blot Stripping Buffer (Pierce) and used for further antibody incubations.

\section{RESULTS AND DISCUSSION}

Bim expression contributes to anoikis in $\mathrm{HaCaT}$ keratinocytes. A recent report described that lack of extracellular matrix interaction induces expression of the pro-apoptotic Bcl-2 family member Bim in MCF-10A mammary epithelial cells. ${ }^{12}$ This effect contributes to anoikis, i.e., death of MCF-10A cells in the absence of matrix attachment, and is counteracted by EGFR activation. To gauge the relative contribution of Bim expression to anoikis sensitivity of immortalized human keratinocytes ( $\mathrm{HaCaT}$ cells) we compared survival of these cells in forced suspension culture upon downregulation of Bim expression using RNA interference. To downregulate Bim expression Bim mRNA was targeted using siRNA duplexes with maximal effect on Bim protein expression within $24 \mathrm{~h}$ after transfection (Fig. 1A). To allow for optimal siRNA effect, subsequent experiments were initiated $48 \mathrm{~h}$ after transfection of Bim siRNA. To ascertain cell survival after suspension culture, aliquots of suspended cells were reseeded on cell culture-treated plastic and the fraction of reattached, viable cells was assessed spectroscopically upon staining with crystal violet $24 \mathrm{~h}$ after reseeding. This analysis showed that Bim siRNA treatment was associated with partial rescue of $\mathrm{HaCaT}$ cells maintained in suspension culture in the presence of either the MEK inhibitor 


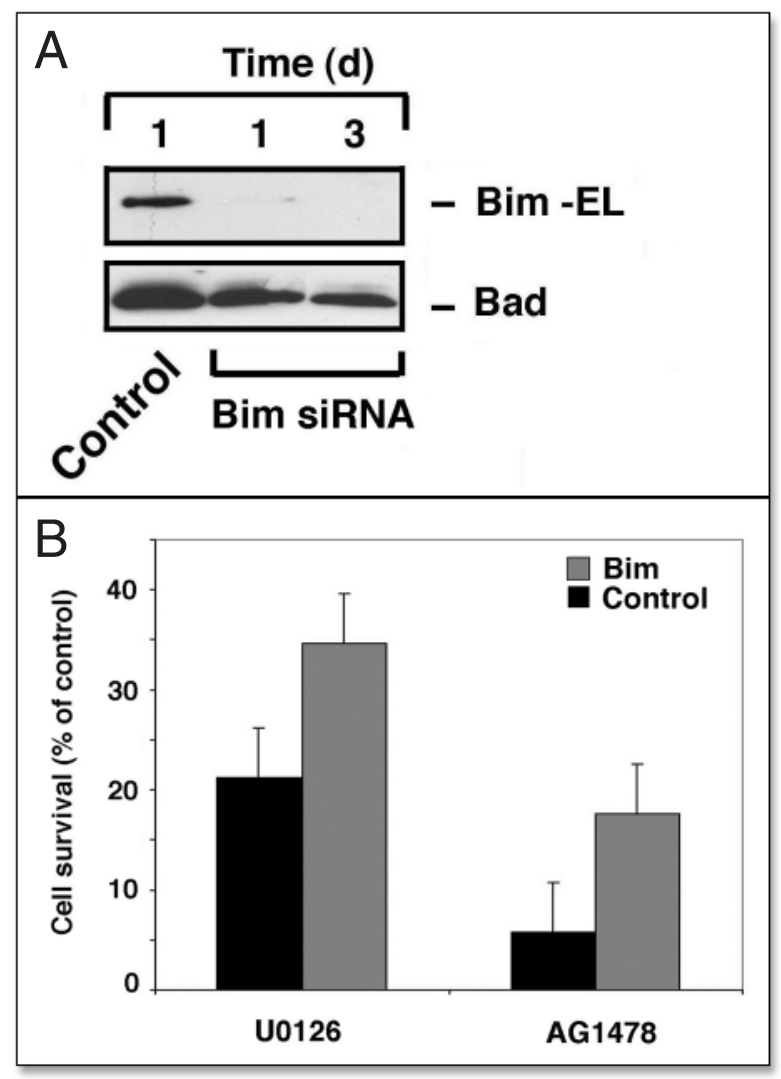

Figure 1. Expression of Bim-EL in HaCaT keratinocytes and effect of Bim downregulation on survival of $\mathrm{HaCaT}$ cells in forced suspension cultures. (A) Bim-EL expression in $\mathrm{HaCaT}$ cells transfected with siRNA targeting Bim RNA. Effects on Bim protein expression were apparent after $24 \mathrm{~h}$ of transfection. (B) Improved survival of $\mathrm{HaCaT}$ cells in forced suspension culture after Bim siRNA transfection. Forty-eight hours after transfection of either Bim or control siRNA, cells were placed in suspension culture for $48 \mathrm{~h}$ in the presence of EGF with either the EGFR inhibitorAG $1478(1 \mu M)$ or the MEK inhibitor U0126 $(10 \mu \mathrm{M})$ as indicated. Survival was assessed by spectrophotometric measurement of crystal violet staining of cells replated on tissue culture-treated plastic after $24 \mathrm{~h}$ of forced suspension culture. Staining of EGF-treated cultures in the absence of inhibitors was designated as $100 \%$.

U0126 or the EGFR selective inhibitor AG1478. Note that the increase in cell survival through Bim downregulation in inhibitortreated $\mathrm{HaCaT}$ cells represented only a fraction $(17-42 \%)$ of the survival effect achieved by EGF treatment (denoted as 100\% in Fig. 1B). The use of the MEK inhibitor U0126 in these experiments was based on our earlier findings that EGF treatment sustained MAPK phosphorylation in forced suspension culture, a phenomenon linked to increased $\mathrm{HaCaT}$ cell survival in suspension. ${ }^{17,20}$ These experiments assigned a protective role to Bim against anoikis of epidermal keratinocytes, albeit a modest one when compared to that played by EGFR activation.

Bim expression patterns in immortalized keratinocytes during growth factor starvation and forced suspension culture. Recent studies described elevated expression of Bim in various culture conditions associated with higher sensitivity to apoptosis induction. These include not only forced suspension culture of mammary epithelial cells but also growth factor deprivation of neuronal ${ }^{21}$ and hemopoietic cells. ${ }^{10,22}$ These earlier results led us to examine changes in Bim expression in $\mathrm{HaCaT}$ cells during either growth factor deprivation or forced suspension culture. To ascertain which

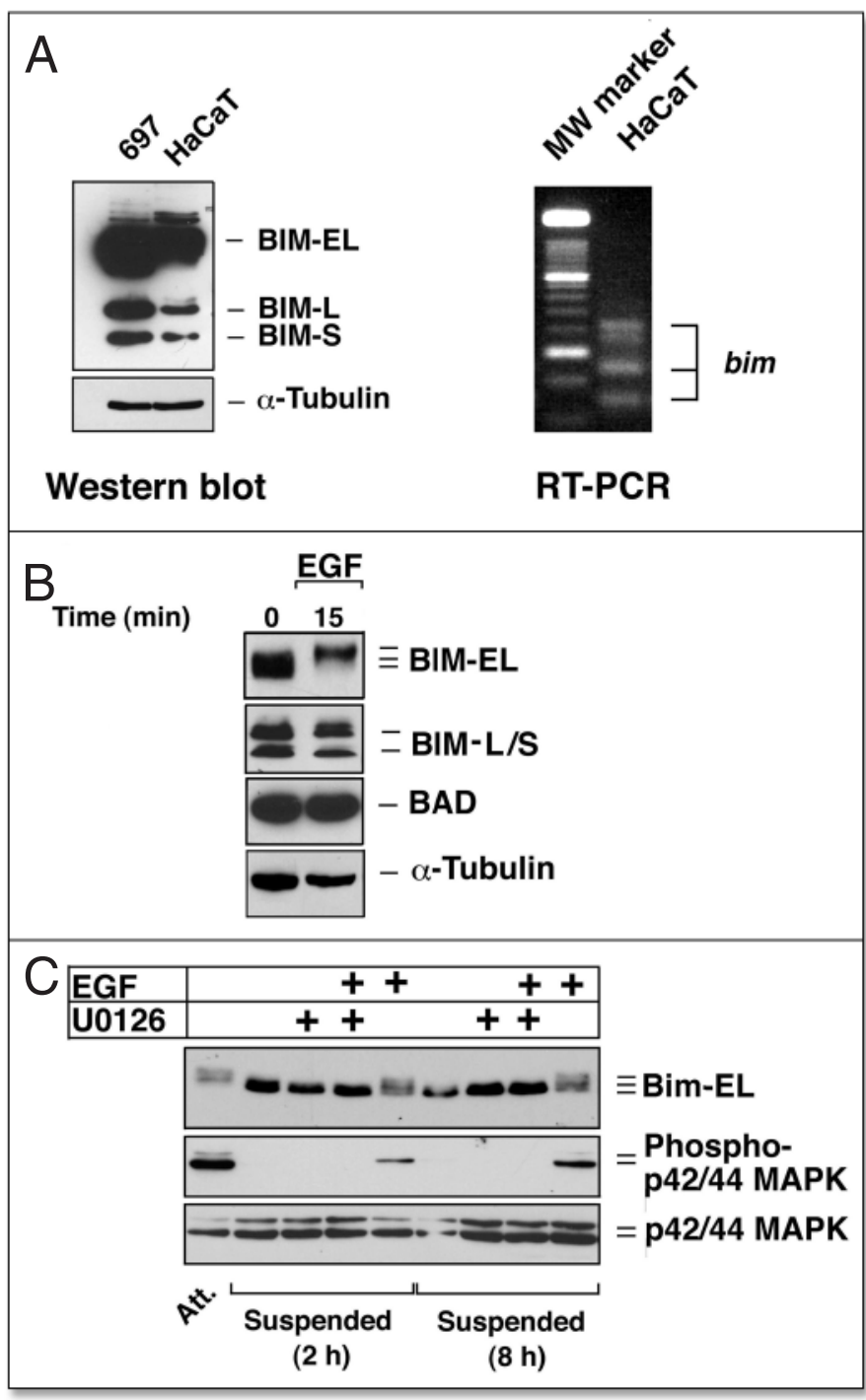

Figure 2. Expression of Bim isoforms in $\mathrm{HaCaT}$ cells and effects of EGF treatment on Bim expression in attached $\mathrm{HaCaT}$ cells (A) Expression of Bim-EL, $-L$ and, $-S$ in HaCaT cells as compared to pre-B 697 leukemia cells as assessed by Western blot analysis (left panel) and RT-PCR (right panel). (B) EGF-induced downregulation of Bim expression associated with gel retardation in growth factor-starved attached $\mathrm{HaCaT}$ cells. For control purposes, the blot was reprobed with antibodies to Bad and $\alpha$-tubulin. (C) EGF-induced gel mobility shift and downregulation of Bim expression in forced suspension cultures of $\mathrm{HaCaT}$ cells. Cells were treated throughout the observation period $(2-8 \mathrm{~h})$ with EGF $(10 \mathrm{ng} / \mathrm{ml})$ and the MEK inhibitor U0126 $(10 \mu \mathrm{M})$ as indicated. Controls are untreated attached $\mathrm{HaCaT}$ cells maintained in routine culture growth conditions. To assess efficacy of the MEK inhibitor U0126, its effect on MAPK phosphorylation is shown.

Bim isoforms are expressed in $\mathrm{HaCaT}$ cells, these experiments were initially performed in attached cells maintained in growth factor-free medium for $24 \mathrm{~h}$ (Fig. 2A). We observed similar patterns of Bim expression in $\mathrm{HaCaT}$ keratinocytes and in control 697 pre-B lymphocytes expressing high levels of Bim. Relatively strong expression of the extra long Bim isoform (Bim-EL) was contrasted by weaker signals representing the long $(\mathrm{Bim}-\mathrm{L})$ and short $(\mathrm{Bim}-\mathrm{S})$ isoforms as originally described. ${ }^{9}$ Additional weak bands may correspond to other Bim isoforms generated by additional alternative splicing events described recently. ${ }^{19}$ RT-PCR analysis indicated expression of at least three 


\begin{tabular}{|l|l|l|l|l|l|}
\hline EGF & & + & + \\
\hline MG132 & & & + \\
\hline
\end{tabular}

Figure 3. Effects of different proteosomal inhibitors on EGF-dependent Bim expression and gel mobility. (A) Attached growth-staved HaCaT cells were treated for $2 \mathrm{~h}$ with MG $132(100 \mu \mathrm{M})$ and stimulated with EGF $(10 \mathrm{ng} / \mathrm{ml})$ for $15 \mathrm{~min}$; control cells did not receive EGF. (B) Effects of phosphatasetreatment and proteasome inhibitors on Bim expression and gel migration. HaCaT cells were treated with MG $132(100 \mu \mathrm{M})$, PSI $(60 \mu \mathrm{M})$ and lactacystin $(10 \mu \mathrm{M})$ for $2 \mathrm{~h}$ and then stimulated with EGF for $15 \mathrm{~min}$. Aliquots of cell extracts were treated with calf intestinal phosphatase for $1 \mathrm{~h}$ prior to immunoblot analysis using antibodies to Bim and $\alpha$-tubulin as indicated. Phosphatase treatment abrogated reduced gel migration of Bim-EL caused byEGF treatment.

Bim transcripts encoding Bim-EL, Bim-L and, Bim-S in HaCaT keratinocytes as confirmed by diagnostic restriction enzyme analysis (Fig. 2A). In addition, we designed a separate primer set detecting BIM-EL transcripts only, which provided a robust amplification product from all RNA preparations of $\mathrm{HaCaT}$ cells (not shown). Next, we assessed Bim protein expression in growth factor-starved, attached $\mathrm{HaCaT}$ cells stimulated with EGF for 15 min (Fig. 2B). Within 15 min of EGF treatment, Bim-EL expression was reduced by $27 \%$ associated with reduced motility in SDS-PAGE gels when compared to untreated cells. By contrast, EGF treatment did not affect intensity and gel migration of the bands corresponding to Bim-L and Bim-S. Note that, in order to render the Bim-L/S bands visible (lower panel), the film was exposed considerably longer than required to detect Bim-EL expression (upper panel). Next, we assessed Bim expression in $\mathrm{HaCaT}$ cells placed in forced suspension cultures. As compared to attached cells maintained in routine culture conditions, i.e., media supplemented with fetal calf serum, $\mathrm{HaCaT}$ cells in suspension cultures performed in the absence of exogenous growth factors revealed elevated levels of Bim-EL expression (Fig. 2C). By contrast, addition of EGF attenuated Bim-EL expression at $2 \mathrm{~h}$ and $8 \mathrm{~h}$ of suspension culture accompanied by gel retardation similar to that observed in EGF-treated attached HaCaT cells. This effect was still manifest $24 \mathrm{~h}$ after initiation of suspension culture (not shown). Collectively, these results demonstrate that, in immortalized keratinocytes, EGFR activation was associated with reduced Bim-EL expression. These results extend similar findings reported by Reginato et al. ${ }^{12}$ in mammary epithelial cells to epidermal keratinocytes. However, in MCF-7 cells upregulation of Bim expression in suspension cultures was ascribed primarily to enhanced steady-state Bim mRNA levels. By contrast, we observed changes in Bim-EL expression in EGF-treated $\mathrm{HaCaT}$ cells within minutes of growth factor exposure

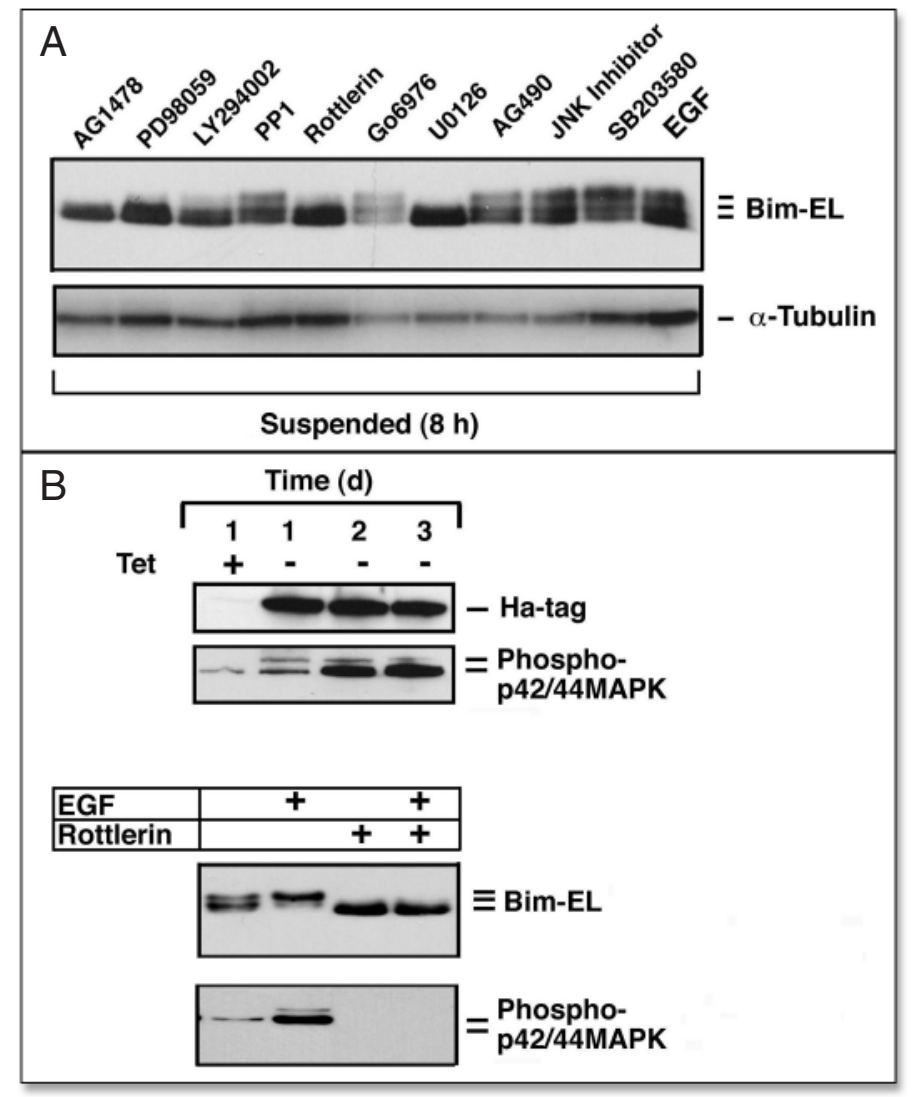

Figure 4. Effects of pharmacological inhibitors of signal transduction pathways on Bim-EL gel mobility and expression in $\mathrm{HaCaT}$ cells in forced suspension culture. (A) Effects of inhibitors of different signaling components. In addition to the MEK inhibitors U0126 (10 $\mu \mathrm{M})$ and PD98059 (50 $\mu \mathrm{M})$ the PI-3-kinase inhibitor LY294002 (10 $\mu M)$ and the PKC inhibitor rottlerin $(3 \mu M)$ inhibited EGF-induced effects on electrophoretic mobility of Bim. By contrast, Src inhibitor PP1 $(20 \mu \mathrm{M})$, Jak-2 inhibitor AG490 (100 $\mu \mathrm{M})$, JNK inhibitor $(1 \mu \mathrm{M})$, SB203580 (10 $\mu M)$, and PKC $\alpha / \beta$ inhibitor Gö6976 (5 $\mu M)$ had no effect. (B) Effect of rottlerin on Bim-EL expression in HaCaT cells conditionally expressing constitutively active MEK (Ha-MKK1-G1C). The upper panel demonstrates time-dependent transgene expression upon removal of tetracycline from the culture medium. The lower panel shows that rottlerin abrogated the EGF- and transgene-induced BIM-EL gel retardation and phosphorylation of MAPK at $48 \mathrm{~h}$ after transgene induction.

raising the question whether post-translational modification of Bim-EL played a more important role in EGFR-dependent effects on Bim expression in $\mathrm{HaCaT}$ cells.

MAPK-dependent regulation of Bim-EL expression in $\mathrm{HaCaT}$ keratinocytes. MAPK/ERK-dependent posttranslational Bim modification leading to reduced gel mobility of Bim-EL associated with reduced expression has been observed in phorbol ester-stimulated K562 leukemic cells. ${ }^{23}$ In these cells, both phenomena were linked to MAPK/ERK-dependent phosphorylation of Bim on S69 followed by ubiquitin-mediated degradation. We described previously that EGFR activation is associated with sustained MAPK phosphorylation during the early stages of suspension culture. ${ }^{17}$ Furthermore, as shown in Figure 1, $\mathrm{HaCaT}$ cells with reduced Bim expression are partially protected against anoikis in the presence of the U0126 MEK inhibitor. Taken together, these results led us to assess the effects of U0126 on EGF-induced Bim expression and gel migration. Consistent with the role of MEK-dependent MAPK phosphorylation, we observed that 


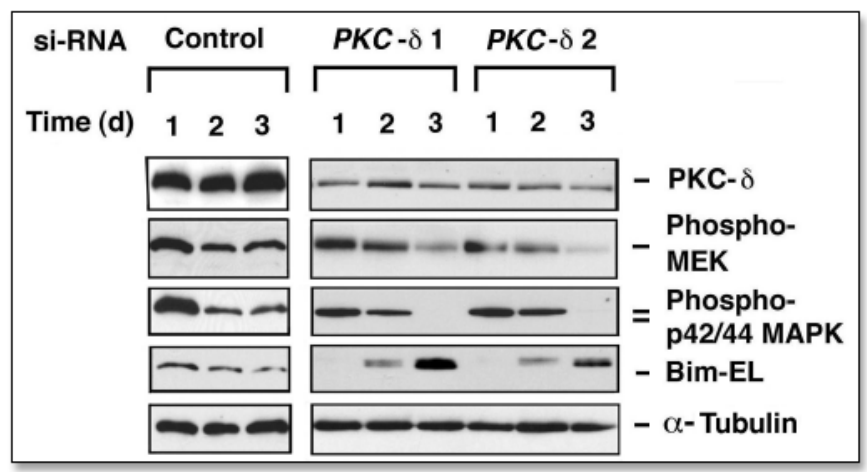

Figure 5. Effects of PKC- $\delta$ knockdown on Bim-EL expression in HaCaT cells. The effects of two different PKC- $\delta$ specific siRNA duplexes on PKC- $\delta(100 \mathrm{nM})$ expression in growing $\mathrm{HaCaT}$ keratinocytes over a period of three days after transfection. The phosphorylation of MEK, MAPK and Bim-EL expression were also determined.

U0126 abrogated both, EGFR-dependent gel retardation and reduced Bim-EL protein expression, both in suspension cultures and in growth factor-starved, EGF-stimulated cells (Figs. 2C and 4A). Very similar results were achieved when using the MEK inhibitor PD98059 (Fig. 4A). To assess whether proteasomal degradation played a role in the effects of EGF on Bim-EL expression we used the proteasome inhibitor MG132. As shown in Figure 3, MG132 did not interfere with EGF-induced gel retardation of Bim-EL but markedly attenuated the inhibitory effect of EGF on Bim-EL protein expression (Fig. 3B). Collectively, these results support the notion that, in $\mathrm{HaCaT}$ cells, MAPK-dependent Bim-EL phosphorylation targets Bim for proteasomal degradation and, thus, leads to downregulation of Bim-EL expression. By contrast, as assessed by RT-PCR using Bim-EL specific primers we did not find significant changes in Bim-EL transcript levels in the first $24 \mathrm{~h}$ of suspension culture, either in the presence or absence of EGF (not shown). In conclusion, we consider it likely that EGFR-dependent MAPK activity affects Bim protein expression in $\mathrm{HaCaT}$ cells primarily by post-translational modification as recently also described in mammary epithelial cells. ${ }^{24}$

An essential role PKC- $\delta$ in MAPK-dependent effects on Bim-EL expression. Inhibition of several other pathways previously linked to Bim phosphorylation had negligible effects on EGFR-dependent effects of Bim expression in HaCaT cells (Fig. 4A). Specifically, inhibition of JNK with a peptide inhibitor had no effect on Bim gel mobility or expression. Previous reports demonstrated Bim phosphorylation in a JNK-dependent fashion, albeit at serine/threonine residues different from those affected by MAPK, 25,26 and forced suspension culture of $\mathrm{HaCaT}$ cells resulted in substantial JNK phosphorylation relative to attached cells (Quadros MR, unpublished result). Similarly, inhibition of Src-kinases (PP1), JAK-kinases (AG490) and, p38 (SB203580) had no obvious effects on Bim-EL gel migration or expression in $\mathrm{HaCaT}$ cells. By contrast, inhibition of PI-3-kinase with LY294002 and inhibition of novel PKCs with rottlerin markedly alleviated EGF-induced Bim-EL gel retardation. Interestingly, inhibition of conventional PKCs by use of Gö6976 had no discernible effect on EGFR-dependent Bim-EL migration and expression. This result led us to investigate in more detail the role of rottlerin targets, particularly PKC- $\delta$, in regulation of Bim-EL expression. A potential role of PI-3-kinase in this phenomenon will be investigated separately.

First, we determined whether conditional overexpression of a constitutively active MEK1 construct (MKK-G1C) would obviate

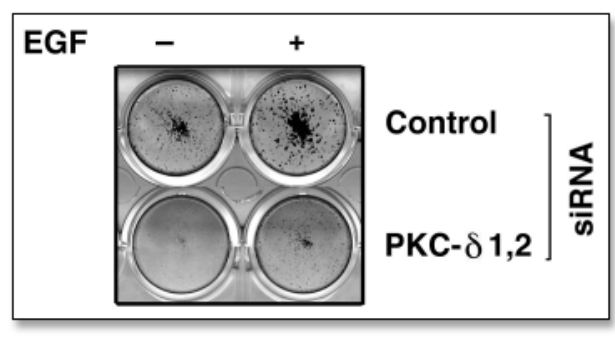

Figure 6. Decreased survival of HaCaT cells in forced suspension culture upon transfection with PKC- $\delta 1 / 2$ specific siRNA duplexes. Cell survival was assessed by replating the cells on cell culture-treated plastic after $48 \mathrm{~h}$ of forced suspension culture either in the presence or absence of EGF 110 $\mathrm{ng} / \mathrm{ml}$ ) as indicated.

the effect of rottlerin on Bim-EL expression (Fig. 4B). As shown in the upper panel of (Fig. 4B), expression of the hemagglutinin-tagged transgene was markedly induced in permissive conditions, i.e., absence of tetracycline from the culture medium. As expected, transgene expression also resulted in robust MAPK phosphorylation and partial Bim-EL gel shift even in the absence of exogenous EGF (Fig. 4B; lower panel). However, addition of rottlerin abrogated both effects, i.e., not only the Bim-EL gel shift but also MAPK phosphorylation either in the absence or presence of EGF. This result raised the issue which target of rottlerin controls MAPK phosphorylation in $\mathrm{HaCaT}$ cells.

As PKC- $\delta$ is the best-known rottlerin target, we decided to downregulate PKC- $\delta$ by RNA interference and determine the effects of this treatment on both, MAPK phosphorylation and Bim-EL gel migration and expression. As shown in Figure 5, progressive downregulation of PKC- $\delta$ expression was achieved over three days after transfection of two distinct PKC- $\delta$ specific siRNA duplexes. In contrast, control cells transfected with irrelevant siRNA revealed no significant change in PKC- $\delta$ expression in this time frame. Importantly, siRNA-mediated downregulation of PKC- $\delta$ was accompanied by marked accumulation of Bim-EL in the transfected $\mathrm{HaCaT}$ cells. Furthermore, MAPK phosphorylation progressively decreased and was negligible 3 days after transfection of $\mathrm{HaCaT}$ cells with either of the two PKC- $\delta$ targeted siRNAs. Finally, MEK phosphorylation similarly decreased upon PKC- $\delta$ siRNA treatment of $\mathrm{HaCaT}$ keratinocytes. These results reinforce the notion that PKC- $\delta$ activity controls Bim expression in $\mathrm{HaCaT}$ keratinocytes, at least in part, by modulating MEK/MAPK phosphorylation. Next, we determined the effects of siRNA-mediated downregulation of PKC- $\delta$ on MEK/ MAPK phosphorylation and Bim electrophoretic mobility upon short-term stimulation of attached $\mathrm{HaCaT}$ cells with EGF. In this setting, PKC- $\delta$ downregulation had only a moderate effect on MAPK phosphorylation and no measurable effect on Bim gel retardation and expression (results not shown). It seems possible that the partial downregulation of PKC- $\delta$ by siRNA treatment is not sufficient to block MAPK and Bim phosphorylation upon short-term EGF treatment whereas treatment with rottlerin is.

If PKC- $\delta$ activity is required for maintaining steady-state MAPK phosphorylation in $\mathrm{HaCaT}$ cells, abrogating PKC- $\delta$ expression should compromise $\mathrm{HaCaT}$ cell survival in forced suspension cultures. We chose to address this question in suspension cultures because MAPK activity is not rate-limiting to $\mathrm{HaCaT}$ cell survival in the attached state. ${ }^{17}$ To maximize the siRNA effect we used a mixture of PKC- $\delta 1$ and PKC- $\delta 2$ siRNAs to transfect $\mathrm{HaCaT}$ cells followed by $48 \mathrm{~h}$ of forced suspension culture in the presence and absence of 


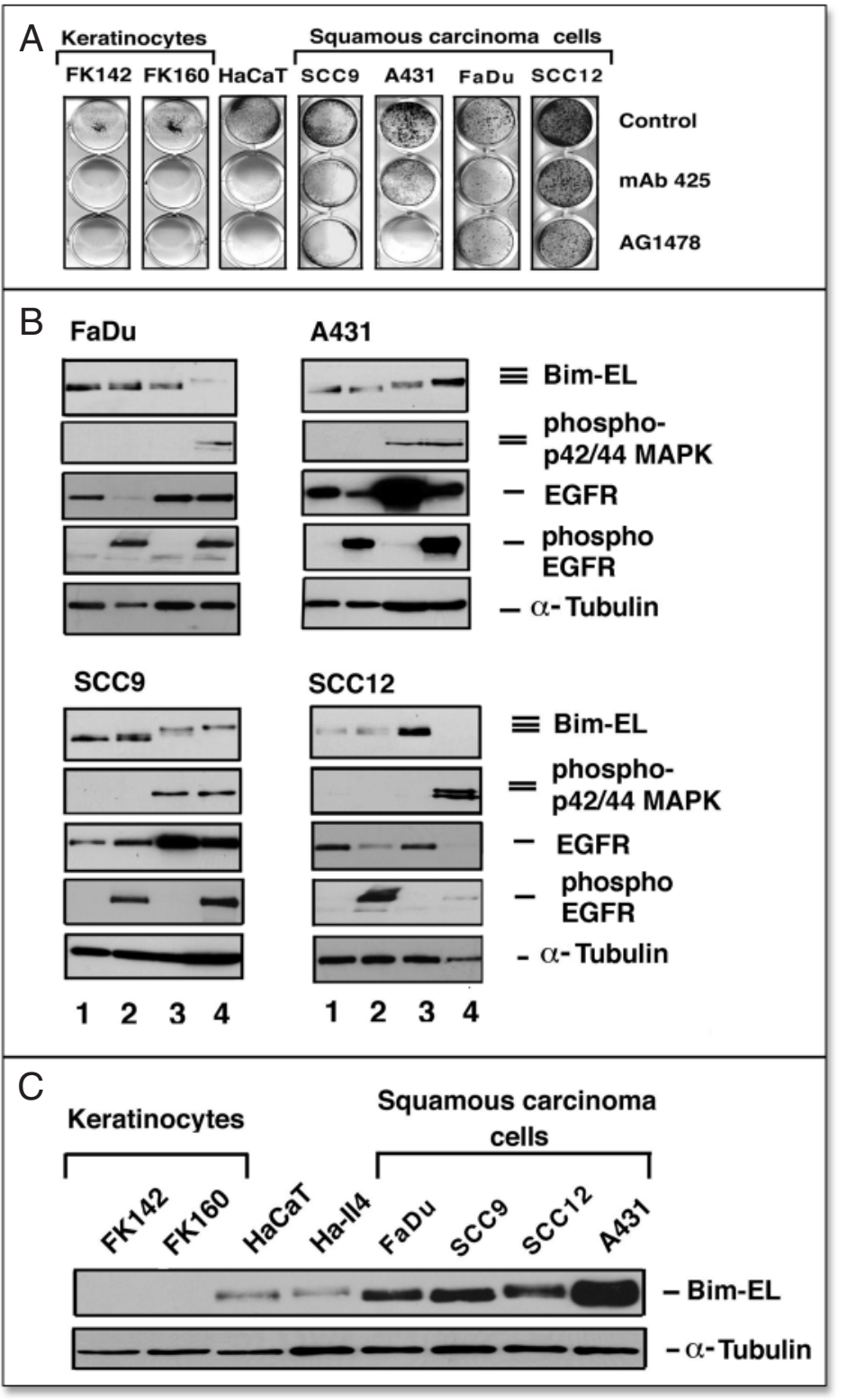

Figure 7. Anoikis sensitivity and regulation of Bim-EL expression in keratinocytes representing different stages of squamous cell carcinoma progression. (A) Effect of EGFR blockade by either EGFR antagonistic antibody $425(10 \mu \mathrm{g} / \mathrm{ml})$ or EGFR tyrosine kinase inhibitor AG1478 (10 $\mu \mathrm{M})$ on survival of normal keratinocytes, immortalized keratinocytes (HaCaT) and SCC lines in suspension. Cells were reseeded after $48 \mathrm{~h}$ of suspension culture on tissue culture-treated plastic and surviving, reattached cells were stained $24 \mathrm{~h}$ after reseeding. (B) Modulation of Bim-EL expression and gel mobility by EGFR activation in SCC lines. Attached, growth factor-starved cells (lane 1) were stimulated with EGF (2-4) for $15 \mathrm{~min}$ in the presence or absence of either AG1478 (lane 2) or U0126 (lane 3). (C) Bim-EL expression in growth factor-starved, attached normal and malignant epithelial cell lines. Note absence of signal in normal keratinocyte cell extracts.

EGF. Cell survival was assayed by reseeding cells on cell culturetreated plastic and staining of reattached cells with crystal violet 24 $\mathrm{h}$ after reseeding. These experiments showed that siRNA-mediated downregulation of PKC- $\delta$ markedly reduced the number of cells that could be rescued following forced suspension culture when compared to mock-transfected cells (Fig. 6). Thus, PKC- $\delta$ activity not only modulates MAPK phosphorylation but also supports survival of $\mathrm{HaCaT}$ cells in suspension culture. This result is consistent with previous reports that PKC- $\delta$ activity supports the RAS/RAF/MEK/ MAPK axis in cells as diverse as COS-1 and MCF-7. ${ }^{27-29}$

In keratinocytes, however, a wealth of previous evidence has implicated PKC- $\delta$ in the differentiation process ${ }^{30,31}$ and even in apoptosis induction; ${ }^{32-34}$ most of these previous studies were performed by characterizing the effects of deregulated PKC- $\delta$ activity on keratinocyte biology. To reconcile these apparently divergent results, we suggest that PKC- $\delta$ may serve a dual role in regulating apoptosis susceptibility of keratinocytes depending on activity levels. Whereas we observed that a moderate level of PKC- $\delta$ activity serves an anti-apoptotic role, elevated PKC- $\delta$ activity during keratinocyte differentiation may occur as a consequence of caspase activation and amplify the apoptotic process. ${ }^{35,36}$

Regulation of Bim-EL expression in normal keratinocytes and squamous carcinoma cells. To ascertain whether Bim-EL regulation as observed for $\mathrm{HaCaT}$ cells was shared in cells representing different stages of squamous cell carcinoma progression, we tested several normal primary keratinocyte cultures and squamous carcinoma cell lines. To varying degrees, all of these cell lines revealed accelerated rates of anoikis upon EGFR blockade as determined by their ability to reattach and grow after protracted culture $(24-48 \mathrm{~h})$ in the anchorage-independent state (Fig. 7A). As expected, the transformed cell lines exhibited a tendency towards increased survival when compared to normal keratinocytes or $\mathrm{HaCaT}$ cells. As in $\mathrm{HaCaT}$ cells, EGF treatment led to robust MAPK phosphorylation in all SCC lines accompanied by Bim-EL gel shift (Fig. 7B). In fact, we observed a strict correlation between MAPK phosphorylation and Bim gel shift in these cells consistent with an obligatory role of MAPK activation in Bim phosphorylation in this cell type. It should be noted, however, that in one of the four cell lines tested (A431), Bim-EL gel shift was not associated with reduction in expression. Interestingly, in contrast to $\mathrm{HaCaT}$ cells and the SCC lines tested, two normal keratinocyte strains expressed markedly less Bim, not detectable by Western blot analysis under the conditions chosen (Fig. 7C). We conclude that Bim-EL expression is negatively regulated by EGFR activation in 3 of 4 cell lines representing the full range of squamous cell carcinoma progression. For reasons unknown, however, Bim-EL expression appears to be substantially higher in malignant as compared to normal cultured cells in this lineage.

In conclusion, this study demonstrates that, as in mammary epithelial cells, survival of immortalized and transformed keratinocytes is enhanced by downregulation of Bim through EGFR activation and MEK/MAPK phosphorylation. Furthermore, our results highlight a novel role of PKC- $\delta$ in MEK/MAPK-activation and downregulation of Bim expression in $\mathrm{HaCaT}$ keratinocytes.

References

1. Frisch SM, Francis H. Disruption of epithelial cell-matrix interactions induces apoptosis. J Cell Biol 1994; 124:619-26.

2. Frisch SM, Vuori K, Ruoslahti E, Chan-Hui PY. Control of adhesion-dependent cell survival by focal adhesion kinase. J Cell Biol 1996; 134:793-9.

3. Attwell S, Roskelley C, Dedhar S. The integrin-linked kinase (ILK) suppresses anoikis. Oncogene 2000; 19:3811-5.

4. Wang SC, Makino K, Xia W, Kim JS, Im SA, Peng H, Mok SC, Simgletary SE, Hung MC. DOC-2/hDab-2 inhibits ILK activity and induces anoikis in breast cancer cells through an Akt-independent pathway. Oncogene 2001; 20:6960-4.

5. Valentinis B, Morrione A, Peruzzi F, Prisco M, Reiss K, Baserga R. Anti-apoptotic signaling of the IGF-I receptor in fibroblasts following loss of matrix adhesion. Oncogene 1999; 18:1827-36.

6. Rodeck U, Jost M, DuHadaway J, Kari C, Jensen PJ, Risse B, Ewert DL. Regulation of $\mathrm{Bcl}-\mathrm{xL}$ expression in human keratinocytes by cell-substratum adhesion and the epidermal growth factor receptor. Proc Natl Acad Sci USA 1997; 94:5067-72.

7. Stoll, SW, Benedict M, Mitra R, Hiniker A, Elder JT, Nunez G. EGF receptor signaling inhibits keratinocyte apoptosis: Evidence for mediation by Bcl-XL. Oncogene 1998; 16:1493-9. 
8. Gilmore AP, Valentijn AJ, Wang P, Ranger AM, Bundred N, O'Hare MJ, Wakeling A, Korsmeyer SJ, Streuli CH. Activation of BAD by therapeutic inhibition of epidermal growth factor receptor and transactivation by insulin-like growth factor receptor. J Biol Chem 2002; 277:27643-50

9. O'Connor L, Strasser A, O'Reilly LA, Hausmann G, Adams JM, Cory S, Huang DC. Bim: A novel member of the Bcl-2 family that promotes apoptosis. EMBO Journal 1998; 17:384-95.

10. Bouillet P, Metcalf D, Huang DC, Tarlinton DM, Kay TW, Kontgen F, Adams JM, Strasser A. Proapoptotic $\mathrm{Bcl}-2$ relative Bim required for certain apoptotic responses, leukocyte homeostasis, and to preclude autoimmunity. Science 1999; 286:1735-8.

11. Bouillet P, Cory S, Zhang LC, Strasser A, Adams JM. Degenerative disorders caused by Bcl-2 deficiency prevented by loss of its BH3-only antagonist Bim. Dev Cell 2001; 1:645-53.

12. Reginato MJ, Mills KR, Paulus JK, Lynch DK, Sgroi DC, Debnath J, Muthuswamy SK, Brugge JS. Integrins and EGFR coordinately regulate the pro-apoptotic protein Bim to prevent anoikis. Nat Cell Biol 2003; 5:733-40.

13. Murthy U, Basu A, Rodeck U, Herlyn M, Ross AH, Das M. Binding of an antagonistic monoclonal antibody to an intact and fragmented EGF-receptor polypeptide. Arch Biochem Biophys 1987; 252:549-60.

14. Rodeck U, Herlyn M, Herlyn D, Molthoff C, Atkinson B, Varello M, Steplewski Z, Koprowski H. Tumor growth modulation by a monoclonal antibody to the epidermal growth factor receptor: Immunologically mediated and effector cell-independent effects. Cancer Res 1987; 47:3692-6.

15. McNeill H, Jensen PJ. A high-affinity receptor for urokinase plasminogen activator on human keratinocytes: Characterization and potential modulation during migration. Cell Regul 1990; 1:843-52.

16. Quadros MR, Peruzzi F, Kari C, Rodeck U. Complex regulation of signal transducers and activators of transcription 3 activation in normal and malignant keratinocytes. Can Res 2004; 64:3934-9.

17. Jost M, Huggett TM, Kari C, Rodeck U. Matrix-independent survival of human keratinocytes through an EGF receptor/MAPK-Kinase-dependent pathway. Mol Biol Cell 2001; 12:1519-27.

18. Rodeck U, Bossler A, Kari C, Humphreys CW, Gyorfi T, Maurer J, Thiel E, Mensen HD. Expression of the $w t 1$ Wilms' tumor gene by normal and malignant human melanocytes. Int J Cancer 1994; 59:78-82.

19. Marani M, Tenev T, Hancock D, Downward J, Lemoine NR. Identification of novel isoforms of the $\mathrm{BH} 3$ domain protein Bim which directly activate Bax to trigger apoptosis. Mol Cell Biol 2002; 22:3577-89.

20. Jost M, Huggett TM, Kari C, Boise LH, Rodeck U. Epidermal growth factor receptordependent control of keratinocyte survival and Bcl-xL expression through a MEK-dependent pathway. J Biol Chem 2001; 276:6320-6.

21. Whitfield J, Neame SJ, Paquet L, Bernard O, Ham J. Dominant-negative c-Jun promotes neuronal survival by reducing BIM expression and inhibiting mitochondrial cytochrome $\mathrm{c}$ release. Neuron 2001; 29:629-43.

22. Villunger A, Scott C, Bouillet P, Strasser A. Essential role for the BH3-only protein Bim but redundant roles for $\mathrm{Bax}, \mathrm{Bcl}-2$, and $\mathrm{Bcl}-\mathrm{w}$ in the control of granulocyte survival. Blood 2003; 101:2393-400.

23. Luciano F, Jacquel A, Colosetti P, Herrant M, Cagnol S, Pages G, Auberger P. Phosphorylation of Bim-EL by Erk1/2 on serine 69 promotes its degradation via the proteasome pathway and regulates its proapoptotic function. Oncogene 2003; 22:6785-93.

24. Wang P, Gilmore AP, Streuli CH. Bim is an apoptosis sensor that responds to loss of survival signals delivered by epidermal growth factor but not those provided by integrins. J BiolChem 2004; 279:41280-5.

25. Lei K, Davis RJ. JNK phosphorylation of Bim-related members of the Bcl2 family induces Bax-dependent apoptosis. Proc Natl Acad Sci USA 2003; 100:2432-7.

26. Putcha GV, Le S, Frank S, Besirli CG, Clark K, Chu B, Alix S, Youle RJ, LaMarche A, Maroney AC, Johnson EM. JNK-mediated BIM phosphorylation potentiates BAXdependent apoptosis. Neuron 2003; 38:899-914.

27. Ueda Y, Hirai S, Osada S, Suzuki A, Mizuno K, Ohno S. Protein kinase C activates the MEK-ERK pathway in a manner independent of Ras and dependent on Raf. J Biol Chem 1996; 271:23512-9.

28. Schonwasser DC, Marais RM, Marshall CJ, Parker PJ. Activation of the mitogen-activated protein kinase/extracellular signal-regulated kinase pathway by conventional, novel, and atypical protein kinase C isotypes. Mol Cell Biol 1998; 18:790-8.

29. Keshamouni VG, Mattingly RR, Reddy KB. Mechanism of 17-beta-estradiol-induced Erk1/2 activation in breast cancer cells. A role for HER2 AND PKC-delta. J Biol Chem 2002; 277:22558-65.

30. Efimova T, LaCelle P, Welter JF, Eckert RL. Regulation of human involucrin promoter activity by a protein kinase C, Ras, MEKK1, MEK3, p38/RK, AP1 signal transduction pathway. J Biol Chem 1998; 273:24387-95.

31. Efimova T, Deucher A, Kuroki T, Ohba M, Eckert RL. Novel protein kinase C isoforms regulate human keratinocyte differentiation by activating a p38 delta mitogen-activated protein kinase cascade that targets CCAAT/enhancer-binding protein alpha. J Biol Chem 2002; 277:31753-60.

32. Li L, Lorenzo PS, Bogi K, Blumberg PM, Yuspa SH. Protein kinase Cdelta targets mitochondria, alters mitochondrial membrane potential, and induces apoptosis in normal and neoplastic keratinocytes when overexpressed by an adenoviral vector. Mol Cell Biol 1999; 19:8547-58.
33. Denning MF, Wang Y, Tibudan S, Alkan S, Nickoloff BJ, Qin JZ. Caspase activation and disruption of mitochondrial membrane potential during UV radiation-induced apoptosis of human keratinocytes requires activation of protein kinase C. Cell Death and Diff 2002; 9:40-52.

34. Papp H, Czifra G, Bodo E, Lazar J, Kovacz I, Alekza M, Juhazs I, Acs P, Sipka S, Kovacs L, Blumberg PM, Biro T. Opposite roles of protein kinase C isoforms in proliferation, differentiation, apoptosis, and tumorigenicity of human $\mathrm{HaCaT}$ keratinocytes. Cell Mol Life Sci 2004; 61:1095-105.

35. Denning MF, Wang Y, Nickoloff BJ, Wrone-Smith T. Protein kinase Cdelta is activated by caspase-dependent proteolysis during ultraviolet radiation-induced apoptosis of human keratinocytes. J Biol Chem 1998; 273:29995-30002.

36. Okuyama R, Nguyen BC, Talora C, Ogawa E, de Vignano AT, Lioumi M, Chiorino G, Tagami H, Woo M, Dotto GM. High commitment of embryonic keratinocytes to terminal differentiation through a Notch1-caspase 3 regulatory mechanism. Dev Cell 2004; 6:551-62. 